\title{
Travel Patterns of Women Giving Birth in the Southern District Health Board
}

by

\section{PAULINE GRACE DAWSON}

A thesis submitted to the Victoria University of Wellington in fulfilment of the requirements for the degree of Master of Midwifery

Victoria University of Wellington

(2015) 


\section{Table of Contents}

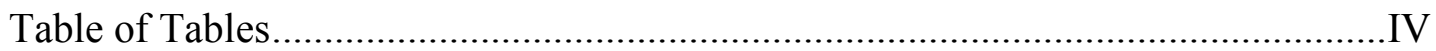

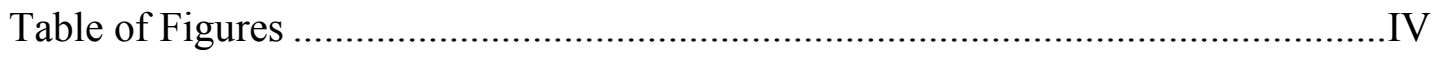

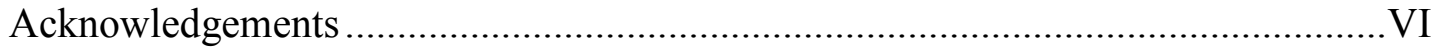

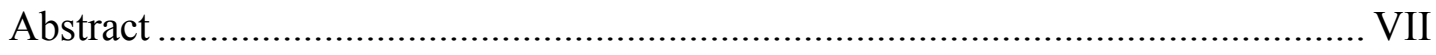

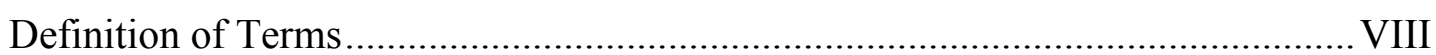

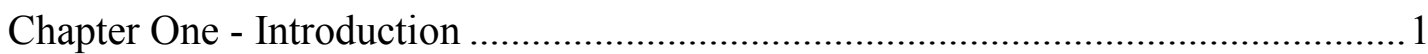

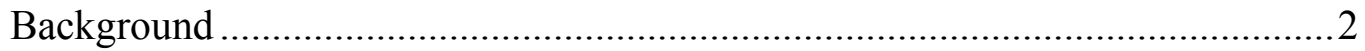

The New Zealand Context ......................................................................... 3

From Home to Hospital ...........................................................................

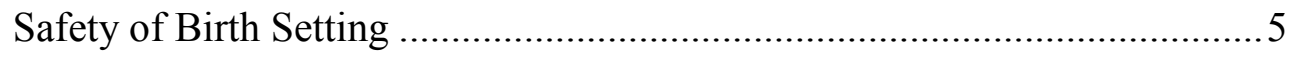

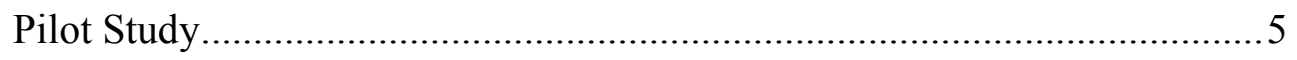

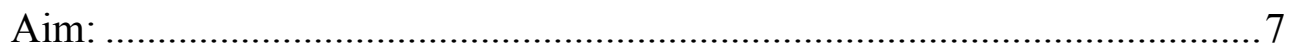

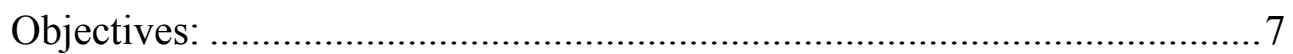

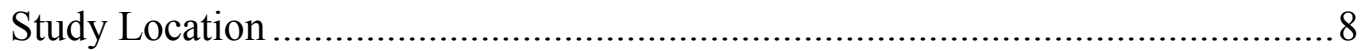

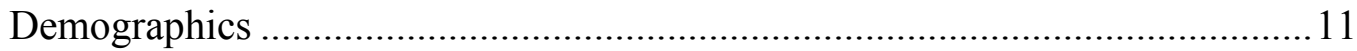

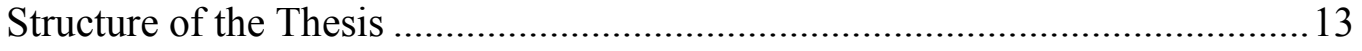

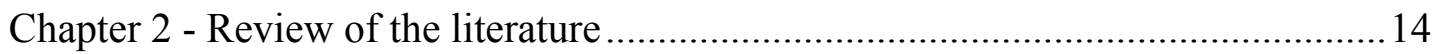

Review Methodology - organic and evolving ............................................. 14

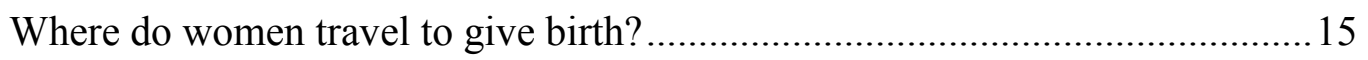

Why do women choose their place of birth? ................................................... 16

Geographic and Spatial Reasons for birthplace choice.............................. 16

Non-spatial reasons for birthplace choice .................................................22

Birthplace choice in the international literature .........................................23

Birthplace choice in New Zealand ........................................................2

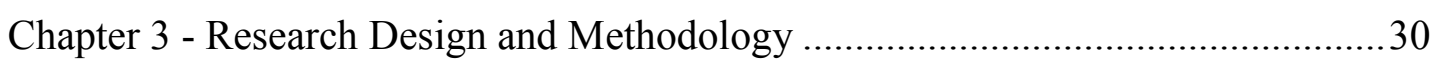

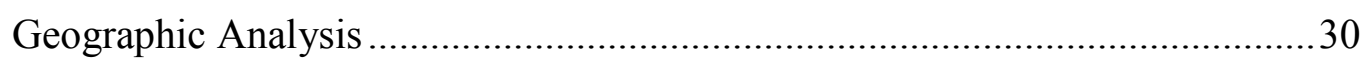

Point Data for all 2013 births in the Southern District Health Board ..........31

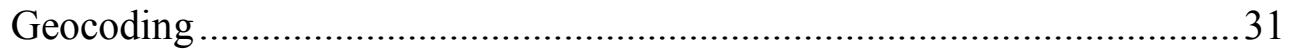

Services Areas and Road Networks ........................................................ 32

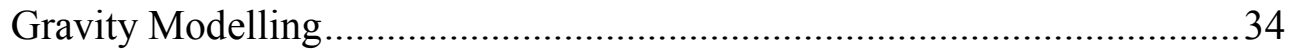

Issues and responsibilities when mapping health information ....................39

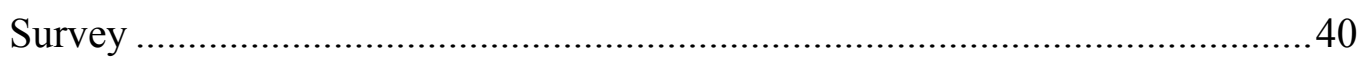

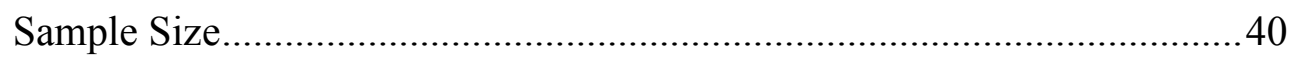

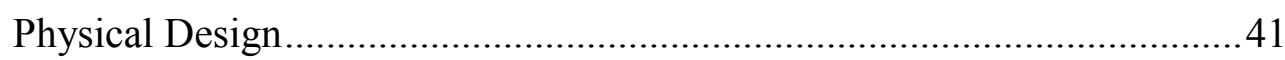

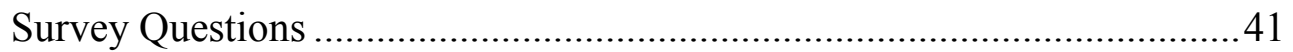




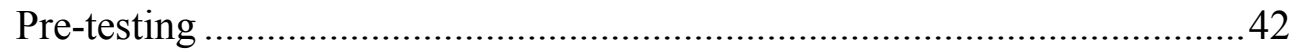

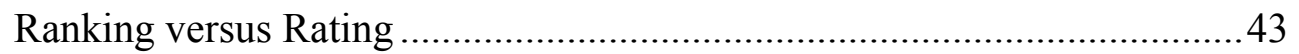

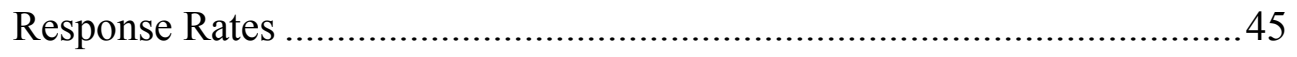

Strategies employed to improve response................................................. 46

Distribution and Collection.................................................................... 46

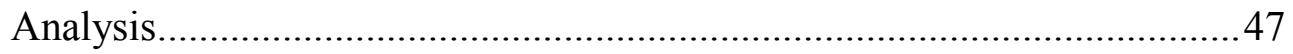

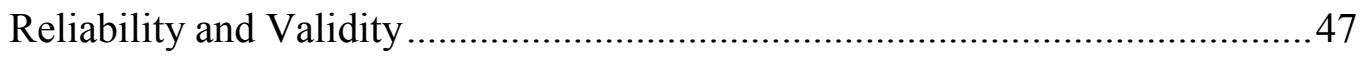

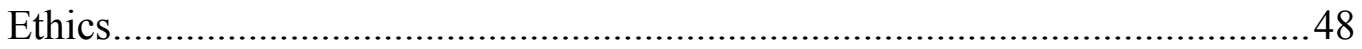

Clinical Research Approval and Scientific Peer Review .................................. 49

Treaty of Waitangi Issues and Māori Consultation ............................................50

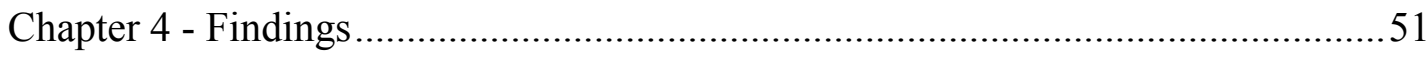

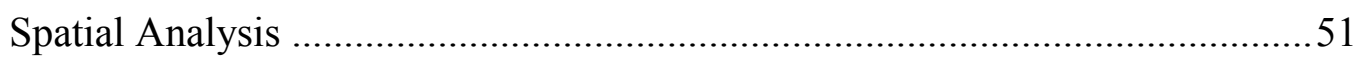

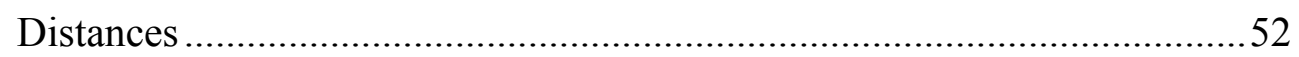

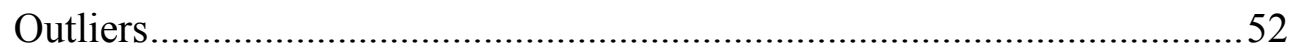

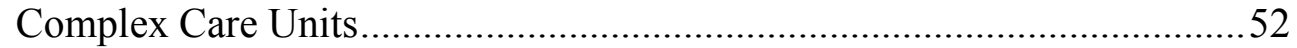

Primary Facility Potential .........................................................................

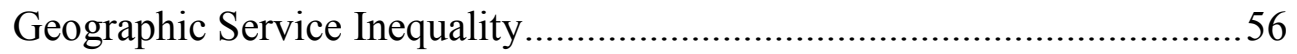

Predictive Analysis - Gravity Modelling ................................................60

Service Provision - Location/Allocation....................................................64

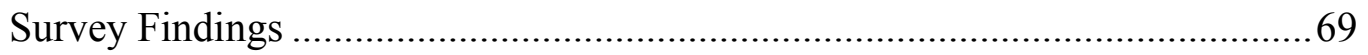

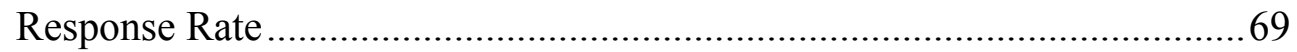

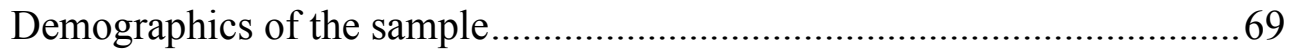

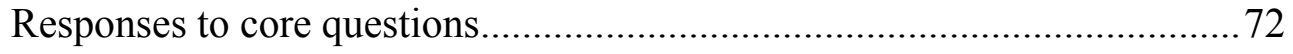

Other reasons - Question 4g - "Other" ................................................... 74

Lack of choice - Question 4c - "no other options" ................................. 75

Tension of Distance ............................................................................... 75

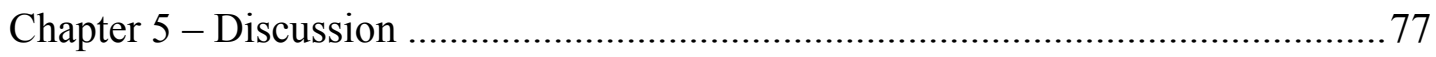

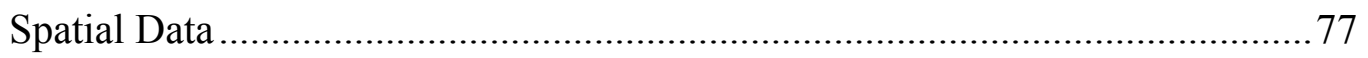

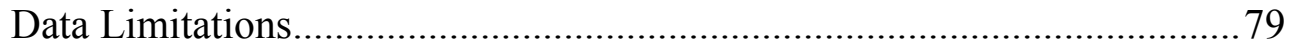

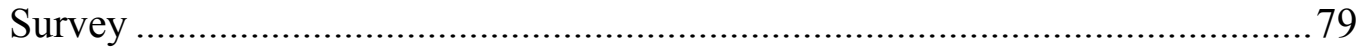

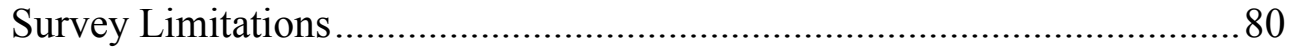

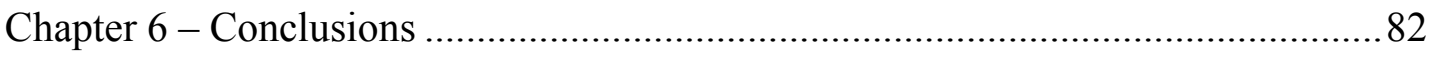

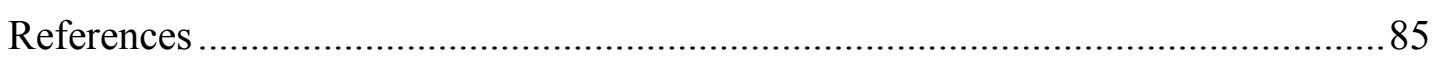

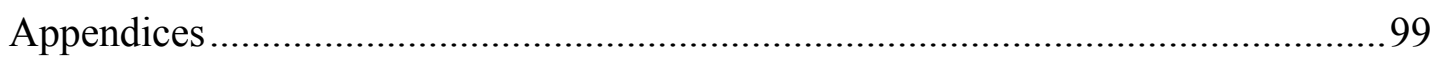

Appendix 1- Information Sheet \& Instructions...............................................99

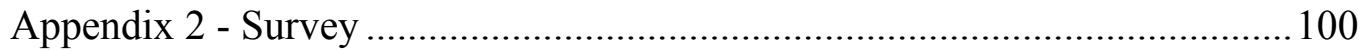

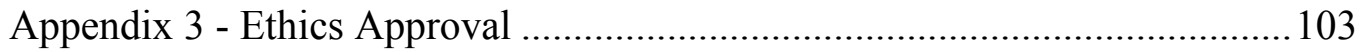


Appendix 4 - Locality Approval ................................................................ 104

Appendix 5 - Scientific Peer Review (District Health Board) ......................... 105

Appendix 6 - Ngāi Tahu Māori Consultation................................................... 106 


\section{Table of Tables}

Table 1: Southern District Health Board Population distribution by local authority...9

Table 2: Hospital births per year by facility 2010/2011 to $2012 / 2013$.

Table 3: Percentage of women giving birth by DHB of residence and ethnicity 2011

(Ministry of Health, 2014b)

Table 4: Categories of key spatial studies reviewed ................................................. 17

Table 5: International literature that informed survey questions .............................24

Table 6: New Zealand literature about Non-Spatial reasons for birthplace choice ...27

Table 7: 2013 Actual births per facility \& birthing women closest to facility Southern DHB

Table 8: Facility, 30 minute service area populations, actual births and adjusted

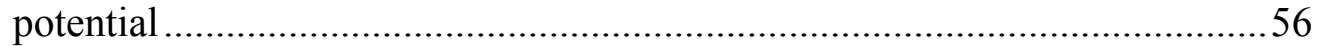

Table 9: Where women within a 30 minute drive time service area of each primary

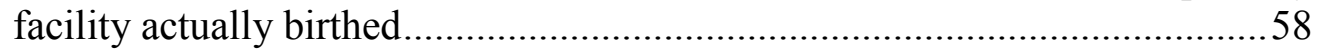

Table 10: Break Points or 'Point of Indifference' between Maternity Facilities in kilometres

Table 11: Huff Model. Probability of attending any SDHB maternity unit based on

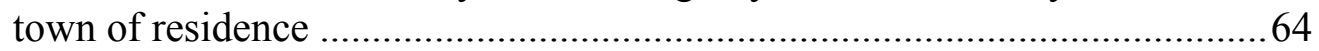

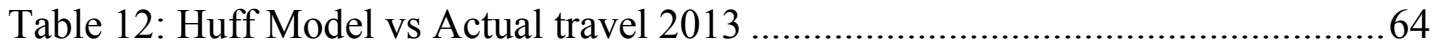

Table 13: Potential and adjusted potential births within Central Otago general........65

Table 14: Survey Response Rates (April, May, June 2014) ....................................69

Table 15: Demographic comparison of survey data and SDHB 2013 maternity data

Table 16: Descriptive statistics of the core survey questions ................................ 72

Table 17: Statistical significance of demographics variables for each survey

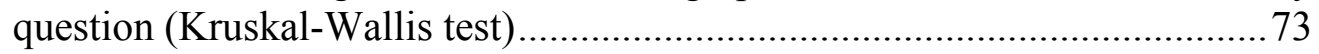

Table 18: Demographic distribution between differing birthplace (complex, primary

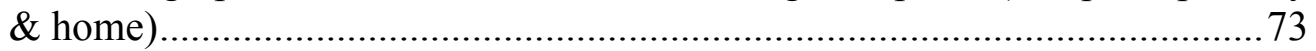

Table 19: \% of European and Māori women at each type of birthplace....................74

Table 20: Significance of change in distribution of question response across distance categories 76

\section{Table of Figures}

Figure 1: Census area units of women who birthed at Clutha Health First, Balclutha 2012 .

Figure 2: The concentration of birthing women in 2013 in Southern District Health Board by residential address (statistically significant hot spots calculated from $\mathrm{z}$ scores)

Figure 3: Southern District Health Board area, Otago/Southland regional boundaries and maternity facilities. ............................................................................ 12

Figure 4: Illustration of Gravity Modelling (Adapted from Haynes \& Fotheringham (1984))

Figure 5: Reilly's Law Example (Adapted from Rodrigue (2014)).......................... 36

Figure 6: The Huff Model Equation with retail parameters explained (D. L. Huff,

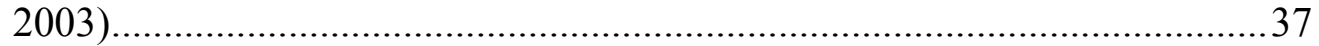

Figure 7: Rating Versus Ranking - Adapted from Alwin \& Krosnick (1985)............44 
Figure 8: Version 2 Survey Format Question 4(a) ................................................ 44

Figure 9: Final Survey Format Question 4(a) - Visual Analogue Scale.....................45

Figure 10: 30, 60 and 120 minute service areas (drive time) Invercargill and Dunedin

Complex Maternity Units ..........................................................................53

Figure 11: 30 minute service areas (drive time) for all Primary Maternity Units...... 55

Figure 12: 60 minute maternity service areas that cover Wanaka and Hawea ..........58

Figure 13: Where women who lived within 30 minutes of Queenstown gave birth in 2013

Figure 14: Where women who lived within 30 minutes of Oamaru gave birth in 2013

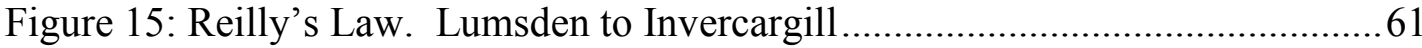

Figure 16: Reilly's Law. Alexandra to Dunedin .....................................................62

Figure 17: The women who would potentially access Queenstown Lakes Primary Maternity unit based on a 60 minute drive time and 2013 birth data............66

Figure 18: The women who would potentially access Charlotte Jean Primary Maternity unit based on a 60 minute drive time and 2013 birth data.............67

Figure 19: The women who would potentially access a new Primary Maternity unit in Wanaka based on a 60 minute drive time and 2013 birth data 67

Figure 20: The women who would potentially access a new Secondary Maternity in Cromwell unit based on a 60 minute drive time and 2013 birth data ............68

Figure 21: Means of Home and safety priority questions vs distance travelled to birth place 


\section{Acknowledgements}

This thesis could not have been completed without the help and support of many people: my colleagues in the community, at the Southern District Health Board and University of Otago; the wonderful staff at the Graduate School of Nursing, Midwifery and Health at Victoria University of Wellington and my amazing supervisor Dr. Joan Skinner. A special thanks also goes to Dr. Tony Moore, Senior Lecturer GIS, University of Otago, for reviewing a draft of this thesis. I also need to thank the birthing women who kindly and generously supported this research by completing my survey. Lastly, thanks to my wonderful friends who cheered me on from near and far, and to my long-suffering family who gifted me the time, space, and support to complete this work.

It takes a village to write a thesis.

This work was financially supported by a Health Workforce New Zealand postgraduate study grant and a Victoria University of Wellington Faculty of Humanities and Social Sciences research grant.

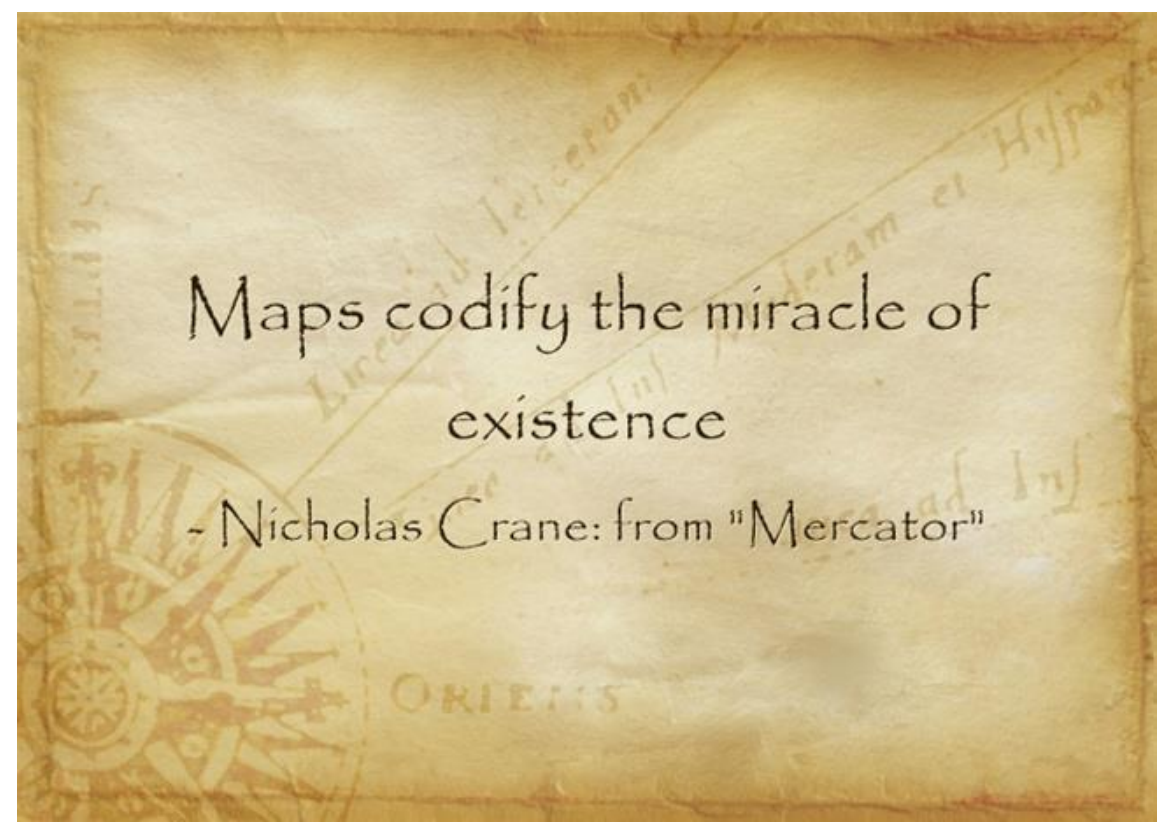




\section{Abstract}

The objective of this mixed method piece of descriptive research is to analyse travel patterns of New Zealand women relating to their selected place of birth, focusing on residents of the Southern District Health Board. It also explores the motivations of a sample of women in this area regarding their birth place choices.

Data extracted from Southern District Health Board 2013 electronic records, were analysed using geographic information system software. Spatial modelling was also conducted using this dataset. The second part of the study involved a questionnaire issued to women in Southern District Health Board maternity facilities during a three month period in 2014 .

In the analysis of 2013 data that women appeared to be by-passing smaller primary maternity units in preference for larger complex care facilities. Spatial modelling examined some possible geographic reasons for this and improved service placement was also modelled based on 2013 demand. Survey results were congruent with other similar research, in that the main reasons for women choosing birth place were a combination of seeking out a safe place whilst remaining as close to home as possible. These priorities caused a tension of distance for rural women. There was no significant statistical variance in the responses between demographic groups.

Women are prioritising safety when they choose their birth place. In a large sparsely-populated District Health Board like Southern, this results in some women making long journeys to their chosen birth place as they select complex care facilities over closer primary maternity units or home.

Keywords: Maternity care access; Geography; GIS; Birth place; Informed Choice 


\section{Definition of Terms}

Area Unit: Area units are aggregations of census meshblocks. They are nonadministrative areas that contain 3,000-5,000 people. The Ministry of Health Domicile Code is the equivalent of an area unit.

Complex Care Unit/Facility: For the purposes of this study complex care unit refers to a secondary or tertiary maternity unit.

Distance Decay: The further apart locations are, the fewer interactions they have and so are less attractive.

District Health Board: (DHB) Organisations established by the New Zealand Public Health and Disability Act 2000, responsible for ensuring the provision of health and disability services to populations within a defined geographical area.

Euclidean Distance: Straight line or "as the crow flies" distance between two points.

Geocoding: The conversion of street addresses to latitude and longitude coordinates.

Lead Maternity Carer (LMC): A provider of primary maternity services who is a general practitioner with a Diploma in Obstetrics (or equivalent, as determined by the New Zealand College of General Practitioners), a midwife or an obstetrician who has been selected by the woman to provide her primary maternity care.

Local Authority: City Council or District Council. 
Maternity Services: Any of the services described in Part C of the Maternity Services Notice Pursuant to Section 88 of The New Zealand Public Health \& Disability Act 2000.

Meshblock: A meshblock is the smallest geographic unit for which statistical data is collected by Statistics New Zealand. Meshblocks vary in size from part of a city block to large areas of rural land. Each meshblock abuts another to cover all of New Zealand, and contains approximately 80-100 people. Meshblocks aggregate to build larger geographic areas, such as area units.

Midwife: A registered health practitioner who is a Midwife, whose name is included in the register maintained by the Midwifery Council of New Zealand, and who holds a current annual practising certificate issued by that Council.

Point of Indifference: The point of indifference between two sites is the breaking point whereby one would be indifferent to accessing either site. Also known as the break point.

Primary Maternity Facility: In conjunction with the Lead Maternity Carer (LMC) or DHB Co-Ordinated Primary Midwifery care, a primary maternity facility provides primary maternity inpatient services during labour and birth and the postnatal period until discharge home.

Route Impedance /Travel Impedance: The length of a journey, for example a one hour drive has more impedance than a thirty minute drive.

Secondary Maternity Facility: Facilities where women or their babies who experience complications can receive additional maternity care involving Obstetricians and other Specialists. 
Service Area: A service area is a region that encompasses all accessible streets or roads within a specified impedance. For example, a thirty-minute service area for a facility includes all the places on streets or roads that can be reached within thirty minutes from that point.

Tertiary Maternity Facility: Such services include additional maternity care provided to women and their babies with highly complex needs who require consultation with and/or transfer of care to a multidisciplinary specialist team.

Tūrangawaewae: This is a Māori concept, literally meaning tūranga (standing place), waewae (feet). It can be translated as 'a place to stand'; Tūrangawaewae are a foundation, a place in the world, home. 


\section{Chapter One - Introduction}

Little is known about contemporary New Zealand women's birthing preferences relating their choice of birth place to geographical factors, where they live, and the journeys they make to the place they give birth. It is accepted that birthplace is frequently about clinical necessity. However, the Southern District Health Board had a $65 \%$ normal birth rate in 2011 so while a majority of women were free to choose their place of birth, most women elected to birth at large obstetric facilities. This thesis seeks to describe and analyse geographical utilisation of maternity units within the Southern District Health Board in 2013, and explore the influences behind the birthplace choices of the women in this region.

Employing concepts from human, health, and behavioural geography, and by utilizing geographic information system (GIS) mapping software, a full analysis of 3283 journeys women made to their birthplaces in the Southern District Health Board in 2013 was undertaken. Based on this data some predictive models were generated using spatial tools frequently employed in healthcare provisioning. These models illustrate the gravity or drawing power of one facility over another, and also where geographic service coverage could be improved. Maps were developed by the author using the GIS software to illustrate key points ${ }^{1}$. A cross-sectional survey of birthing women in the immediate post-partum period was then carried out over a three month timeframe in 2014 , to gain insight into the impetus behind these women's choice of birthplace.

In a publically-funded health system such as New Zealand's there is everincreasing pressure to meet the healthcare needs of a large, diverse population in an

\footnotetext{
${ }^{1}$ All maps and graphics in this thesis were created by the author unless stated otherwise
} 
economic fashion. Each District Health Board receives a share of national funding based on population size and demographic mix, and this creates specific challenges in servicing a geographically large, but thinly-populated region such as the Southern District Health Board. Understanding how women currently access and utilize maternity services is vital for planning purposes, but also for midwives working in partnership with women making informed birth place decisions during their pregnancy.

This research provides information to funders, planners, and maternity carers about where women are choosing to birth, and what factors attract them to specific services. This will inform planning for equitable provision of a safe maternity service of a level and type that meets the needs of women, and the aims and objectives of the Ministry of Health in the most cost-effective manner. Modelling of maternity unit access will also assist with future strategic planning of geographic siting of services relative to changing population densities and socio-economic factors.

These findings will also inform midwives and other maternity carers as they work with women through pregnancy and birth around birthplace decisions. Improved insight will enhance communication and evidence-based information sharing around birthplace options

\section{Background}

The objective of this study is to analyse travel patterns of New Zealand women relating to their selected place of birth, specifically in the Southern District Health Board. Limited research has been carried out in New Zealand regarding access to maternity facilities, choice of birthplace, and maternity provider 
availability in rural areas (Beere \& Brabyn, 2006; Brabyn \& Skelly, 2002; Chris Hendry, 2009). There has also been some direct work completed on why New Zealand women choose their place of birth (Davis et al., 2011; C. Grigg, Tracy, Daellenbach, Kensington, \& Schmied, 2014; Howie, 2007). However, no study has been conducted examining both spatial factors and personal preferences, alongside utilisation of, and access to, maternity facilities across both urban and rural settings.

\section{The New Zealand Context}

There are several aspects of New Zealand's maternity system that need to be described in order to contextualise this study. As described by Grigg \& Tracey (2013) and Hendry (2009) the New Zealand maternity service is unique in many ways; a major key point of difference is that the majority of women are cared for by autonomous, independent midwives. All maternity care is free for New Zealand residents, including referral to secondary and tertiary care, unless a woman opts to pay for a private obstetrician. Therefore, insurance arrangements do not dictate choice of birth place. Also, the lead maternity carer system means that in most areas, women have a choice of midwife and a range of birth place options. In 2011, 99.8\% of women in the Southern District Health Board were registered with a midwife as their Lead Maternity Carer at the time of birth (Ministry of Health, 2014c).

Women are not always restricted to booking within their District Health Board; in emergency situations however, geographic protocols are followed or women may be redirected according to neonatal intensive care bed availability e.g. a Waikato women being flown to Dunedin in the case of premature birth. For normal birth the choice of birth place is left to the woman herself in association with her chosen lead maternity carer. 


\section{From Home to Hospital}

Historically women didn't travel far to give birth, if at all. The movement from home to hospital as birthplace is an international twentieth century phenomenon, coinciding with evolving medical and obstetric knowledge. The evolution of the medicalisation of healthcare has been critiqued extensively by Illich (1976), Zola (1972), Foucault (1994), and Conrad (2008). Specific contextual histories on the changing maternity care system in New Zealand is discussed in works by Papps (1997), Banks (2000), Clark (2012), and Guilliland \& Pairman (2012). A detailed geographic view on the choice of home as birthplace and space in New Zealand by Abel \& Kearns (1991) also explores the changes in power issues around birth and is reiterated in a concise summary of power and birthplace in Anthamatten \& Hazen (2011). While these and many other critiques of the movement of birth into obstetric facilities and the potentially disempowering physical space of the maternity units e.g. "Discrimination by Design"(Weisman, 1992), Katz-Rothman (1991, 2014), and Fahy, Foureur \& Hastie (2008) have been made, currently the majority of babies in New Zealand are born within large institutional settings. Van Teijlingen \& Pitchforth (2010) compare these large complex care maternity institutions with Wal-Mart stores, and suggests that rural, community-based maternity services that are closing are being replaced by centralized obstetric facilities, which aren't just further away but operate under a completely different model of care and philosophy. In New Zealand, the Ministry of Health remains committed to rural health needs (2011) and is currently focussed on "Care Closer to Home” (Ministry of Health, 2014b) but smaller primary maternity units are continuing to close, due to centralisation and rationalisation of maternity 
services as their birth numbers continue to drop (Parkinson, 2013; Whyte \& Hyndman, 2011).

\section{Safety of Birth Setting}

Research around outcomes in various settings for example, The Birthplace in England 64,538 participant prospective cohort study (Brocklehurst et al., 2011), and also studies in the USA including Kirby (2011), also support the safety of primary birth settings for uncomplicated birth. The Brocklehurst et al (2011) study resulted in new NICE Guidelines recommending primary facilities or home for low-risk women (National Institute for Health and Clinical Excellence, 2014). The outcomes of lowrisk women in New Zealand has been favourably compared to the Birthplace England study (Dixon, Prileszky, Guilliland, Miller, \& Anderson, 2014). While women state that safety is a primary reason for their birthplace choices, this literature about the safety of settings for uncomplicated birth has not yet made an impact on societal perceptions of what is the 'usual' place of birth in many developed countries, including New Zealand. This conformity to the 'norm' of birth in large hospitals, perhaps due to an informational cascade, appears to underpin women's birthplace decision-making (Coxon, Sandall, \& Fulop, 2014).

\section{Pilot Study}

An initial pilot study of birth place data from the whole of New Zealand for 2012 was undertaken with data obtained from Statistics New Zealand (Dawson, 2013). This compared the census area unit of the women's residential address to their actual place of birth. A census area unit is an aggregate geographic area used for statistical analysis and usually has a population of 3,000-5,000 people. In urban areas these units are geographically quite small but in rural areas must sometimes be very 
large to encompass a 3,000 person population. The census area unit is also the equivalent to domicile codes used by the Ministry of Health for coding their health data.

This pilot dataset excluded home births (although a total number was provided in the data). The census area unit with the highest number of births for each hospital was listed first, with the others following in descending order. This meant that a list ranking each unit by density of birthing women for each facility was provided, and could be mapped accordingly using ArcGIS software (ESRI, 2013). As an example, Figure 1 shows the census area units that are made up of smaller meshblocks (boundaries shown) of women birthing at Clutha Health First in Balclutha in 2012. The darker the colour of the census area unit, the more women came from that area.

Figure 1: Census area units of women who birthed at Clutha Health First, Balclutha 2012

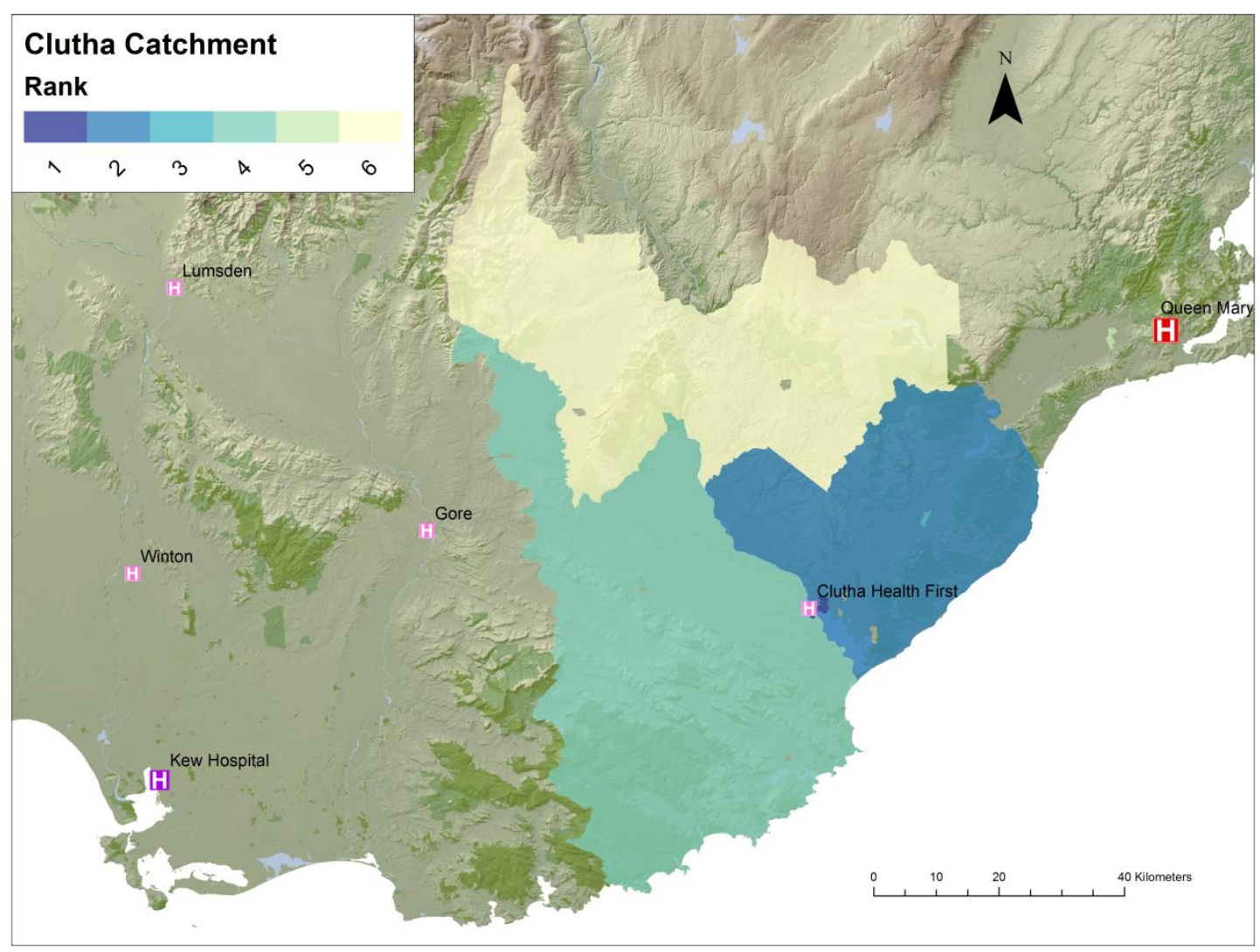


The pilot study provided a broad overview of travel patterns of birthing women nationally, across both urban and rural settings. While this data indicated generalized travel trends, the data units proved too 'coarse' for analysis of where women chose to birth, due to large geographical areas (as illustrated in Figure 2). It did suggest that women were frequently bypassing units close to their residential address, but the data was only indicative and also was unable to show why these travel decisions were being made. The pilot study findings and the questions left unanswered are the core reasons for embarking on this master's research project.

Derived from the pilot study, the aims and objectives of this research project were:

\section{Aim:}

To describe the travel patterns of birthing women in New Zealand in relation to geographical access and personal choice of birthplace, focussing on women in the Southern District Health Board in 2013/2014.

\section{Objectives:}

1. Complete a geographical analysis of women's birthplace compared to their usual residential address.

2. Review demographic, geographical, clinical, and other factors that may influence choice of birth location.

3. Complete a survey of women's reasons for choice of geographical birth place.

This thesis firstly focuses on an examination of data for the Southern District Health Board area for all facility births in 2013. Point data (longitude and latitude co-ordinates) were generated for both the women's residential address and that of 
their actual birth place. These co-ordinates enabled detailed scrutiny of maternity facility catchment and service areas and their potential "customers". A service area or catchment was defined as the geographical area surrounding a maternity facility within a specified driving time. Geographic impact and travel route impedance was also assessed. Simple route impedance is the length in time of a journey; for example, a one hour drive has more impedance than a thirty minute drive. Impedance can also be increased by an unsealed road increasing drive time, roads that are difficult to pass in winter, or routes that are demanding and therefore slower to drive due to local topography.

The final section of the study is a cross-sectional survey undertaken to gain insight into influences on birthplace choice; to try and answer why women were travelling out of their catchment areas and bypassing smaller maternity units, as indicated in the pilot study data. This survey was also distributed to the homebirth population over the same period to see why some women chose not to travel to give birth at all.

\section{Study Location}

The study was undertaken in the Southern District Health Board, an amalgamation of the Southland and Otago District Health Boards, formed in 2010. Geographically, it is now the largest District Health Board in New Zealand with a land area of over 62,356 square kilometres. Its estimated resident population of 304,260 is approximately $7.1 \%$ of the national population (Health Partners Consulting Group, 2014). There are large, sparsely-populated regions with only two main urban areas in Invercargill and Dunedin. Table 1 shows the population distribution by local authority. 
Table 1: Southern District Health Board Population distribution by local authority

\begin{tabular}{|l|r|}
\hline \multicolumn{2}{|l|}{ Southern District Health Board catchment population by local authority } \\
\hline Invercargill City & $17.20 \%$ \\
\hline Gore District & $4.00 \%$ \\
\hline Queenstown-Lakes District & $9.30 \%$ \\
\hline Rural Southland & $9.70 \%$ \\
\hline Dunedin City & $41.00 \%$ \\
\hline Central Otago & $6.20 \%$ \\
\hline Clutha District & $5.70 \%$ \\
\hline Waitaki District & $6.80 \%$ \\
\hline
\end{tabular}

Figure 2: The concentration of birthing women in 2013 in Southern District Health Board by residential address (statistically significant hot spots calculated from $\mathrm{z}$ scores)

\section{Southern DHB 2013 - residential hotspots of birthing women}

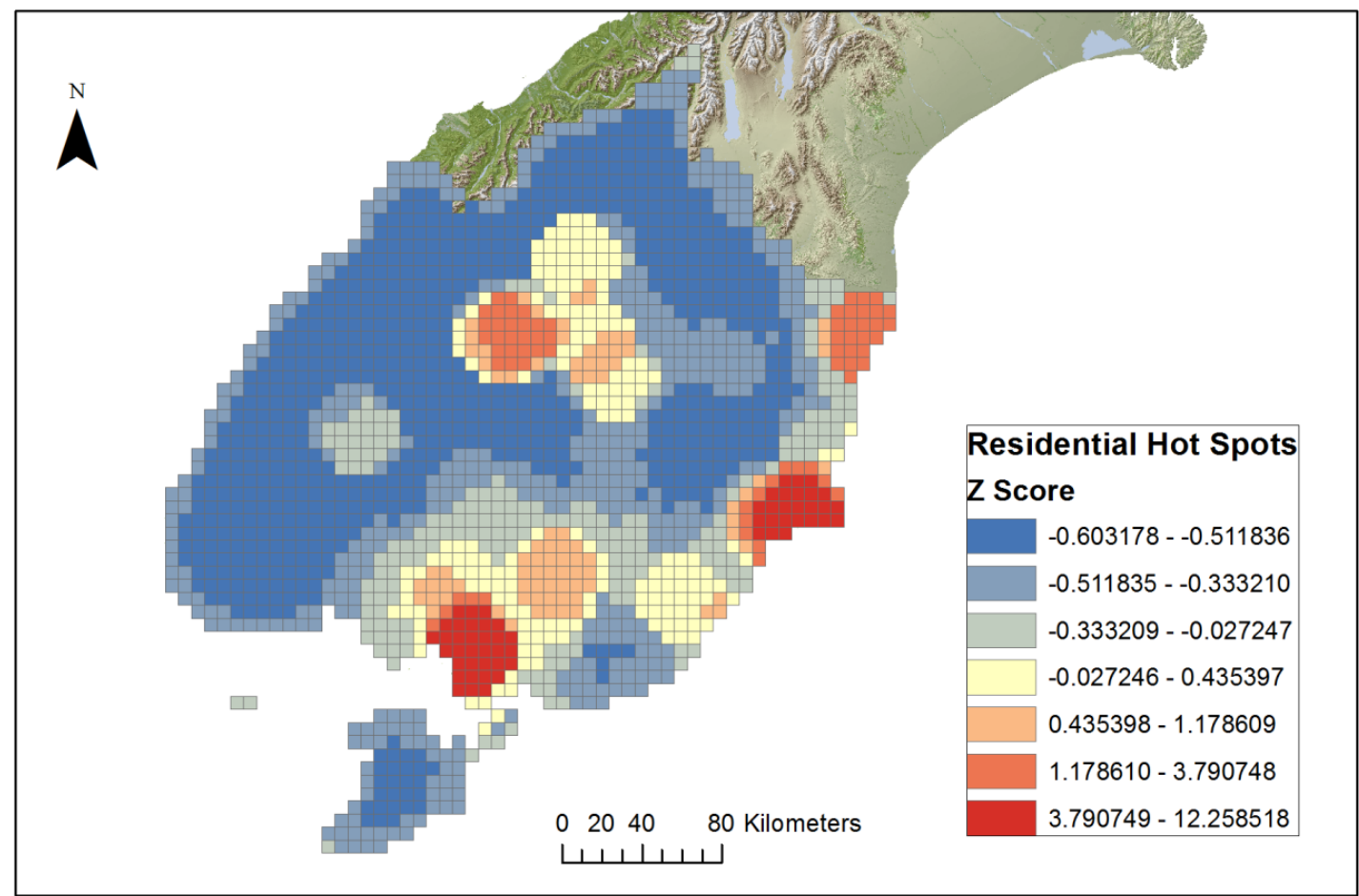

The Southern District Health Board region has a tertiary maternity unit in Dunedin (Queen Mary Maternity Centre), a secondary unit in Invercargill (Southland Hospital) and eight primary units in rural locations (see Table 2). In fact, the 
Southern District Health Board has more maternity facilities per head of population than any other District Health Board in New Zealand (Ministry of Health, 2012).

The following table (Table 2) shows births per year by facility for the years 2010/2011 - 2012/2013 (Health Partners Consulting Group, 2014, p. 106).

Table 2: Hospital births per year by facility 2010/2011 to 2012/2013

\begin{tabular}{|l|r|r|}
\cline { 2 - 3 } \multicolumn{1}{c|}{} & $\begin{array}{c}\text { Deliveries } \\
\text { per year }\end{array}$ & $\begin{array}{c}\% \text { of } \\
\text { total }\end{array}$ \\
\hline Charlotte Jean Maternity Unit & 64 & $1.9 \%$ \\
Clutha Health First & 28 & $0.8 \%$ \\
Dunedin & 1,744 & $51 \%$ \\
Gore Health Centre & 80 & $2.3 \%$ \\
Lakes District & 50 & $1.5 \%$ \\
Maniototo Health Services & 2 & $0.1 \%$ \\
Northern Southland Birthing Centre & 22 & $0.7 \%$ \\
Oamaru & 90 & $2.6 \%$ \\
Southland & 1258 & $36.8 \%$ \\
Tuatapere Maternity Hospital & 20 & $0.6 \%$ \\
Winton Birthing Centre & 34 & $1.0 \%$ \\
Elsewhere In New Zealand & 27 & $0.8 \%$ \\
\hline TOTAL & 3420 & $100 \%$ \\
\hline
\end{tabular}

(NB: Maniototo Health Services in Ranfurly is no longer a birthing centre.)

It is anticipated that examining this mixture of available maternity facilities (primary, secondary, and tertiary) may reveal patterns related to choice between differing service levels and between both rural and urban women. There may also be demographic factors involved (for example ethnicity) as suggested by Davis et al (2011); however, it is recognised that the SDHB has a comparatively homogenous birthing population.

\footnotetext{
${ }^{2}$ Women normally residing in the Southern DHB who birthed elsewhere in New Zealand
} 


\section{Demographics}

There is some variation in Southern District Health Board demographics compared to national averages, showing this district has greater homogeneity within the birthing population, particularly in relation to ethnicity (see Table 3).

Table 3: Percentage of women giving birth by DHB of residence and ethnicity 2011 (Ministry of Health, 2014b)

\begin{tabular}{|l|c|c|c|c|}
\hline & \multicolumn{4}{|c|}{ Maternal ethnicity } \\
DHB of residence & Māori & Pacific & Asian & Other \\
\hline Southern DHB & $16 \%$ & $4 \%$ & $5 \%$ & $74 \%$ \\
\hline All NZ & $25 \%$ & $11.5 \%$ & $11.5 \%$ & $52 \%$ \\
\hline
\end{tabular}

Southern women also have a lower fertility rate at 1.66 births per women compared with the national average at just over 2 (Health Partners Consulting Group, 2014).

With the amalgamation of the Southland and Otago District Health Boards in 2010, services are largely arranged around the old District Health Board margins which were similar to regional boundaries (Figure 3) e.g. Women from Queenstown would choose Invercargill for complex care services and specialist antenatal clinics at Lakes Hospital are run by Invercargill obstetricians. This master's study shows that some women do choose their birth place independently of these historic boundaries. 
Figure 3: Southern District Health Board area, Otago/Southland regional boundaries and maternity facilities.

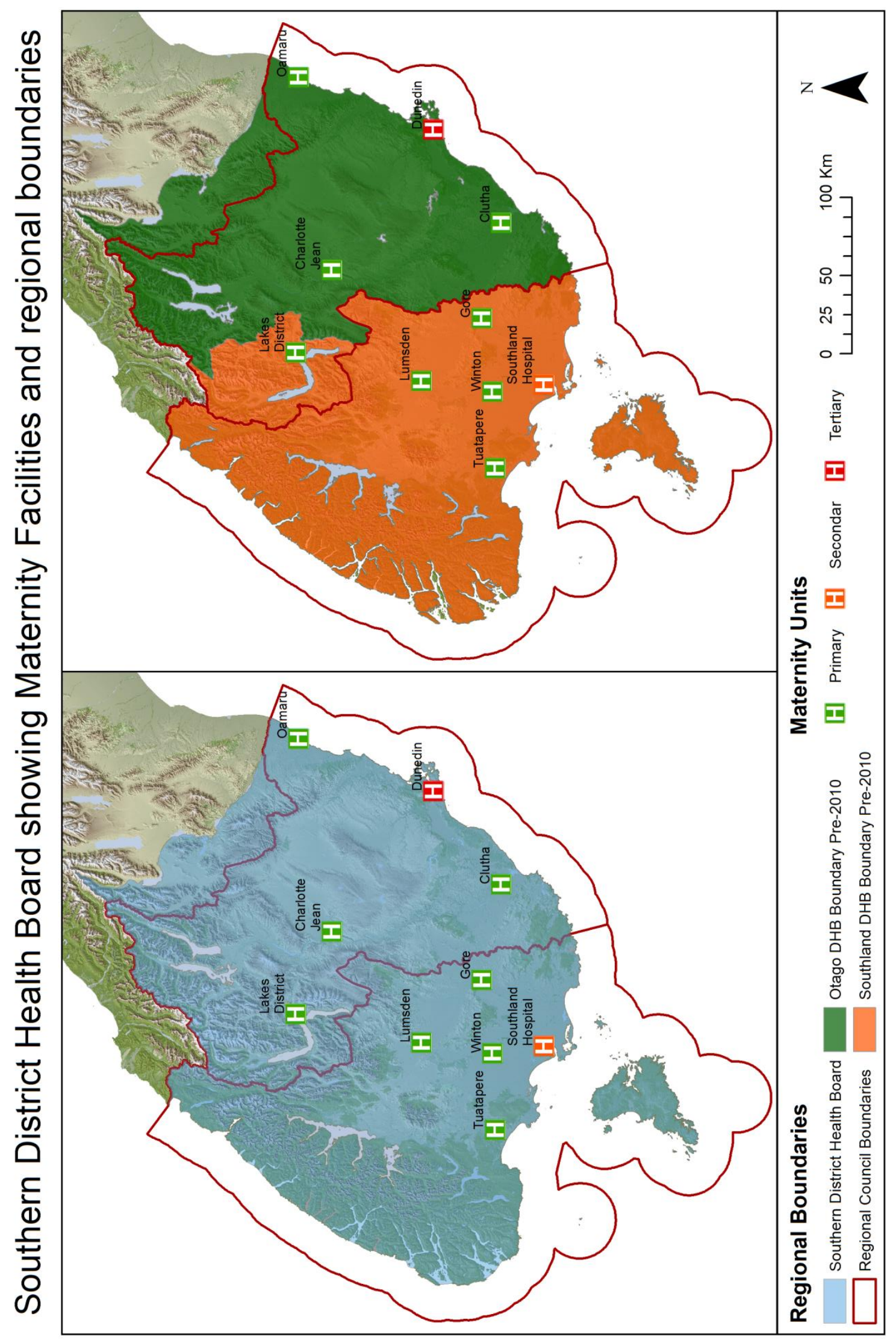




\section{Structure of the Thesis}

This thesis describes where women in the Southern District Health Board in 2013 chose to birth and the journeys they made from their homes to their birthplace. It also explores motivations behind these choices and travels via data collected by a survey. The thesis is divided into six chapters. The introductory chapter provides the background of birthplace and choice, and information about the study location. Chapter Two reviews the evidence around where women choose to birth and both geographical and more personal reasons behind birthplace choice. Chapter Three outlines the research design and methodologies used. The results of the geographic analysis, modelling and survey are presented in Chapter Four. Chapter Five discusses the findings, sets out some of the limitations of the study, and suggests areas that could be explored further. The thesis ends with Chapter Six, an overall conclusion, followed by appendices as referred to within the text. 


\section{Chapter 2 - Review of the literature}

There are two parts to the research question: where women chose to give birth; and why they made these choices. Therefore, the review of the literature was conducted along these two lines. These questions and the resulting evidence found in the literature review informed the research design, resulting in a mixed methodology of geographic techniques and a survey. The first question was addressed by reviewing the evidence on the places where women choose to give birth. The second section of the review examined the reasons why women choose these birth places. This in turn split into two separate aspects of choice: geographic and spatial reasons, including identifying ways of measuring and modelling utilisation, access and service provision that could be applied to the maternity context; and more personal and psychological motives.

\section{Review Methodology - organic and evolving}

As a starting point, relevant $\mathrm{MeSH}$ headings such as "birth place" were selected and combined with terms such as "geography", "GIS", "choice" and "New Zealand" for specificity when searching databases including CINAHL and PubMed. These terms were also used in general searches of university library databases and Google Scholar. Through this single process, the evidence addressing the two research questions diverged naturally into discrete bands reflecting factors around where women birth and the decision making processes around that.

The research strategy evolved over time in many permutations, and with one reference or link frequently leading to several others. In the same way, some themes and keywords led to others, with search terms added and refined as the search 
progressed. This technique is analogous to that described as 'pearl growing' in the literature (Ramer, 2005; Schlosser, Wendt, Bhavnani, \& Nail-Chiwetalu, 2006).

Key articles and texts were identified by their deemed relevance to each research question. Through reading titles and abstracts, using the journal database "related article" functions, and the "Suggest" facility in the Mendeley referencing software, other sources were located that may have been missed earlier. This process was repeated by assessing the reference list of all relevant texts and articles and continuously relating the literature to the thesis "where" and "why" questions. Once located and after annotation, information results were categorized into thematic groups for critique and synthesis.

\section{Where do women travel to give birth?}

From birth place statistics and the pilot study it was established that in New Zealand most women give birth in secondary or tertiary hospitals, with only a small percentage giving birth in a primary maternity facility or at home (Ministry of Health, 2013). When the literature was reviewed around this topic, it became evident little research had been carried out in developed countries relating choice of birthplace to place of residence. The key study in this area was Pitchforth, van Teijlingen, Watson et al (2009) who studied the choices made by women in remote and rural Scotland. This study also looked at why these choices were made, and followed on from a study considering the trade-offs made in the same region when accessing different models of intrapartum care (Pitchforth et al., 2008). In the latter study, the "time travelled" variable was compared to the choice of birthplace/model of care; this comparison became a crucial factor in analysing travel patterns in the current thesis research. 


\section{Why do women choose their place of birth?}

The second research question, why women chose their birthplace, diverged into two themes. The first was around the impact of spatial/geographical features on women's decision making. The second theme was of a more personal and emotional nature, including issues such as family proximity and philosophy around childbirth.

\section{Geographic and Spatial Reasons for birthplace choice}

Literature related to the spatial and geographical reasons why women might choose their birth location was sourced from a range of disciplines and other research around access to general healthcare was also reviewed (see Table 4). These sources informed the methodology for measurement and testing of access in this thesis.

Incidentally echoing van Teijlingen \& Pitchforth's (2010) ideas around service provision (as discussed in Chapter One), a body of work in health and medical geography was discovered that relates utilisation of heath care facilities to landmark theories and modelling of retail and shopping patterns (Gregory, Johnston, Pratt, Watts, \& Whatmore, 2009; Haynes \& Fotheringham, 1984; King, 1984). This gravity framework, where gravity is a relationship between size of and distance between places, is used extensively in healthcare planning when predicting utilisation and optimising facility size and location. It is founded on Tobler's First Law of Geography, which states "Everything is related to everything else, but near things are more related than distant things" (Longley, Goodchild, Maguire, \& Rhind, 2011, p. 65). 


\section{Access}

Much of this geographic research centres on the features of access. Healthcare access is defined by Penchansky \& Thomas as "the fit between the patient and the health care system" (1981, p. 127). These authors contend that access has five main dimensions: availability, accessibility, affordability, accommodation, and acceptability. While the last three factors tend to be socioeconomic factors, the first two are largely spatial.

Key studies and reference material identified relating to these aspects were drawn from a variety of disciplines and are summarised in Table 4 below.

Table 4: Categories of key spatial studies reviewed

\begin{tabular}{|c|c|c|}
\hline Title, Authors, Date & Setting & Discipline \\
\hline \multicolumn{3}{|l|}{ Spatial access and choice - Specifically Maternity Related } \\
\hline $\begin{array}{l}\text { The Use of Central Place Theory for the Location of Maternal } \\
\text { and Infant Care Projects (Fox \& Fox, 1974) - Landmark Study }\end{array}$ & $\begin{array}{l}\text { West } \\
\text { Virginia, } \\
\text { USA }\end{array}$ & $\begin{array}{l}\text { Maternity/Health } \\
\text { Geography }\end{array}$ \\
\hline $\begin{array}{l}\text { Birth places: A geographical perspective on planned home birth } \\
\text { in New Zealand (Abel \& Kearns, 1991) }\end{array}$ & New Zealand & $\begin{array}{l}\text { Maternity/Health } \\
\text { Geography }\end{array}$ \\
\hline $\begin{array}{l}\text { Choosing where to deliver: decision criteria among women with } \\
\text { low-risk pregnancies in France. (Combier et al., 2004) }\end{array}$ & France & $\begin{array}{l}\text { Maternity/Health } \\
\text { Geography }\end{array}$ \\
\hline $\begin{array}{l}\text { Providing the evidence: Geographic accessibility of maternity } \\
\text { units in New Zealand (Beere \& Brabyn, 2006) }\end{array}$ & New Zealand & $\begin{array}{l}\text { Maternity/Health } \\
\text { Geography }\end{array}$ \\
\hline $\begin{array}{l}\text { Models of intrapartum care and women's trade-offs in remote } \\
\text { and rural Scotland: a mixed-methods study (Pitchforth et al., } \\
\text { 2008) }\end{array}$ & Scotland & $\begin{array}{l}\text { Maternity/Health } \\
\text { Geography }\end{array}$ \\
\hline $\begin{array}{l}\text { Impact of maternity unit closures on access to obstetrical care: } \\
\text { The French experience between } 1998 \text { and } 2003 \text { (Pilkington, } \\
\text { Blondel, Carayol, Breart, \& Zeitlin, 2008) }\end{array}$ & France & $\begin{array}{l}\text { Maternity/Health } \\
\text { Geography }\end{array}$ \\
\hline $\begin{array}{l}\text { Planning the optimal level of local maternity service for small } \\
\text { rural communities: a systems study in British Columbia } \\
\text { (Grzybowski, Kornelsen, \& Schuurman, 2009) }\end{array}$ & Canada & $\begin{array}{l}\text { Maternity/Health } \\
\text { Geography }\end{array}$ \\
\hline $\begin{array}{l}\text { Distribution of maternity units and spatial access to specialised } \\
\text { care for women delivering before } 32 \text { weeks of gestation in } \\
\text { Europe (Pilkington et al., 2010) }\end{array}$ & Europe & $\begin{array}{l}\text { Health Geography/ } \\
\text { Geographic } \\
\text { Information } \\
\text { Systems (GIS) }\end{array}$ \\
\hline $\begin{array}{l}\text { How far?: Using geographical information systems (GIS) to } \\
\text { examine maternity care access for expectant mothers in a rural } \\
\text { state. (Gjesfjeld \& Jung, 2011) }\end{array}$ & $\begin{array}{l}\text { Nth Dakota, } \\
\text { USA }\end{array}$ & $\begin{array}{l}\text { Maternity/Rural } \\
\text { Health }\end{array}$ \\
\hline $\begin{array}{l}\text { Distance matters: a population based study examining access to } \\
\text { maternity services for rural women. (Grzybowski, Stoll, \& } \\
\text { Kornelsen, 2011) }\end{array}$ & $\begin{array}{l}\text { British } \\
\text { Columbia, } \\
\text { Canada }\end{array}$ & $\begin{array}{l}\text { Maternity/Rural } \\
\text { Health }\end{array}$ \\
\hline
\end{tabular}

\footnotetext{
${ }^{3}$ One of the first studies to utilize modern geographical techniques in relation to maternity care access
} 


\begin{tabular}{|c|c|c|}
\hline $\begin{array}{l}\text { Choice in maternity care: associations with unit supply, } \\
\text { geographic accessibility and user characteristics (Pilkington, } \\
\text { Blondel, Drewniak, \& Zeitlin, 2012) }\end{array}$ & France & $\begin{array}{l}\text { Maternity/Health } \\
\text { Geography }\end{array}$ \\
\hline \multicolumn{3}{|l|}{ Spatial Access to General Health Care } \\
\hline Health Care Access: A Geographic Overview (Kozyniak, 1982) & New Zealand & Health Geography \\
\hline $\begin{array}{l}\text { Accessibility and Utilisation: Geographical Perspectives on } \\
\text { Health Care Delivery (Joseph \& Phillips, 1984) }\end{array}$ & International & Health Geography \\
\hline $\begin{array}{l}\text { Spatial Patterns of Hospital Utilisation: The Impact of Distance } \\
\text { and Time (McGuirk \& Porell, 1984) }\end{array}$ & $\begin{array}{l}\text { Pennsylvania, } \\
\text { USA }\end{array}$ & Health Geography \\
\hline $\begin{array}{l}\text { Locating a single new facility among existing, unequally } \\
\text { attractive facilities (Drezner, 1994) }\end{array}$ & California & Health Planning \\
\hline $\begin{array}{l}\text { Measuring access to primary medical care: some examples of } \\
\text { the use of geographical information systems (Parker \& } \\
\text { Campbell, 1998) }\end{array}$ & Scotland & $\begin{array}{l}\text { Health Geography/ } \\
\text { GIS }\end{array}$ \\
\hline $\begin{array}{l}\text { Measures of spatial accessibility to health care in a GIS } \\
\text { environment: synthesis and a case study in the Chicago region } \\
\text { (W. Luo \& Wang, 2003) }\end{array}$ & $\begin{array}{l}\text { Chicago, } \\
\text { USA }\end{array}$ & $\begin{array}{l}\text { Health } \\
\text { Geography/Planning }\end{array}$ \\
\hline $\begin{array}{l}\text { Spatial accessibility of primary care: concepts, methods and } \\
\text { challenges. (Guagliardo, 2004) }\end{array}$ & USA & Health Geography \\
\hline $\begin{array}{l}\text { Using GIS to Assess Accessibility to Primary Healthcare } \\
\text { Services (Lovett, Sünnenberg, \& Haynes, 2004) }\end{array}$ & $\begin{array}{l}\text { United } \\
\text { Kingdom }\end{array}$ & $\begin{array}{l}\text { Health Geography/ } \\
\text { GIS }\end{array}$ \\
\hline $\begin{array}{l}\text { Measuring spatial accessibility to primary health care (Bagheri, } \\
\text { Benwell, \& Holt, 2005) }\end{array}$ & New Zealand & Primary Health \\
\hline $\begin{array}{l}\text { The effects of geography and spatial behavior on health care } \\
\text { utilisation among the residents of a rural region.(Arcury et al., } \\
\text { 2005) }\end{array}$ & $\begin{array}{l}\text { Appalachian } \\
\text { USA }\end{array}$ & Rural Health \\
\hline $\begin{array}{l}\text { Neighbourhoods and health: a GIS approach to measuring } \\
\text { community resource accessibility.(Pearce, Witten, \& Bartie, } \\
\text { 2006) }\end{array}$ & New Zealand & $\begin{array}{l}\text { Health Geography/ } \\
\text { Planning/GIS }\end{array}$ \\
\hline $\begin{array}{l}\text { The role of GIS for health utilisation studies: literature review } \\
\text { (Higgs, 2009) }\end{array}$ & International & $\begin{array}{l}\text { Health Geography/ } \\
\text { Planning/GIS }\end{array}$ \\
\hline $\begin{array}{l}\text { Measurement, Optimization, and Impact of Health Care } \\
\text { Accessibility: A Methodological Review. (Wang, 2012) }\end{array}$ & USA & $\begin{array}{l}\text { Health Geography/ } \\
\text { GIS }\end{array}$ \\
\hline $\begin{array}{l}\text { Measuring geographic access to health care: raster and network- } \\
\text { based methods (Delamater, Messina, Shortridge, \& Grady, } \\
\text { 2012) }\end{array}$ & USA & $\begin{array}{l}\text { Health Geography/ } \\
\text { GIS }\end{array}$ \\
\hline $\begin{array}{l}\text { Spatial disparities and travel to freestanding abortion clinics in } \\
\text { Canada (Sethna \& Doull, 2013) }\end{array}$ & Canada & $\begin{array}{l}\text { Women's } \\
\text { Health/Public } \\
\text { Health }\end{array}$ \\
\hline $\begin{array}{l}\text { Investigating Spatial Choice and Navigation in Large-scale } \\
\text { Environments (Gärling, Selart, \& Böök, 2013) }\end{array}$ & International & $\begin{array}{l}\text { Psychology/ Health } \\
\text { Geography }\end{array}$ \\
\hline \multicolumn{3}{|l|}{ Access Modelling } \\
\hline $\begin{array}{l}\text { A Test of Reilly's Law of Retail Gravitation for Northeast } \\
\text { Georgia Hospitals (Longest, 1971) }\end{array}$ & $\begin{array}{l}\text { Georgia, } \\
\text { USA }\end{array}$ & Health Geography \\
\hline $\begin{array}{l}\text { Gravity and Spatial Interaction Models (Haynes \& } \\
\text { Fotheringham, 1984) }\end{array}$ & International & Geography/GIS \\
\hline $\begin{array}{l}\text { A hierarchical location-allocation model with allocations based } \\
\text { on facility size (Hodgson, 1986) }\end{array}$ & Canada & Health Geography \\
\hline $\begin{array}{l}\text { Behavioural Modelling in Geography and Planning (R. Golledge } \\
\text { \& Timmermans, 1988) }\end{array}$ & & $\begin{array}{l}\text { Behavioural } \\
\text { Geography }\end{array}$ \\
\hline $\begin{array}{l}\text { Mathematical location models applied in the spatial organization } \\
\text { of health units (Galvão, Nobre, \& Vasconcellos, 1999) }\end{array}$ & Brazil & $\begin{array}{l}\text { Health Geography/ } \\
\text { Planning/GIS }\end{array}$ \\
\hline $\begin{array}{l}\text { Modeling population access to New Zealand public hospitals } \\
\text { (Brabyn \& Skelly, 2002) }\end{array}$ & New Zealand & $\begin{array}{l}\text { Health Geography/ } \\
\text { GIS }\end{array}$ \\
\hline $\begin{array}{l}\text { Gravity Model Applications in Health Planning: Analysis of an } \\
\text { Urban Hospital Market (Lowe \& Sen, 2006) }\end{array}$ & $\begin{array}{l}\text { Chicago, } \\
\text { USA }\end{array}$ & $\begin{array}{l}\text { Health Geography/ } \\
\text { Planning }\end{array}$ \\
\hline
\end{tabular}




\begin{tabular}{|l|l|l|}
\hline $\begin{array}{l}\text { Automated geospatial model for health services strategic } \\
\text { planning (Hernández-Ávila et al., 2010) }\end{array}$ & Mexico & $\begin{array}{l}\text { Health Geography/ } \\
\text { Planning/GIS }\end{array}$ \\
\hline $\begin{array}{l}\text { Modelling patient choice in healthcare systems: development } \\
\text { and application of a discrete event simulation with agent-based } \\
\text { decision making (Knight, Williams, \& Reynolds, 2011) }\end{array}$ & Illinois, USA & $\begin{array}{l}\text { Health Geography/ } \\
\text { GIS }\end{array}$ \\
\hline $\begin{array}{l}\text { Integrating the Huff Model and Floating Catchment Area } \\
\text { Methods to Analyze Spatial Access to Healthcare Services (J. } \\
\text { Luo, 2014) }\end{array}$ & USA & $\begin{array}{l}\text { Health Geography/ } \\
\text { GIS }\end{array}$ \\
\hline
\end{tabular}

One key piece of New Zealand research identified related to access, and using GIS modelling was carried out by Beere and Brabyn (2006) at a time when many smaller, rural maternity facilities were being closed. The authors proposed several methods could be used to assess maternity facility access in a spatial manner, and selected 'least cost pathway analysis' (LCPA) for their research methodology. This approach measures distance and time between those accessing a service and the physical location of service via the roading network. They found that spatial access varied substantially throughout New Zealand but a significant percentage of the population lived more than sixty minutes from a maternity unit at that time. Although published in 2006, some of the data analysed related to 2001 and in the interim further birthing units have closed. This means the findings (that some areas including Otago were under-serviced), may have been exacerbated since this study was carried out.

There are some methodological issues with Beere \& Brabyn's study though, a crucial one being the selected service population. The authors chose to include the whole population of an area, not just potential childbearing women i.e. the actual service users. Though an explanation for this was given in that a birth event effects the whole family/whanau (p. 139), it would have been more accurate to estimate potential maternity service users. Another critique is that the study did not differentiate between the service levels provided at the closest maternity unit i.e. 
primary, secondary and tertiary level units. This is important as it is likely that the primary service may not provide an appropriate service for all women within its catchment, and so clinical factors will also impact on travel time. The study did acknowledge that geographical factors such as travel time were only part of the narrative around maternity service provision and birthplace choice, and that cultural and economic accessibility were also important.

Looking at the limitations of Beere and Brabyn's study provided a way forward when planning this thesis. It became apparent that it would be critical to obtain data on actual facility utilisation, remain aware of the service levels the facilities in the study region were providing, and also try to assess non-spatial decision factors.

These limitations were confirmed in a larger study, where access to New Zealand public hospitals generally was modelled (Brabyn \& Skelly, 2002). As part of the of the discussion and conclusions, the authors suggest there was potential for further research into "the relationship between hospital accessibility and utilisation" (2002, p. 3) using detailed electronic patient records. Also that it was important to quantify the difference between actual utilisation and perceived accessibility. The first part of this thesis sets out to do that guided by these New Zealand geographical studies.

The literature indicates that if actual facility utilisation was known, predictive geographical models could be used to test whether women made decisions based on geography or where they lived when accessing facilities, or if there were other influences at play. Various geographic modelling systems (Haynes \& Fotheringham, 1984; Knight et al., 2011; Lowe \& Sen, 2006; J. Luo, 2014; Wang, 2012) take into 
account the gravity or attractiveness of the larger obstetric facilities due to their additional complex services. However, the draw of the larger maternity facility still appears to be more than such predictive analysis accounts for, as indicated in the pilot study to this project (Dawson, 2013).

It also needs to be remembered that geographical factors are also bounded by New Zealand's public health system, governmental funding and planning strategies. Much of the research around geographic access, and hence the journey to birth, focusses on rural access and is particularly relevant to a District Health Board with large sparsely populated areas such as Southern (Arcury et al., 2005; Gjesfjeld \& Jung, 2011; Grzybowski et al., 2009, 2011). Although touched on in Hendry's work (Chris Hendry, 2009) about maternity service availability to rural women, there has been little research in New Zealand on both urban and rural women and where they actually travel to birth. Also, no investigation has addressed the definite utilisation of birthing units based on service area populations, as Brabyn and Skelly (2002) recommended.

\section{Psychological distance}

The concept of psychological distance perception was also revealed in the literature. This is spatial reasoning but from an emotive perspective. An example might be one implied in the pilot study (Dawson, 2013); women from the high decile suburb of Whitby that has Deprivation Index of 1 , seldom chose to birth at the closest facility of Kenepuru which is in the very low decile suburb of Porirua (Deprivation Index $=10$ ) (Atkinson, Salmond, \& Crampton, 2014). Longley suggests this kind of decision making is due to geo-demographics (Longley et al., 2011, p. 59) which in the pilot study case, drew women to the higher decile area of 
the Hutt Valley to birth. Longley proposes that people shop, and by extrapolation seek medical services in areas similar to their own. This is reiterated in Gärling (2013), Knight (2011), and Golledge and Stimpson (1996) and falls into the area of behavioural geography.

The first question of this research project was addressed with consideration of the body of literature reviewed, and in particular some of the limitations about health utilisation studies in a literature review on the topic by Higgs (2009). Higgs states that spatial concerns are only one aspect of healthcare utilisation and this is echoed in Gärling, Selart and Böök (2013) and Longely et al (2011) in relation to the psychological aspects of travel choices.

\section{Non-spatial reasons for birthplace choice}

As discussed above, geospatial aspects, travel times, distance and access were only some aspects of choice in birth place, with historical relocation of birth place further despatializing birthplace (Augé, 2008; Prescott, 2009), by removing birth from its traditional geographic links to place, for example the home. Logically, according to the geographical concept of Tobler's Law (Longley et al., 2011) and Central Place Theory (King, 1984), if geography was the only influence, women would access the nearest maternity service or stay home to birth.

Therefore, the literature was explored in relation to the second research question of this thesis: what were the non-spatial factors behind women's choice of birthplace and the decision-making behind their birth journeys? Both the international and New Zealand studies provided assistance with survey design and their methodologies confirm that directly asking birthing women was the only way to accurately establish some of the non-spatial reasons for their birthplace choice. 
The three non-spatial aspects of access - affordability, accommodation, and what is acceptable, as set out by Penchansky and Thomas (1981) - tie in to Anthamatten and Hazen's (2011) introduction of the socioeconomic and class aspects that impact on choice in birthplace in their research on power constructs and the birthplace in the first section of this review. Ethnicity and cultural identification are other factors suggested as significant around birthplace in New Zealand birth research by Davis et al (2011), Longhurst (2008) and Dyck \& Kearns (1995). While sometimes there are pragmatic clinical requirements around birthplace choice, it seems evident that emotional and human aspects are involved when seeking healthcare as well as geographical ones. These findings in the literature informed some of the questions in the survey section of this project.

\section{Birthplace choice in the international literature}

Factors influencing women's choice of birthplace has been researched in many international settings that are not generalizable to the New Zealand context. For example, studies in countries such as Tanzania (Gilhuus, Trandum \& Steen, 2012) where trained birth attendants are seldom available and transport meagre, cannot be compared to a developed nation like New Zealand. This also applies to research from countries acutely affected by conflict, for example Syria (Bashour \& Abdulsalam, 2005) and Palestine (Giacaman, Abu-Rmeileh, \& Wick, 2007). Studies have also been carried out in many places that have vastly different healthcare contexts to New Zealand such as the USA (Boucher, Bennett, McFarlin, \& Freeze, 2009; Cheyney, 2008), Cyprus (Hadjigeorgiou, Kouta, Papastavrou, Papadopoulos, \& Mårtenson, 2012) and France (Combier et al., 2004). While elements from these studies contribute to the body of evidence, the themes can be quite different due to factors not present in the New Zealand context, for example in the USA, the 
healthcare insurance structure must be factored in when comparing to New Zealand's publicly provided maternity system. Like the USA, Cyprus and France don't have an equivalent midwifery-centred maternity care system to New Zealand either. However, one common theme about birth place choice from all these studies, including resource-poor situations, is the birthing women's desire for safety. This proved to be a key concept in other birthplace research and informed a central question in the survey section of this study.

Several major studies examining birthplace choice in environments more generalisable to the New Zealand context were identified, with several large studies in the United Kingdom examining why and how women choose their birthplaces. In considering these studies it should be noted that while the maternity system within New Zealand is not the same as this location, the United Kingdom also has a publically-funded health service and a strong midwifery workforce.

Table 5: International literature that informed survey questions

\begin{tabular}{|l|l|l|l|}
\hline Author \& Title & Setting & $\begin{array}{l}\text { Themes relating to reason for } \\
\text { choice }\end{array}$ & $\begin{array}{l}\text { Related Survey } \\
\text { Question }\end{array}$ \\
\hline $\begin{array}{l}\text { A qualitative study of } \\
\text { information about available } \\
\text { options for childbirth venue } \\
\text { and pregnant women's } \\
\text { preference for a place of } \\
\text { delivery (Madi \& Crow, } \\
\text { 2003) }\end{array}$ & England & $\begin{array}{l}\text { Midwives and partners role in } \\
\text { birthplace choice }\end{array}$ & Influence of others \\
\hline $\begin{array}{l}\text { How women choose where } \\
\text { to give birth (Lavender \& } \\
\text { Chapple, 2005) }\end{array}$ & England & $\begin{array}{l}\text { Multiple factors but main was } \\
\text { safety. Women wanted access to } \\
\text { specialist services (NICU, } \\
\text { obstetricians) }\end{array}$ & $\begin{array}{l}\text { Safety } \\
\text { Services Offered } \\
\text { Travel Time }\end{array}$ \\
\hline $\begin{array}{l}\text { The Birth Place Choices } \\
\text { Project: Phase One (Barber, } \\
\text { Rogers, \& Marsh, 2006) }\end{array}$ & England & $\begin{array}{l}\text { Most women opted for hospital } \\
\text { birth for safety reasons. } \\
\text { Influence of midwives and } \\
\text { partners. Not aware of options }\end{array}$ & $\begin{array}{l}\text { Safety } \\
\text { Influence of others } \\
\text { No other options }\end{array}$ \\
\hline $\begin{array}{l}\text { Factors influencing choice } \\
\text { in birth place -- an } \\
\text { exploration of the views of } \\
\text { women, their partners and } \\
\text { professionals (Houghton, } \\
\text { Bedwell, Forsey, Baker, \& } \\
\text { Lavender, 2008) }\end{array}$ & England & $\begin{array}{l}\text { Safety of hospitals. Acceptance } \\
\text { of interventions }\end{array}$ & $\begin{array}{l}\text { Safety } \\
\text { Services Offered }\end{array}$ \\
\hline
\end{tabular}




\begin{tabular}{|c|c|c|c|}
\hline $\begin{array}{l}\text { First-time expectant fathers } \\
\text { and their influence on } \\
\text { decision making regarding } \\
\text { choice for place of birth } \\
\text { (Mottram, 2008) }\end{array}$ & England & $\begin{array}{l}\text { Partners influence on birth place } \\
\text { decision. Safety concerns. } \\
\text { Information given to partners }\end{array}$ & $\begin{array}{l}\text { Safety } \\
\text { Influence of others }\end{array}$ \\
\hline $\begin{array}{l}\text { "Choice" and place of } \\
\text { delivery: a qualitative study } \\
\text { of women in remote and } \\
\text { rural Scotland (Pitchforth et } \\
\text { al., 2009) }\end{array}$ & Scotland & $\begin{array}{l}\text { Safety most important. Influence } \\
\text { on choice by midwife } \\
\text { information. Wanting to stay } \\
\text { close to home and support } \\
\text { networks. }\end{array}$ & $\begin{array}{l}\text { Safety } \\
\text { Influence of Others } \\
\text { Close to Home } \\
\text { Close to Family } \\
\text { No other options } \\
\text { Travel time } \\
\text { Parity }\end{array}$ \\
\hline $\begin{array}{l}\text { 'She can choose, as long as } \\
\text { I'm happy with it': a } \\
\text { qualitative study of } \\
\text { expectant fathers' views of } \\
\text { birth place (Bedwell, } \\
\text { Houghton, Richens, \& } \\
\text { Lavender, 2011) }\end{array}$ & England & $\begin{array}{l}\text { Multiple factors in decision } \\
\text { making. Safety. Partner influence }\end{array}$ & $\begin{array}{l}\text { Safety } \\
\text { Influence of others }\end{array}$ \\
\hline $\begin{array}{l}\text { Women's perceptions of } \\
\text { their right to choose the } \\
\text { place of childbirth: an } \\
\text { integrative review } \\
\text { (Hadjigeorgiou, Kouta, } \\
\text { Papastavrou, Papadopoulos, } \\
\text { \& Mårtensson, 2012) }\end{array}$ & International & $\begin{array}{l}\text { Review: Influence of the medical } \\
\text { model. Safety. Influence of } \\
\text { information provided by } \\
\text { maternity carers }\end{array}$ & $\begin{array}{l}\text { Safety } \\
\text { Influence of Others } \\
\text { Services Offered } \\
\text { No other options }\end{array}$ \\
\hline $\begin{array}{l}\text { Birth Place Decisions : a } \\
\text { prospective, qualitative } \\
\text { study of how women and } \\
\text { their partners make sense of } \\
\text { risk and safety when } \\
\text { choosing where to give } \\
\text { birth (Coxon, 2012) }\end{array}$ & England & $\begin{array}{l}\text { Risk aversion. Obstetric Unit the } \\
\text { 'normal' place for birth }\end{array}$ & $\begin{array}{l}\text { Safety } \\
\text { Services Offered } \\
\text { Influence of Others } \\
\text { Demographics }\end{array}$ \\
\hline $\begin{array}{l}\text { To what extent are women } \\
\text { free to choose where to give } \\
\text { birth? How discourses of } \\
\text { risk, blame and } \\
\text { responsibility influence } \\
\text { birth place decisions } \\
\text { (Coxon et al., 2014) }\end{array}$ & England & $\begin{array}{l}\text { Birth is risky. Obstetric Unit the } \\
\text { 'normal' place for birth }\end{array}$ & $\begin{array}{l}\text { Safety } \\
\text { Services Offered } \\
\text { Demographics }\end{array}$ \\
\hline
\end{tabular}

Several initiatives within the United Kingdom health services generated much of this research (Department of Health, 1993, 2007; National Perinatal Epidemiology Unit (NPEU), 2014). Although these studies focussed on availability and information about choice of birthplace and outcomes related to differing birth facilities, secondary findings examined the influences on and reason for women's actual choice. 
The themes identified in this study (as set out in Table 5) informed the core questions in the survey component of this thesis. For example, Lavender and Chapple (2005) surveyed women in the antenatal period about their chosen birthplace. The sample included women from a variety of socio-economic and ethnic backgrounds and involved both rural and urban women. Multiple factors were found for choices but safety was a significant priority. Also, women stated they wanted their antenatal care available locally but $68 \%$ were prepared to travel for their birth. These findings aided the development of the survey analysis plan, and also the question regarding actual time to travel to birthplace.

In a different setting again, that of remote rural Scottish women (Pitchforth et al., 2009), similar issues emerged. Previous experiences and the need for safety were balanced by perception of quality of care that a maternity unit might provide. Two specific themes of geographical accessibility and a desire for family and social support appeared in this study, something not specifically raised or apparent in the findings of the urban-centred research. Survey questions around desire to be near home and family were included as a result of these findings.

The theme of the role of the woman's partner and maternity care providers was also acknowledged in several other studies (Bedwell et al., 2011; Houghton et al., 2008; Mottram, 2008) and informed the survey question about the influence of maternity carers in birthplace choice. There was also the common thread about seeking out the safest place to birth, most frequently seen as a hospital. Bedwell et al in particular recognised an "overwhelming trust in the medical environment" dominating the partner's beliefs and perceptions of risk (2011, p. 71). 
The discourses on risk and blame around birth, and how these affect birthplace choices also featured in an article and a thesis stemming from the Birthplace study (Coxon et al., 2014; Coxon, 2012). The authors contend that complex social and cultural factors influence high numbers of women choosing to birth in obstetric hospital settings, and that primary units were not seen as a cultural norm in their research setting.

\section{Birthplace choice in New Zealand}

Several New Zealand studies have addressed the issues of reasons for birthplace choice either directly or as part of wider research, as tabled below.

Table 6: New Zealand literature about Non-Spatial reasons for birthplace choice

\begin{tabular}{|c|c|c|c|}
\hline Author \& Title & $\begin{array}{l}\text { Directly } \\
\text { addresses } \\
\text { choice }\end{array}$ & $\begin{array}{l}\text { Themes relating to reason } \\
\text { for choice }\end{array}$ & $\begin{array}{l}\text { Related Survey } \\
\text { Question }\end{array}$ \\
\hline $\begin{array}{l}\text { Being safe in childbirth : a } \\
\text { hermeneutic interpretation of the } \\
\text { narratives of women and } \\
\text { practitioners (Smythe, 1998) }\end{array}$ & No & $\begin{array}{l}\text { Thesis: Women's attitudes to } \\
\text { safety in birth }\end{array}$ & $\begin{array}{l}\text { Safety } \\
\text { Close to home \& } \\
\text { family } \\
\text { Influence of } \\
\text { others }\end{array}$ \\
\hline $\begin{array}{l}\text { Risk and the Midwife: a } \\
\text { Descriptive and Interpretive } \\
\text { Examination of the Referral for } \\
\text { Obstetric Consultation Practices } \\
\text { and Attitudes of New Zealand } \\
\text { Midwives (Skinner, 2005) }\end{array}$ & No & $\begin{array}{l}\text { Thesis: Risk concepts around } \\
\text { childbirth. Midwives } \\
\text { working with risk }\end{array}$ & $\begin{array}{l}\text { Safety } \\
\text { Influence of } \\
\text { others }\end{array}$ \\
\hline $\begin{array}{l}\text { A Time of Travelling Hopefully: a } \\
\text { Mixed Methods Study of Decision } \\
\text { Making by Women and Midwives } \\
\text { about Maternity Transfers in Rural } \\
\text { Aotearoa, New Zealand (Patterson, } \\
2009 \text { ) }\end{array}$ & Yes & $\begin{array}{l}\text { Thesis: Midwives working in } \\
\text { rural areas. Women's fear of } \\
\text { emergency transfer } \\
\text { Women wanting to remain } \\
\text { close to home and support } \\
\text { balanced against } \\
\text { attractiveness of primary } \\
\text { units }\end{array}$ & $\begin{array}{l}\text { Safety } \\
\text { Travel Time } \\
\text { Close to home \& } \\
\text { family } \\
\text { Influence of } \\
\text { others } \\
\text { Services Offered }\end{array}$ \\
\hline $\begin{array}{l}\text { Choosing the place of birth : how } \\
\text { primigravida women experiencing } \\
\text { a low-risk pregnancy choose the } \\
\text { place in which they plan to give } \\
\text { birth in New Zealand (Howie, } \\
\text { 2007) }\end{array}$ & Yes & $\begin{array}{l}\text { Thesis: The right place, } \\
\text { external influences, pain } \\
\text { relief. } \\
\text { Birthplace choice reflects } \\
\text { philosophy about birth }\end{array}$ & $\begin{array}{l}\text { Safety } \\
\text { Close to home \& } \\
\text { family } \\
\text { Influence of } \\
\text { others } \\
\text { Services Offered }\end{array}$ \\
\hline $\begin{array}{l}\text { Do low risk women actually birth } \\
\text { in their planned place of birth and } \\
\text { does ethnicity influence women's } \\
\text { choices of birthplace? (Davis et al., } \\
\text { 2011) }\end{array}$ & No & $\begin{array}{l}\text { Ethnic influence on } \\
\text { birthplace choice }\end{array}$ & $\begin{array}{l}\text { Demographic } \\
\text { questions }\end{array}$ \\
\hline
\end{tabular}




\begin{tabular}{|l|l|l|l|}
\hline $\begin{array}{l}\text { Are First-Time Mothers Who Plan } \\
\text { Home Birth More Likely to } \\
\text { Receive Evidence-Based Care? A } \\
\text { Comparative Study of Home and } \\
\text { Hospital Care Provided by the } \\
\text { Same Midwives (Miller \& Skinner, } \\
\text { 2012) }\end{array}$ & & $\begin{array}{l}\text { Midwives influence on } \\
\text { birthplace choice }\end{array}$ & $\begin{array}{l}\text { Influence of } \\
\text { others } \\
\text { Safety }\end{array}$ \\
\hline $\begin{array}{l}\text { An exploration of influences on } \\
\text { women's birthplace decision- } \\
\text { making in New Zealand: a mixed } \\
\text { methods prospective cohort within } \\
\text { the Evaluating Maternity Units } \\
\text { study (C. Grigg et al., 2014) }\end{array}$ & Yes & $\begin{array}{l}\text { Ideology around birth } \\
\text { influences birthplace choice. } \\
\text { Clinical safety a primary } \\
\text { decision influence }\end{array}$ & $\begin{array}{l}\text { Safety } \\
\text { Influence of } \\
\text { Others } \\
\text { Demographic } \\
\text { questions }\end{array}$ \\
\hline
\end{tabular}

Of note within the literature reviewed was Patterson's study (2009) that gained an insight into women's influences when choosing to birth at rural maternity units or not, in her exploration of rural maternity transfer patterns. The qualitative section of this mixed methodology study provided some understanding of rural women's birth place choices in the recent New Zealand maternity landscape. The theme of choosing the safest place to birth emerged in this discourse, with rural women's awareness of the distance and time to secondary services in the event of problems and a fear of transfer. This was balanced with attractiveness of birth close to home, friends and family and often the impression of more individual care at rural maternity units (Patterson, 2009). This work was particularly applicable to the large rural areas in the Southern District Health Board.

Finally, a very recent New Zealand study (Grigg et al., 2014) explored birthplace choices in an urban context, where women had the choice of a tertiary maternity unit and several primary units in city area. Recruiting in the southern city of Christchurch, and using mixed methods including a survey and focus groups, the authors detected themes around safety as being common to women who choose to birth at both kinds of maternity facility. The social contexts such as the importance of closeness to home and access differed between the primary/tertiary groups, with 
safety being more important to the tertiary unit birth group. While this study was not available during the design of this research project, the results again provided a useful comparator to the findings of this thesis around the influences on urban women's birthplace choices, when choices are available. It is of note that the Christchurch women in Grigg et al's study had a choice of facility in the urban situation, whereas the two main urban centres of Invercargill and Dunedin in the Southern District Health Board area do not have separate stand-alone primary maternity facilities, thus limiting choice.

The overwhelming theme throughout these studies on birthplace choice was one of safety. Access to family support and the influences of partners and caregivers were secondary to the need for what was perceived as the safest place to give birth. Themes of safety were prominent in Skinner's work on risk (2005) and Symthe's hermeneutic study on childbirth safety (1998). All these study findings helped structure the survey for this thesis but also provided a comparison framework for results obtained in this thesis.

Many studies were found examining access to maternity care and general health services, and the geospatial factors around that. A separate body of work was identified in regard to personal reasons for birthplace choice unrelated to geography. No study was identified that looked at both spatial and non-spatial birthplace choices and their interactions. This research sets out to review that in the context of the Southern District Health Board region. 


\section{Chapter 3 - Research Design and Methodology}

This study is a mixed method piece of descriptive research in two parts. Firstly, a geographical data analysis of maternity travel patterns in 2013 using ArcGIS 10.2.2 mapping software (ESRI, 2013) was undertaken. This was followed by a district-wide survey of birthing women in the Southern District Health Board to assess their attitudes and choices around geographical place of birth.

\section{Geographic Analysis}

The use of geographic perspectives to study health and health care has been an evolving field since Hippocrates wrote of 'airs, waters, places' being important factors impacting on human health (Bashford \& Tracy, 2012). The topic is broadly divided into two streams: disease distribution; and provision of healthcare services (Gregory et al., 2009). Over time, these strands have merged and been influenced by both quantitative (e.g. modelling, spatial analysis and geographic information systems) and qualitative (e.g. post-structuralist and feminist) approaches, combining to form what Kearns terms, a "reformed medical geography", focusing on "consequences of illness and health service provision for both personal well-being and the collective experience of place by communities" (Kearns, 1993, p. 139).

By evaluating healthcare through a geographic framework, researchers can assess spatial patterns such as disease distributions, but also how space and time impact on healthcare decisions (Hazen \& Anthamatten, 2011). In this project, three phases of spatial analysis and modelling have been carried out, to compare actual birth place choice with expected predictive spatial choices. The initial phase simply describes utilisation, while the second compares geographical decision making models to these utilisation patterns to ascertain correlation between spatial choice 
and actual choice. Lastly, the current locations of maternity services were assessed and new locations and services hypothesised to see what impact these changes may have on birthplaces choices.

\section{Point Data for all 2013 births in the Southern District Health Board}

Geographical point data was obtained for place of birth and place of residence for all women birthing within the Southern District Health Board geographical boundaries (New Zealand Ministry of Health, 2012) in 2013.

A dataset of geographic latitude and longitude co-ordinate pairs was established from electronic records of addresses extracted from the Southern District Health Board inpatient management system (iPM). The point data (latitude and longitude co-ordinates) was generated by geocoding the residential address information of the women giving birth and related to birth location (Longley et al., 2011, p. 142).

The four privately-run maternity facilities that are contracted to the Southern District Health Board manually provided address lists of their 2013 birthing population. These were also geocoded to co-ordinate pairs.

\section{Geocoding}

A final list of 3283 addresses of women who birthed at the ten Southern District Health Board maternity facilities was obtained. Firstly, the addresses needed to be converted to a standardised format and rural delivery (RD) numbers removed to provide a physical, non-postal address, so that a computer software script could translate the address into co-ordinates. Sometimes this required investigative work as addresses were occasionally just a road name and no number or a station/farm/business name. Physical addresses were found for all but a handful - 
mainly by using Google. By going back to the District Health Board Information Technology department for further details, the remaining few were resolved.

Once a clean address data set was established, each address was copied into a JavaScript software utility that took the address, passed it to Google Maps via an Application Programming Interface (API), and returned latitude and longitude coordinates. The JavaScript was based on code freely available online (Williams, 2008). Addresses were processed in batches of two hundred. The data cleaning, address formatting and geocoding was an extremely time-intensive process.

These geocoded co-ordinates provided point data for the birthing women's residential address (or what could be called demand points) related to the place in which they gave birth (a supply point). Demand points are where a person travels from to seek out a service or item and a supply point is where the service is being supplied or sold from and therefore where the person is travelling to.

\section{Services Areas and Road Networks}

The geocoded point data pairs of home address and birth place were used to map travel patterns and maternity facility utilisation within the District Health Board, as well as establish catchment areas for each unit by mapping drive time service areas. The service area was defined as a perimeter around each facility that represented a specific actual driving time to that facility i.e. anyone inside that perimeter would take X minutes or less to drive to the unit (T. Brown, McLafferty, \& Moon, 2010; Kurland \& Gorr, 2014).

Initially, an outer boundary of sixty minutes was used, sometimes known as 'the golden hour'. This is a term commonly used in medicine to imply the urgency in receiving treatment within one hour in emergency situations, although it is based on 
negligible evidence (Lerner \& Moscati, 2001). The Golden Hour is also utilized in service planning and access to health facilities for similar, but somewhat arbitrary reasons (Brabyn \& Skelly, 2002). However, due to the geographical distribution of maternity facilities in the Southern District Health Board, and it being a common service area definition in other healthcare access studies (Cromley \& McLafferty, 2002; Delamater, Messina, Shortridge, \& Grady, 2012; Kara \& Istvan Oliver, 2013; W. Luo \& Wang, 2003; Rooväli \& Kiivet, 2006), it was decided to use a smaller thirty minutes' drive time. This service area is also reflected in the Ministry of Health Service specifications (Ministry of Health \& DHBNZ, 2011).

The service areas were defined by using each maternity facility as a central point on a connected road transport network; the ArcGIS online logistics service calculated a thirty minute drive time distance on each road leading out from that central point. Various parameters were able to be set, such as the hierarchy of roads to be used. This is used to simulate the preference of a driver who may choose to travel on highways rather than local roads when possible - even if that means a longer trip. Due to the rural nature of much of the Southern District Health Board, the simulation was enabled to use unpaved roads, and also private roads if necessary.

Online Routing \& Network Analysis and Logistics Services for ArcGIS via ESRI were utilized to create very precise and accurate service area catchments for each maternity facility in the Southern District Health Board, as above. ESRI's historical, and predictive traffic feeds come directly from HERE (formerly NAVTEQ), an international company that supplies mapping, traffic and routing data to businesses such as BMW, Toyota and Garmin navigation. HERE collects billions of GPS and cell phone probe records per month, and compiles the data to compute accurate travel speeds worldwide (ESRI, 2014; HERE, 2014). 
The software and online services used had the capacity to model drive time for time of day (but not season), but this was not used. All drive time calculations (and all modelling in this study) were estimated using private car as the mode of transport. It was possible to model walking, several different modes of public transport, and trucks of various types but it was assumed that most women would reach their birth destination by car, or in an emergency, an ambulance. Again, this assumption is reflected in other access studies including a New Zealand one by Brabyn \& Skelly (2002).

Using ArcGIS, the residential data points of women could be analysed to assess spatial and statistical relationships between locations, assess travel impedances, and compare how desirable each maternity facility destination was in terms of women who chose to go there. Firstly, birthing women within a catchment or service area were evaluated to see if they utilized their closest facility or not and if not, where they did choose to birth.

Geographical and statistical analysis tools within the software were then used to see which women did not fall inside any service area, over-lapping service areas, and areas of isolation, leading to some predictive modelling as further described.

\section{Gravity Modelling}

This detailed dataset allowed some tools to be employed to see if there might be spatial explanations for some of these journeys. There are many ways of investigating the interactions of people and their geographical environment as discussed in the landmark texts by Golledge and Timmermans $(1996 ; 1988)$ but they are commonly based on gravity modelling. 
Gravity modelling stems from Tobler's First Law of Geography, which states that "Everything is related to everything else, but near things are more related than distant things" (Longley et al., 2011, p. 77). Gravity modelling is used to represent spatial interaction and movement patterns in human geography. With its roots in retail site establishment, it is analogous with Newtonian physics and the relationship between size of objects or places and the distances between them (Gregory et al., 2009). A key concept of gravity modelling is that of distance decay, whereby the gravity or attractiveness of a place decreases the further away from it a person is located. Although critiqued for being somewhat reductionist in simulating equations from physics, improvements on basic models and refinement of parameters can be applied, especially in cases of service provision (T. Brown et al., 2010; Gregory et al., 2009).

Figure 4: Illustration of Gravity Modelling (Adapted from Haynes \& Fotheringham (1984))

\section{Illustration of the Gravity Model}

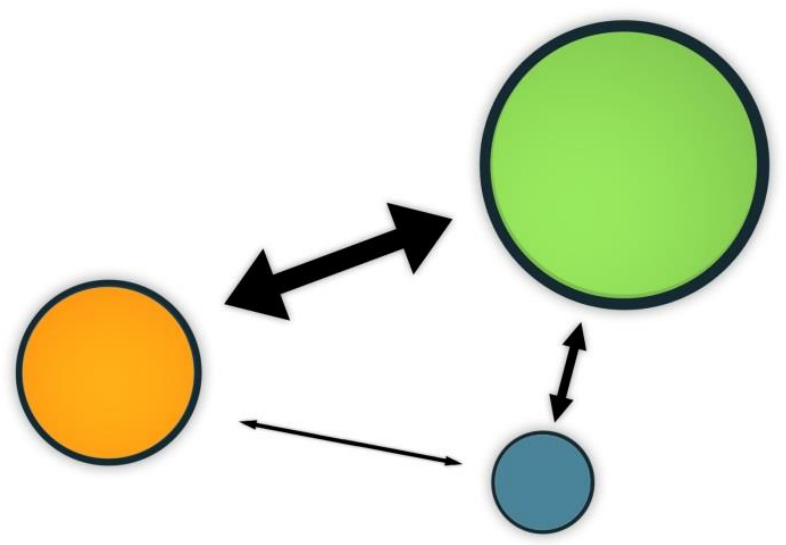

The shorter the distance between two objects, and the greater the mass of either (or both) objects, the greater the gravitational pull between the objects. 
Gravity modelling was carried out using two basic methods: Reilly's Law which only examines the gravity between two specific points; and Huff Modelling, which can analyse multiple points where there are several facility options available. Reilly's Law is very basic but can explain the point between two facilities where one ceases to be as attractive as the other using mathematical formulae (see Figure 5). This is one of a number of gravity models utilized in in healthcare analysis and planning (Combier et al., 2004; Congdon, 2000; Longest, 1971).

Figure 5: Reilly's Law Example (Adapted from Rodrigue (2014))

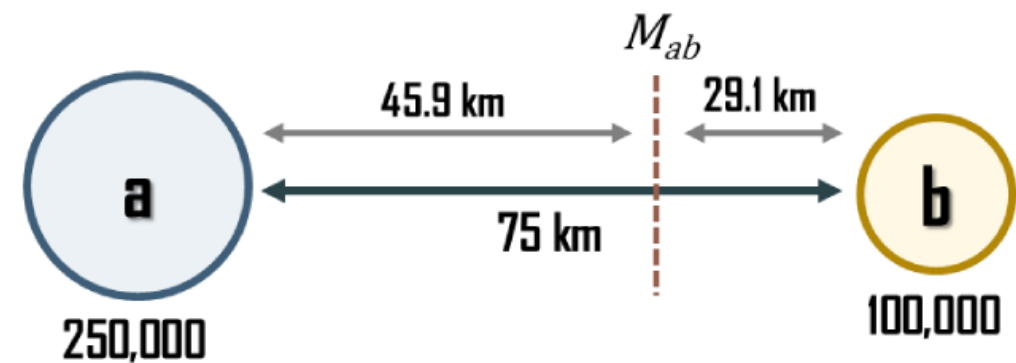

$$
\begin{gathered}
M_{a b}=\frac{D_{a b}}{1+\sqrt{P_{b} / P_{a}}} \quad M_{a b}=\frac{75}{1+\sqrt{100,000 / 250,000}} \\
M_{a b}=45.9
\end{gathered}
$$

Huff Modelling, also originally a retail model, has been used widely to model potential utilisation in areas where multiple facilities are available. It can also be used to predict the best locations for health service provision for maximum utility (T. Brown et al., 2010; R. D. Golledge \& Stimpson, 1996; Lowe \& Sen, 2006; J. Luo, 2014). 


$$
\begin{aligned}
& P_{i j}=\frac{A_{j}^{\alpha} D_{i j}^{-\beta}}{\sum_{j=1}^{n} A_{j}^{\alpha} D_{j j}^{-\beta}} \\
& \text { Where: } \\
& \text { - } \text { A } j \text { is a measure of attractiveness of store } \mathrm{j} \text {, such as square footage } \\
& \cdot \text { Dij is the distance from } i \text { to } j \\
& \cdot \alpha \text { is an attractiveness parameter estimated from empirical observations } \\
& \cdot \beta \text { is the distance decay parameter estimated from empirical observations } \\
& \cdot n \text { is the total number of stores including store } j .
\end{aligned}
$$

The Huff model simulates the choices a person may make when faced with several facilities they might attend, rather than just two points. Huff modelling also allows for complex parameters and weightings rather than the simplistic population gravity of Reilly's Law. These parameters can even be configured for individual preferences once factors influencing choice are known (D. L. Huff, 2003; D. Huff \& McCallum, 2008). An example would be refining the results of the survey section of this study about what factors are important to women in their choice of maternity facility and include those factors as weighting parameters in an advanced Huff model (e.g. $\alpha$ in Figure 6). An additional script module for the ArcGIS software (Flater, 2010) was utilized to run the Huff model, testing for best fit of maternity facility against demand and probability of accessing any particular unit by any woman who birthed in 2013.

Derived from the actual 2013 travel patterns, all primary units were given a weighting of 1, the secondary unit in Invercargill a 3, and the tertiary unit in also Dunedin a 3. Invercargill and Dunedin were given equivalent weightings, as apart from proximity, the services at both sites are very similar. This was based on best case demand figures from actual 2013 data. The need to access tertiary services over 
secondary, would be dictated by clinical necessity (for example access to a neonatal intensive care unit able to accept babies with gestation less than 32 weeks) and therefore unlikely to be a choice.

Once the models were run with the 2013 birthing data, actual travel was compared to the predicted journeys from the Reilly and Huff models. The comparison indicated if gravity and distance decay appeared to be significant factors in birth place choice.

It should be noted that both Reilly's and Huff's models are mainly determinist in approach, reducing women's choice to mathematical formulae (even with fine-tuning of Huff parameters). Knight (2011) introduces how the reality of 'patient' choice in healthcare is much more complex and this is reflected in more recent dynamic models (Wang, 2012). However, as is explored in this thesis birthplace choice may be even more complex than decision-making around accessing other healthcare services.

\section{Exploratory modelling - Location-Allocation}

The final section of spatial analysis was exploratory and utilized a locationallocation model to speculate on potential new or improved locations for maternity facilities in areas that appeared to have limited maternity coverage in the preceding analysis. This was to test if travel patterns to birth location were perhaps influenced by poor service location.

Location-Allocation is a spatial method often used to establish optimal positioning for healthcare services (T. Brown et al., 2010; Cromley \& McLafferty, 2002; Hodgson, 1988; Pratt, Moore, \& Craig, 2014; Wang, 2012) and examines two 
decisions "where to locate and how to allocate demand for service"(Longley et al., 2011, p. 395). This system was used to examine regions in the Southern District Health Board where women appeared to be making the longest journeys from, and to check whether provision of additional or better located maternity facilities would improve service access.

Due to population growth and limited maternity service coverage, the Central Otago region was selected for this analysis. Using two existing sites, Lakes Hospital in Queenstown and Charlotte Jean in Alexandra, one potential site in central Cromwell and another in Wanaka, the Location/Allocation online service was utilized in the ArcGIS software to find the best-fit maternity facility for this area.

Again, based on the journeys made in the initial travel analysis of 2013 data, weightings were generated for each class of facility based on actual utilisation and services provided. All primary facilities were allocated "1" as a basic weighting. The complex care facilities in Invercargill and Dunedin were allocated a “3”, as women were approximately three times more likely to access those types of maternity facility at best. In some areas, e.g. Queenstown, the weighting could have been calculated differently as there was a stronger draw towards the complex care units. The hypothetical secondary service in Cromwell was also allocated a "3" weighting, based on 2013 patterns.

\section{Issues and responsibilities when mapping health information}

The Health Privacy Act states that the data obtained for research must " not be published in a form that could reasonably be expected to identify the individual concerned" (Office of the Privacy Commissioner, 2008, p. 59), and this is of key 
concern when mapping health information in any context (Brownstein, Cassa, \& Mandl, 2006; Cassa, Wieland, \& Mandl, 2008)

One challenge of the project was the need to protect the confidentiality of individuals when the demand point data referred to an individual woman's residence, whilst maintaining the integrity of the spatial data; this was especially relevant in respect to service area topologies and birth journeys. Therefore, a process was developed to obfuscate the data set to allow the results to be visually presented as maps and diagrams in this thesis and elsewhere whilst protecting anonymity (Dawson, 2013; Duckham \& Kulik, 2005, 2006).

In some instances schematic maps, where identifying topological information is removed, have been used to illustrate travel and birth journeys so residential locations cannot be identified. In others, precise measures of distance, where potentially identifying, have been rounded to the nearest two kilometres.

\section{Survey}

In the second section of this thesis, a cross-sectional paper-based survey was carried out over a three month period (April-June 2014) for all women giving birth to live babies in the Southern District Health Board. The results were compared against District Health Board demographic information and existing research.

\section{Sample Size}

The estimated sample size was based on 2013 birth numbers for each facility, provided by the Southern District Health Board iPM database system directly and from private health trusts. The total number of live births in Southern District Health Board facilities in 2013 was 3283. Therefore, the total possible number of respondents in a three month period was estimated at approximately 821 . 


\section{Physical Design}

There were potentially a large number of returned questionnaires to be entered into a dataset, even with a modest response rate. Therefore, it was decided to use the Cardiff Teleform software system to format and produce the questionnaire, so they could be automatically scanned and stored on completion. This required a little training and guidance but the form was designed and modified during pretesting; data entry (scanning and correcting forms as necessary) was also completed at the end of the survey period using this system. The format of the core questions (visual analogue scales) in the survey was made in consultation with a biostatistician and confirmed during pre-testing.

\section{Survey Questions}

The questionnaire (Appendix 2) began with residential address. Questions 2 and 3 asked for planned place of birth and whether there was any clinical reason that had restricted birth place choice for the woman. Address details enabled a urban/rural/remote rural classification according to maternity service specifications derived from section 88 domicile code classifications (Ministry of Health, 2002).

Question 4 "Please rate your reasons for choosing your place of birth from most important to least important. Rank as many or few as you want" was the core of the survey. Also it was the most difficult to get answered in a meaningful way during pretesting and design, and also when the questionnaire was completed in the field.

Some of the birth choice reasons set out in this question were derived from previous research, as outlined in the literature review section of this thesis (Abel \& Kearns, 1991; Bedwell et al., 2011; Hadjigeorgiou, Kouta, Papastavrou, Papadopoulos, \& Mårtensson, 2012; Houghton et al., 2008; Mottram, 2008; 
Pitchforth et al., 2009). However, some selections were included due to the context of the Southern District Health Board e.g. "No other options in my area". An example where this may have been relevant are the Dunedin and Invercargill areas served by large complex care hospitals and no separate primary birth unit. Another option "The place my midwife /doctor recommended" was included to see if carer influence was a factor in birthplace choice. Finally there was an "other" option with a space for free text.

The questionnaire then moved on to confirming actual place of birth and options to indicate why it was different from planned place, if applicable. This was included to give an indication of transfer data.

Question 8 asked about the time it took to travel to their place of birth. The rest of the questionnaire was demographic in nature.

Demographic questions in this survey questionnaire are taken from a set of standard core demographic questions developed by Statistics New Zealand (Statistics New Zealand, 2014a). Data relating to income, educational level, ethnicity, age and parity was collected to ascertain if there were differences in birth place choices related to demographic factors; ethnicity and decile have been suggested as significant influences by other studies (Abel \& Kearns, 1991; Davis et al., 2011; Ellis, 1998; Overgaard, Fenger-Grøn, \& Sandall, 2012).

\section{Pre-testing}

Draft questionnaires were pre-tested three times on selected groups within a tertiary hospital postnatal ward environment. Using Bowden's qualitative framework for pre-testing (2002), extensive written and verbal feedback on the questionnaire content, layout and questions was sought from different groups of testers including 
the target group. The groups and questionnaires were refined in the pretesting phases. The main recommendation from Hunt, Sparkman and Wilcox (1982) was employed; testing was done in person even for this self-administered questionnaire. The first questionnaire test was carried out on a mixed group of birthing women, midwives, student midwives, medical students, senior medical consultants and health academics $(n=15)$. It was very interesting to note that there was no intergroup variance as to how the survey was answered. Issues raised and difficulties in answering some sections, particularly Question 4, were common to all groups.

The questionnaire was modified and Question 4 changed from a ranking question to a rating one. This was a difficult compromise as the aim was to have each reason for birthplace choice and birth journey ranked and ordered from 1 to 7 , clearly indicating what was most important. Even with clear instructions, some from every group simply ticked option boxes rather than inserting a numerical rank.

\section{Ranking versus Rating}

At this point, a search of literature around ranking questions provided some possible reasons for poor completion of the ranking question. Alwin \& Krosnick (1985) suggest that the more choices there are to rank, the more complex and mentally taxing the task becomes. Changing to a rate system usually improves accurate data capture. 
Figure 7: Rating Versus Ranking - Adapted from Alwin \& Krosnick (1985)

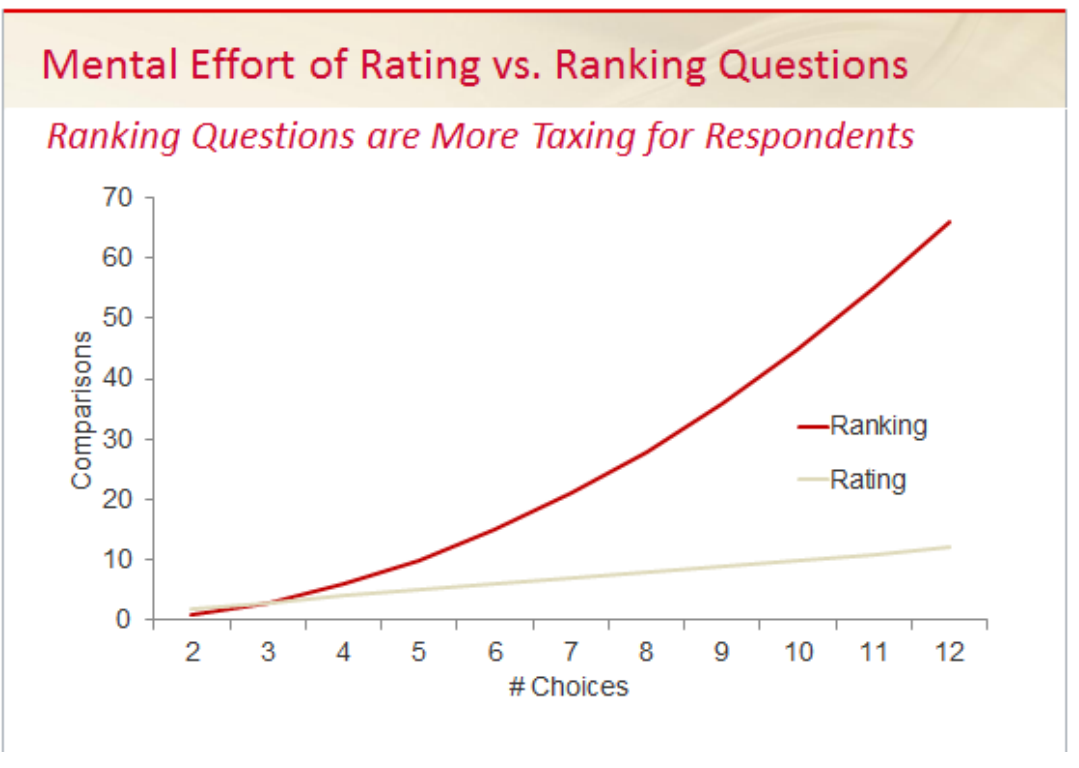

For the second round of pre-testing $(n=10)$, the response to Question 4 when reformatted as a rating system (see Figure 8) improved markedly, but still many people selected more than one factor as "most important" or rated more than one item at the same level. Again, there was no intergroup variance of note.

Figure 8: Version 2 Survey Format Question 4(a)

\begin{tabular}{|c|c|c|c|c|c|c|c|}
\hline & Least & & & & & & $\begin{array}{l}\text { Most } \\
\text { important }\end{array}$ \\
\hline a. Close to home. & O & O & O & O & $\mathrm{O}$ & $\mathrm{O}^{\prime}$ & O \\
\hline b. Close to family. & 0 & 0 & 0 & 0 & 0 & 0 & 0 \\
\hline c. No other options in my area. & O & O & O & O & O & $\mathrm{O}$ & O \\
\hline $\begin{array}{l}\text { d. Services offered e.g } \\
\text { (pain relief, surroundings). }\end{array}$ & ○ & O & ○ & ○ & O & O & ○ \\
\hline e. The place my midwife /doctor suggested. & ○ & O & ○ & O & O & O & ○ \\
\hline f. Where I felt safe. & O & O & O & O & O & O & ○ \\
\hline g. Other, Please explain below & O & O & O & O & O & O & 0 \\
\hline
\end{tabular}

The most successful formatting was found in pre-test 3, with a visual analogue scale system where a series of bars could be marked/rated in a very finely differentiated manner $(1 \%-100 \%)$ to indicate what factors were most important in choice of birth place. This final pre-test $(n=8)$ was carried out in the proposed live survey setting of the Dunedin Hospital postnatal ward and only included women 
who had recently given birth. As with the other pre-tests, women were advised that this was pure testing and they could make up answers, but to answer as they would with real data. The women in this final testing stage were incredibly generous with their feedback and comments. While Q4 was left 'as is', some other formatting and wording changes were made.

Figure 9: Final Survey Format Question 4(a) - Visual Analogue Scale

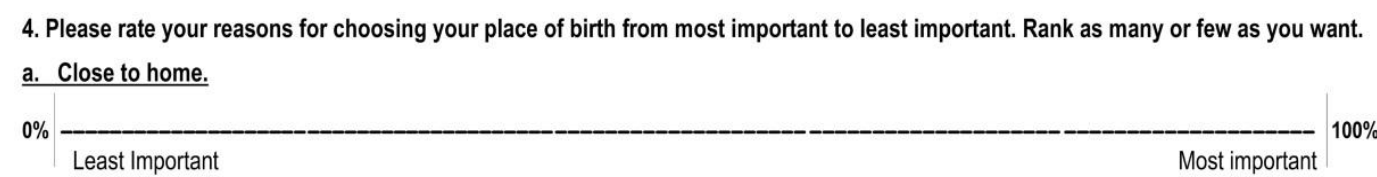

\section{Response Rates}

Response rates vary considerable in cross-section surveys and according to Massey and Tourangeau (2012), non-response rates have been trending upwards over time, with a non-response rate of $60 \%$ now not uncommon in postal surveys. These authors suggest this may be due to a certain amount of survey fatigue and therefore being involved in survey research lacks significance. One recommendation is that all effort being put into strategies that improve response rates, which means less time spent in analysis adjusting for possible low return rates. These themes are also echoed in work by Brown, Long, Gould, Weitz, \& Milliken which address specific issues around recruiting a diversity of women into research (2004).

Research in this area, and also Hohmann \& Parron's guidelines on the inclusion of women in research (1996), was congruent with local research assistant experience recruiting women in the postnatal period. Familiarity with this environment and with birthing women as registered midwife also informed several strategies in an attempt to improve survey response rates. 
The paper questionnaire was designed to be offered to women immediately post-partum in all of the Southern District Health Board maternity facilities and completed and returned while the women were inpatients. This gave a distinct and finite time frame for completion, and also it was anticipated that women may have time to fill out the survey before they went home to new motherhood and other responsibilities. Experience in research recruitment in this context also excluded utilizing a solely online survey due to historically poor response rates as women become preoccupied on returning home after discharge.

\section{Strategies employed to improve response}

- The survey questionnaire was extensively pre-tested to maximise clean data return, identify problematic questions, improve formatting, and to keep it as simple as possible. Some compromises had to be made during this process.

- The questionnaire was kept as short and as simple as possible whilst asking critical questions.

- Clear plain language instructions were included.

- "buy in" was sought from all maternity units were the survey was to be distributed and collected. A presentation was given prior to the start of the study to facility leaders; all were very keen to support the study as they saw value in the results for their units, particularly the small rural facilities.

\section{Distribution and Collection}

Support was gained from management at all maternity facilities for them to be sent questionnaires and develop ways of offering these to all women in their units 
during the survey period that suited their staff and situation. Bright, "branded" collection boxes were provided to assist staff and women in collecting the completed forms. Frequent phone contact was made with each centre throughout the survey period and personal visits made. At the end of the period, courier packs were provided to the units for return of the forms.

\section{Analysis}

Demographic comparison was made between the survey sample obtained, the 2011 and 2013 Maternity Tables, and 2013 census information for the Southern District Health Board region. STATA (StataCorp, 2014) software was used for statistical analysis of questionnaires for possible relationships between responses to the core questions and other factors including demographics (e.g. parity, ethnicity, length of birth journey) using Pearson's Chi-Square test (or Kurskal-Wallis if distribution was not normal). Analysis was also done for selected birthplace location (complex, primary, home) and demographic variables.

As the visual analogue scale format of the core questions can lend itself to abnormal distribution, the responses to these questions were also tested for skew and kurtosis.

\section{Reliability and Validity}

The phases of this research generated several datasets, questionnaire data, Statistics New Zealand pilot study data, and data extracted from the District Health Board records. Existing datasets were used for comparison e.g. Ministry of Health maternity reports from the national dataset. These steps ensured that there were multiple reference points with which to compare this study's results. 
Results were also be compared to other studies which had similar elements e.g. Abel \& Kearns (1991), Brabyn \& Skelly (2002), Brabyn \& Beere (2006), Patterson (2009), and Grigg et al (2014), to see if findings were congruent.

Ethics

Ethical approval was gained from the Victoria University of Wellington Human Ethics Committee for this research (Appendix 3).

The 2013 dataset required women's actual residential address to generate point data. This raised ethical issues when seeking approval from the Southern District Health Board for access to such detailed data. The address data were supplied on the condition that they only be available to the student researcher and supervisor and would not be released elsewhere in any form that could enable reidentification of address. Names or NHI numbers of participants were not requested. Access was granted by the Southern District Health Board under the following disclosure rules:

The Health Information Privacy Code (1994) Rule 11(2c) Further Permitted Disclosures states that such information can be disclosed if

(c) the information-

(i) is to be used in a form in which the individual concerned is not identified;

or

(ii) is to be used for statistical purposes and will not be published in a form that could reasonably be expected to identify the individual concerned; 
(iii) is to be used for research purposes (for which approval by an ethics committee, if required, has been given) and will not be published in a form that could reasonably be expected to identify the individual concerned;

(Office of the Privacy Commissioner, 2008, p. 59)

The Survey part of the study requested address data as well as demographic and birth choice questions. An information sheet and completion instructions were attached to the survey questionnaire (Appendix 1) and informed consent was implied by voluntary participation in filling out a questionnaire. The questionnaire was not given to women who suffered a still birth or pregnancy loss.

Ethical approval was given on the basis that any identifiable data during the study would only be shared between the student and supervisor.

\section{Clinical Research Approval and Scientific Peer Review}

While ethical approval was gained through Victoria University of Wellington Human Ethics Committee (Approval \#20256) and the proposal approved by the Graduate School of Nursing, Midwifery and Health Research Committee, local Clinical Research Approval (CRA) was required for this work to be carried out within the Southern District Health Board. A locality assessment was also required to be undertaken for the Health Research South office (Appendix 4). Health Research South is a partnership between the Southern District Health Board and the Dunedin School of Medicine and co-ordinates the approval process of research requiring District Health Board resources and involving their facilities. Requirements of this process were to have a named host investigator for the District Health Board - 
Associate Professor Dr. Michael Stitely kindly acted in this role - and a scientific peer review of the proposal was undertaken (Appendix 5). The District Health Board approval was expedited by the provision of an executive summary to management on the resources required and benefits to the institution and wider community.

\section{Treaty of Waitangi Issues and Māori Consultation}

Respect for the principles of partnership, participation, and protection in the Treaty of Waitangi was observed by consulting with local iwi relating to Māori cultural and ethical values (Health Research Council of New Zealand, 2010) through the Ngāi Tahu Research Consultation Committee at University of Otago (Appendix $6)$.

Ethnicity data was collected as one of the demographic questions in the survey. It was anticipated that choice of birth location may have a correlation to ethnicity (Davis et al., 2011; Ellis, 1998), as issues surrounding place and tūrangawaewae are a central tenant in Māori health (Durie, 2001). It is therefore crucial that tāngata whenua were consulted in relation to this research. 


\section{Chapter 4 - Findings}

The findings of this research reflect the two-stage structure of the project. Due to the rich nature of the data obtained and methodologies available, geographical analysis was split into three phases: descriptive, predictive, and exploratory. While the survey section was limited by small urban response rates, results obtained were congruent with other similar research projects e.g. Grigg et al (2014).

\section{Spatial Analysis}

A dataset of all live births in Southern District Health Board maternity facilities was obtained for $2013(n=3283)$. This included fourteen women from outside the Southern District Health Board (ranging from Auckland to Timaru) who had transferred into the District for clinical reasons. These fourteen women were excluded in the service area and nearest facility analyses.

Table 7: 2013 Actual births per facility \& birthing women closest to facility - Southern DHB

\begin{tabular}{|l|r|r|}
\hline Facility & Actual Births & Nearest Facility \\
\hline Charlotte Jean (Alexandra) & 64 & 169 \\
Clutha Health (Balclutha) & 33 & 144 \\
Queen Mary - Dunedin & 1652 & 1123 \\
Gore & 87 & 223 \\
Lakes District (Queenstown) & 46 & 345 \\
Lumsden & 21 & 83 \\
Oamaru & 102 & 230 \\
Southland Hospital & 1219 & 732 \\
Tuatapere & 18 & 49 \\
Winton & 40 & 137 \\
Ranfurly & 1 & 34 \\
\hline Grand Total & 3283 & 3269 \\
\hline
\end{tabular}




\section{Distances}

Distances here are the actual driving distances (not straight-line distance) between the woman's residential address and her birth place. These exclude the fourteen 'out of District Health Board' women.

$\begin{array}{ll}\text { Mean: } & 51.7 \mathrm{~km} \\ \text { Median } & 11.2 \mathrm{~km} \\ \text { Standard Deviation: } & 74.5 \mathrm{~km} \\ \text { Range: } & 75 \mathrm{~m} \text { to } 335 \mathrm{~km}\end{array}$

\section{Outliers}

- 517 women out of the 3283 who gave birth in 2013 lived more than 120 minutes from a complex care hospital $(16 \%)$

- 53 women lived more than 60 minutes from ANY unit (2\%)

- 4 women lived more than 120 minutes from ANY unit $(0.12 \%)$

\section{Complex Care Units}

For the purposes of this study, Southland Hospital in Invercargill (sometimes known as Kew Hospital) and Queen Mary Maternity Centre at Dunedin Hospital are defined as complex care units. Each provides a range of services as specified in the Ministry of Health Secondary and Tertiary maternity services Service specification (2011). Invercargill is a secondary unit and Queen Mary a tertiary one - the main difference being the availability of a Neonatal Intensive care unit in Dunedin and round-the-clock onsite obstetric and paediatric staff. These two units also are the only sites that can provide epidural anaesthesia and caesarean sections (planned or emergency), and are staffed by a medical obstetric and paediatric teams as well as 
midwives. Therefore, these units serve a large catchment or service area. Figure 10 shows 30, 60 and 120 minute drive time service areas.

Figure 10: 30, 60 and 120 minute service areas (drive time) Invercargill and Dunedin Complex Maternity Units

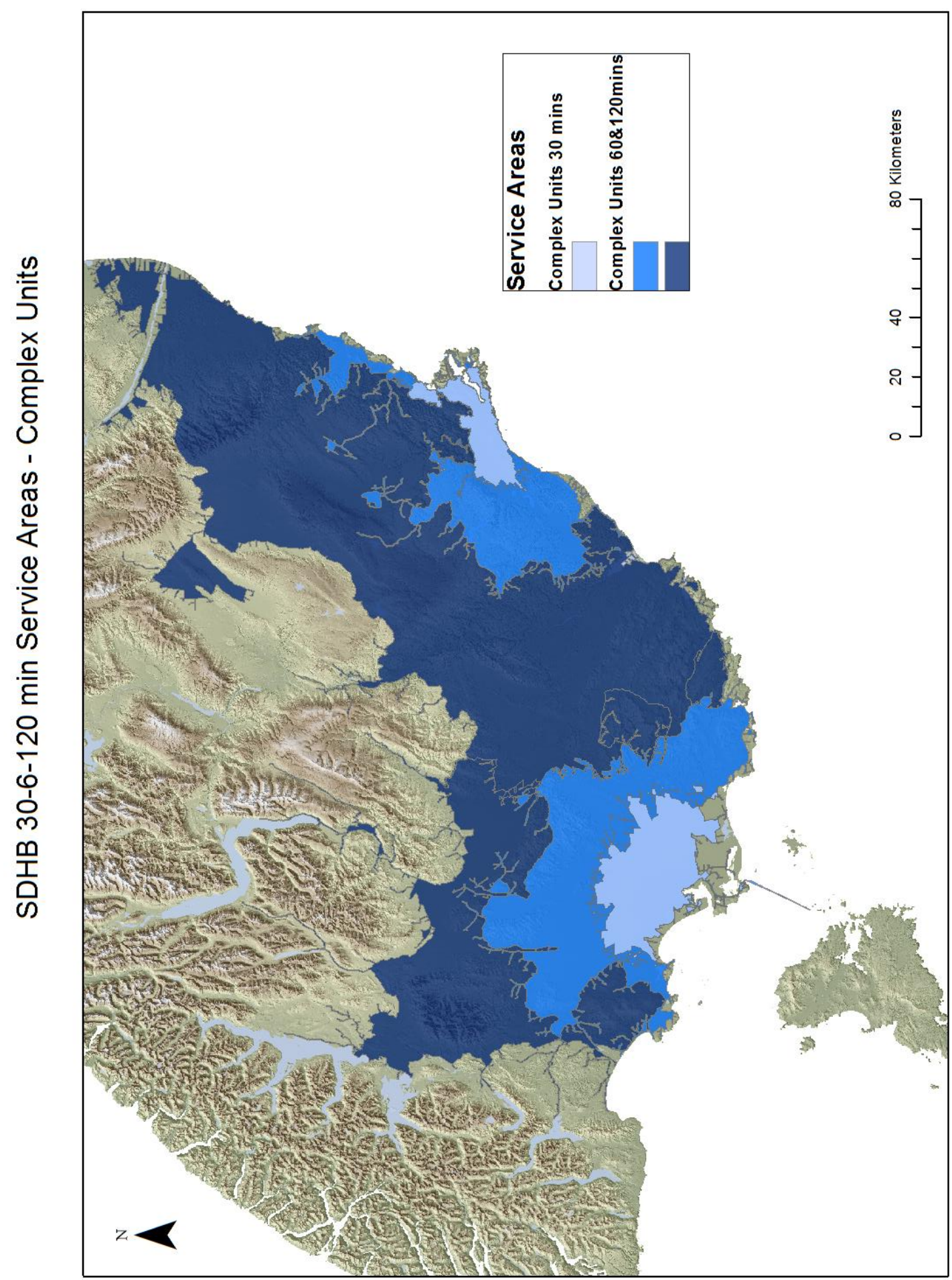




\section{Primary Facility Potential}

Service areas were also created around each Southern District Health Board primary maternity facility that represented a thirty minute actual drive time (Figure 11). Primary maternity units are provisioned in accordance with a Ministry service coverage schedule as follow:

“DHB Funded Primary Maternity Facility (tier two), including in urban areas or rural communities with a catchment of 200 pregnancies where the facility is 30 minutes from a secondary service, and with a catchment of 100 pregnancies where the facility is 60 minutes from a secondary service" (Ministry of Health, 2014a, p. 30). 


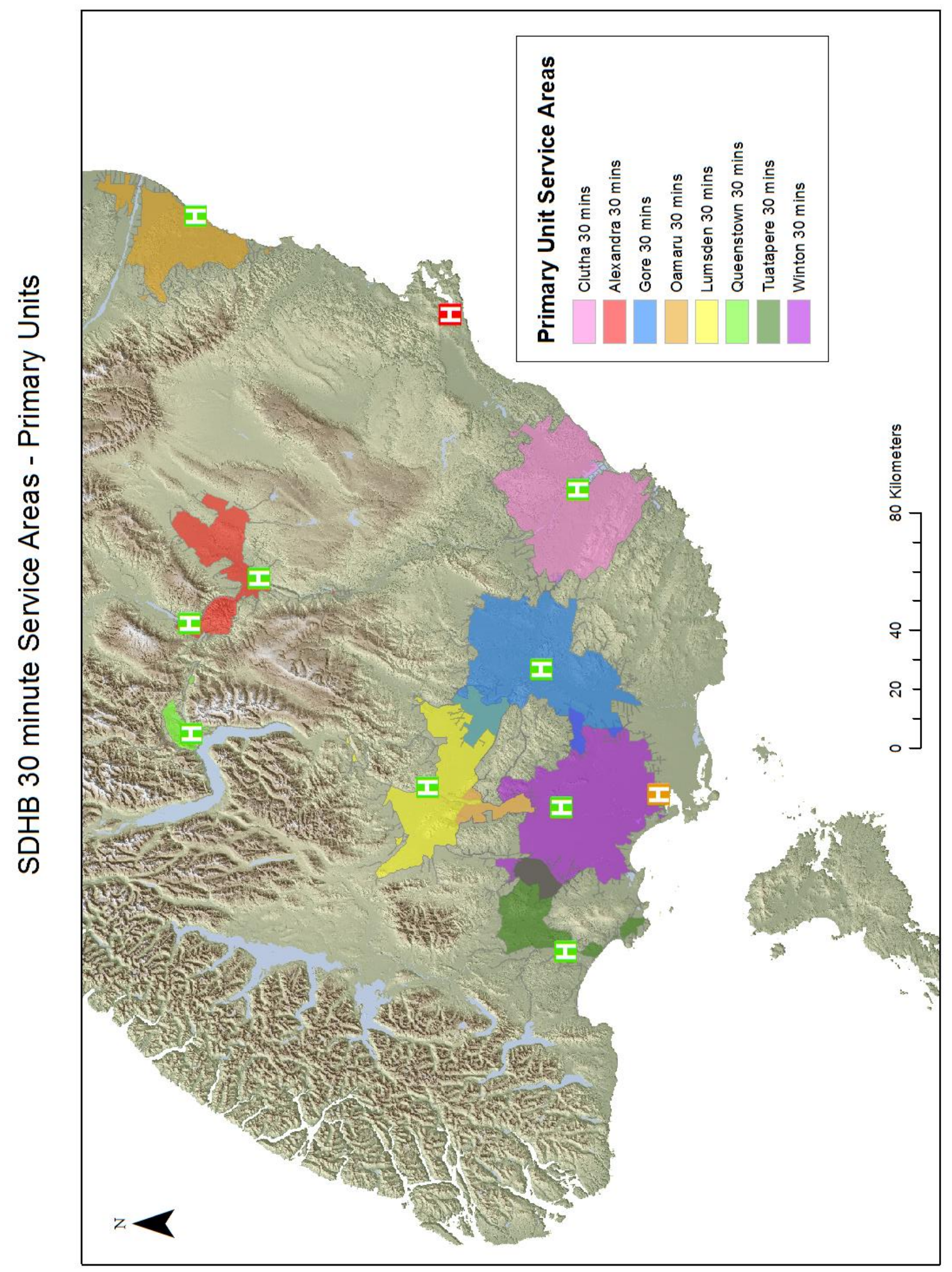

The number of women who gave birth in 2013 that lived within each service area was calculated and compared with the number of births that actually took place at the maternity unit. It is acknowledged that some women require the clinical care 
services of the larger secondary and tertiary units (Invercargill and Dunedin) so the number of women within the thirty minute service area or catchment was adjusted by 65\%. In 2011 the Southern District Health Board had a 65\% spontaneous vaginal birth rate defined as "a vaginal birth without obstetric intervention" (Ministry of Health, 2014c) so potentially $65 \%$ of women did not require higher level maternity services. The adjustment was not made for Southland (Invercargill) and Queen Mary (Dunedin) as they both offered complex care services.

Table 8: Facility, 30 minute service area populations, actual births and adjusted potential

\begin{tabular}{|l|r|r|r|r|}
\hline Facility & 30min & Actual births 2013 & $\begin{array}{c}\text { adjusted } \\
\text { potential'65\% }\end{array}$ & $\begin{array}{c}\text { \% of potential } \\
\text { achieved }\end{array}$ \\
\hline Oamaru & 215 & 102 & 140 & $73 \%$ \\
\hline Ranfurly & 11 & 1 & 7 & $14 \%$ \\
\hline Alexandra & 147 & 64 & 96 & $67 \%$ \\
\hline Queenstown & 235 & 46 & 153 & $30 \%$ \\
\hline Gore & 208 & 87 & 135 & $64 \%$ \\
\hline Clutha & 127 & 33 & 83 & $40 \%$ \\
\hline Lumsden & 61 & 21 & 40 & $53 \%$ \\
\hline Winton & 611 & 40 & 397 & $10 \%$ \\
\hline Tuatapere & 53 & 18 & 34 & $52 \%$ \\
\hline Kew & 761 & 1219 & $\mathrm{n} / \mathrm{a}$ & $\mathrm{n} / \mathrm{a}$ \\
\hline Queen Mary & 1077 & 1652 & $\mathrm{n} / \mathrm{a}$ & $\mathrm{n} / \mathrm{a}$ \\
\hline
\end{tabular}

It can be seen that some primary units reached closer to their potential numbers than others, with Oamaru at $73 \%$ of potential. Units close to urban areas, such as Winton, had their service area strongly overlap that of a larger complex care facility and so the population within the thirty minute service area is somewhat misleading.

\section{Geographic Service Inequality}

While there areas of significant service area overlap in some regions of the District Health Board, other areas have relatively limited service coverage. Marginal

\footnotetext{
${ }^{4}$ This report categorised epidural pain relief as an obstetric intervention (Ministry of Health, 2014c).
} 
service areas with limited coverage are most evident in the greater Wanaka/Hawea area. This area has had significant growth in the last decade. The 2013 Census states that 5,037 people usually live in Wanaka and 2,175 in Hawea, an increase of 51.3\% since the 2001 Census (Statistics New Zealand, 2014d). This trend is set to continue with a large new subdivision having just been approved, which is estimated to increase the population of the area by another 50\% (Ibbotson, 2014a, 2014b).

Currently these more semi-urban population areas of Wanaka and Hawea are right on the edge of sixty minute services areas from two primary maternity units Charlotte Jean Maternity in Alexandra and Lakes Hospital in Queenstown. It should be noted that the sixty minute service area extending from Queenstown is via the Crown Range Road, the highest sealed main road in New Zealand climbing to an altitude of $1,076 \mathrm{~m}$ above sea level. During winter the road is subject to snow, and chains are frequently essential to cross it (McKinnon, 2012). Figure 12 also shows that these service area cut-offs can be somewhat arbitrary e.g. the Lakes Hospital sixty minute cut-off runs through the centre of Wanaka township. Wanaka is over 3.5 hours' drive from both Dunedin and Invercargill and 114 women from the Wanaka/Hawea area gave birth in 2013. 
Figure 12: 60 minute maternity service areas that cover Wanaka and Hawea

Wanaka and Hawea with 60 minute boundaries

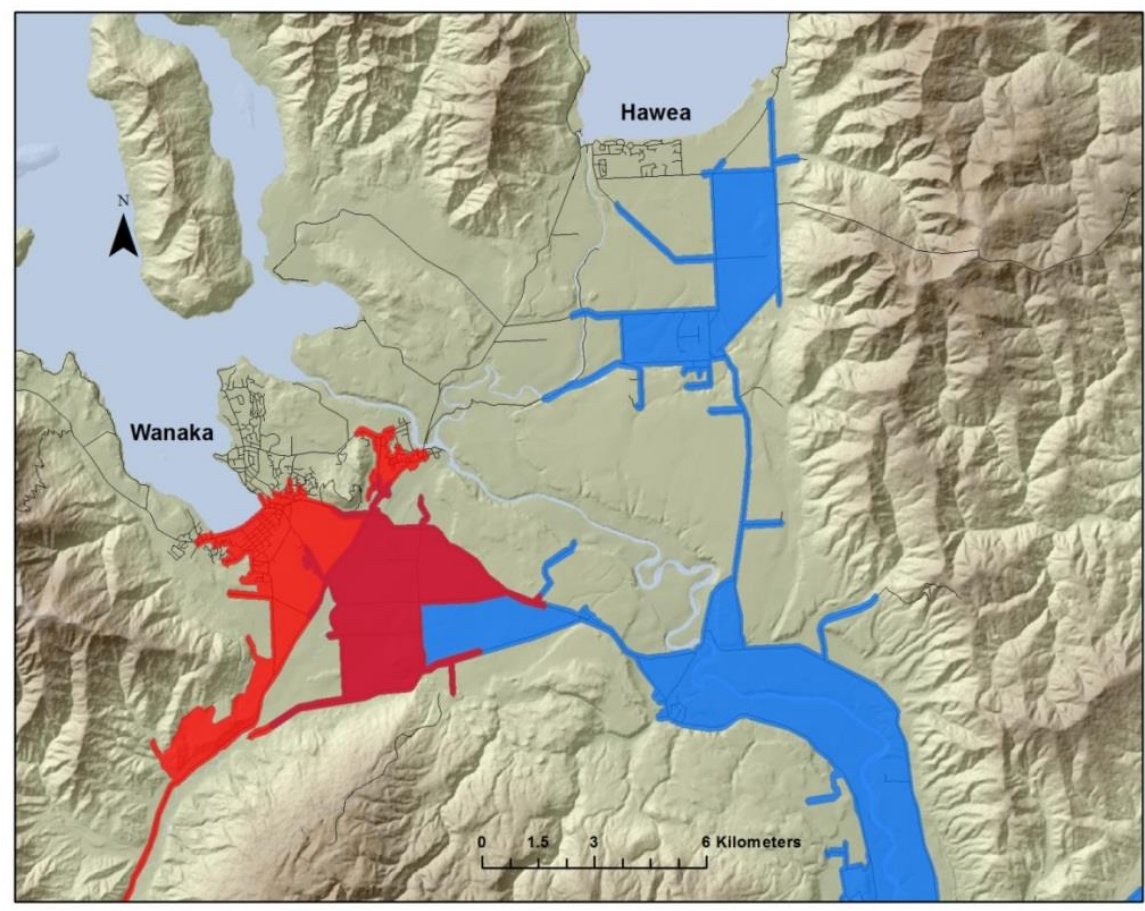

Drive Times

To Queenstown

60 mins

To Alexandra

60 mins

From Table 5, it can be seen that primary units that are more distant from a complex care unit have great variance in meeting potential birth numbers: for example, Queenstown Lakes District Hospital (approximately 2.5 hours from Invercargill) in comparison to Oamaru (approximately 1.5 hours from Dunedin). With these drive times, travel impedance would suggest that more women would birth locally in the Queenstown service area. However Table 9 and Figures 13 \& 14 show this is not the case.

Table 9: Where women within a 30 minute drive time service area of each primary facility actually birthed

\begin{tabular}{|l|r|r|r|r|r|r|r|r|r|r|r|}
\hline \multicolumn{1}{|c|}{ Actual Place of Birth } \\
\hline 30min SA of & Alexandra & Clutha & Gore & Southland & Lakes & Lumsden & Oamaru & Queen Mary & Tuatapere & Winton & Ranfurly \\
\hline Alexandra & $21.77 \%$ & & & $2.04 \%$ & & & & $76.19 \%$ & & & \\
\hline Lakes & $1.28 \%$ & & & $\mathbf{6 8 . 9 4} \%$ & $18.72 \%$ & $1.28 \%$ & & $9.79 \%$ & & & \\
\hline Ranfurly & $9.09 \%$ & & & & & & & $\mathbf{8 1 . 8 2} \%$ & & & $9.1 \%$ \\
\hline Lumsden & & & $14.75 \%$ & $\mathbf{5 4 . 1 0} \%$ & & $19.67 \%$ & & $1.64 \%$ & & $9.84 \%$ & \\
\hline Balclutha & & $22.05 \%$ & & $3.94 \%$ & & & & $74.02 \%$ & & & \\
\hline Tuatapere & & & & $\mathbf{7 3 . 5 8} \%$ & & & & & $20.75 \%$ & $5.66 \%$ & \\
\hline Oamaru & & & & & & & $43.72 \%$ & $\mathbf{5 6 . 2 8} \%$ & & & \\
\hline Winton & & & & $\mathbf{9 2 . 6 4} \%$ & & & & $1.15 \%$ & $0.49 \%$ & $5.73 \%$ & \\
\hline Gore & $0.48 \%$ & & $35.58 \%$ & $\mathbf{5 8 . 6 5 \%}$ & & $1.92 \%$ & & $2.40 \%$ & & $0.96 \%$ & \\
\hline
\end{tabular}


Figure 13: Where women who lived within 30 minutes of Queenstown gave birth in 2013

\section{3 - women living within a $\mathbf{3 0}$ minute drive of Lakes Hospital (Queenstown)}

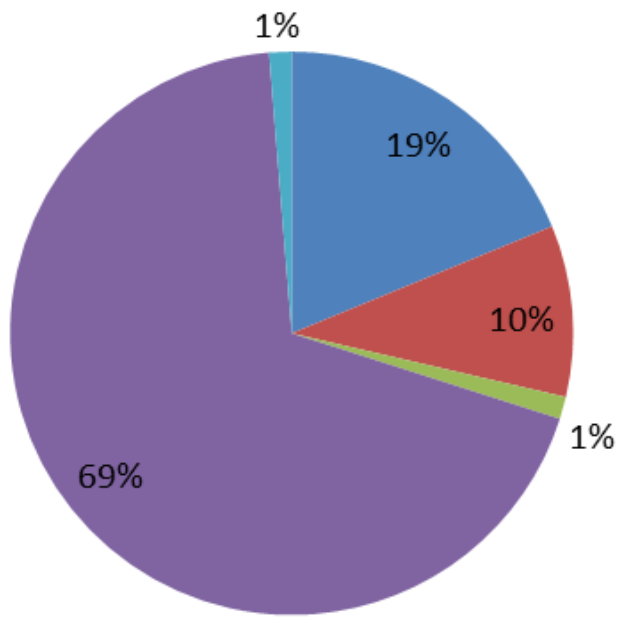

Actual Birthplace

- Lakes

Dunedin

Charlotte Jean (Alexandra)

- Invercargill

- Lumsden

Figure 14: Where women who lived within 30 minutes of Oamaru gave birth in 2013

\section{3 - women living within a $\mathbf{3 0}$ minute drive of Oamaru Maternity}

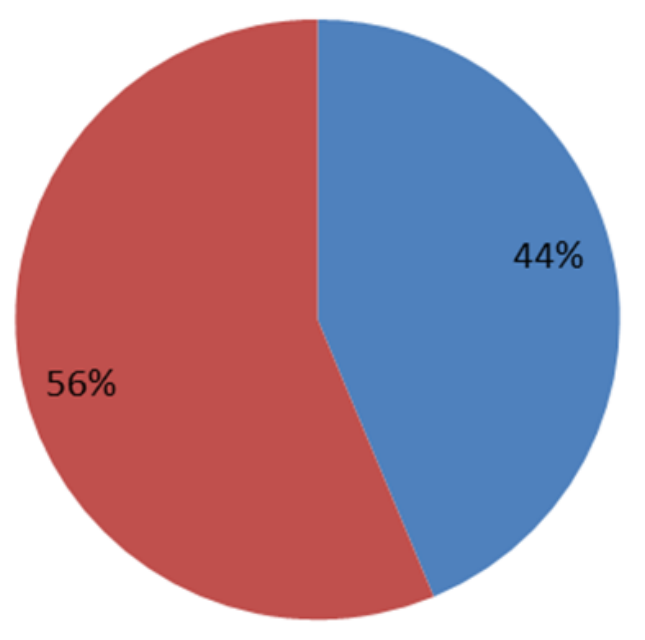

Actual Birthplace

- Oamaru

Dunedin 


\section{Predictive Analysis - Gravity Modelling}

Of the various spatial models that could be applied to healthcare access and utilisation, Reilly's law (as a basis) and Huff modelling were selected, as discussed in the methodology section. The outcomes of these models were compared to actual travel in an effort to assess what sort of relationship birthplace choice had with geospatial reasoning.

\section{Reilly's Law}

Reilly's Law attempts to predictively determine the gravity between two places and calculates the cut-off point between them when the gravity of one site is equivalent to another. This is known as the Point of Indifference. Reilly's Law in its basic form simply looks at the population of two sites to calculate the point between the sites where one place ceases to be attractive as a destination in comparison to the second.

For example using Invercargill and Lumsden:

$$
\begin{aligned}
\mathrm{M}_{\mathrm{ab}} & =80 /(1+\sqrt{ }(405 / 51696) \\
& =80 / 1.088511366 \\
& =73.50 \mathrm{~km}
\end{aligned}
$$

So the point of indifference is $73.50 \mathrm{~km}$ from Invercargill or only $6.5 \mathrm{~km}$ from Lumsden where Lumsden ceases to be an attractive destination (Figure 15). After this point Invercargill has more gravity. 
Figure 15: Reilly's Law. Lumsden to Invercargill

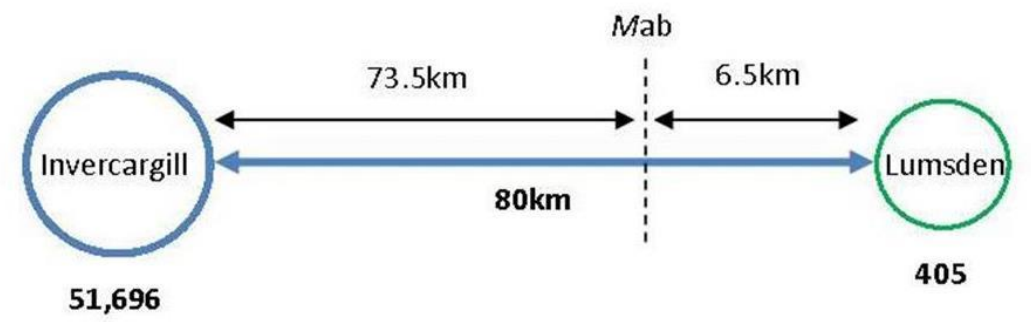

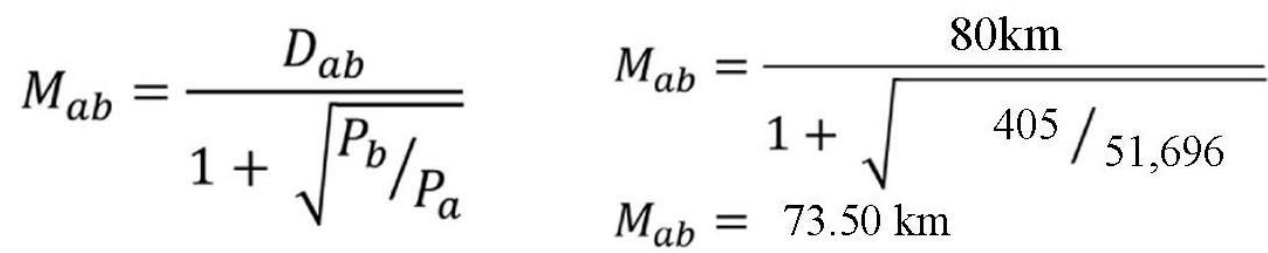

This could also (and possibly more accurately) be calculated using actually birth facility numbers rather than total populations. For example:

$$
\begin{aligned}
\mathrm{M}_{\mathrm{ab}} & =80 /(1+\sqrt{ }(21 / 1219) \\
& =80 / 1.131252564 \\
& =70.72 \mathrm{~km}
\end{aligned}
$$

Point of indifference (for birthing) $=70.72 \mathrm{~km}$ from Invercargill or $9.28 \mathrm{~km}$ from Lumsden

Using the same method the point between Alexandra (Charlotte Jean Maternity) and Dunedin could be calculated as follows:

$$
\begin{aligned}
\mathrm{M}_{\mathrm{ab}} & =190 /(1+\sqrt{ }(4800 / 120249) \\
& =190 / 1.199792822 \\
& =158.36 \mathrm{~km}
\end{aligned}
$$

Point of indifference is $158.36 \mathrm{~km}$ from Dunedin or only $31.64 \mathrm{~km}$ from Alexandra. 
And using actual 2013 birth numbers

$$
\begin{aligned}
\mathrm{M}_{\mathrm{ab}} & =190 /(1+\sqrt{ }(64 / 1652) \\
& =190 / 1.196827133 \\
& =158.75 \mathrm{~km}
\end{aligned}
$$

Point of indifference is $158.75 \mathrm{~km}$ from Dunedin or only $31.25 \mathrm{~km}$ from Alexandra (Figure 16).

Figure 16: Reilly's Law. Alexandra to Dunedin

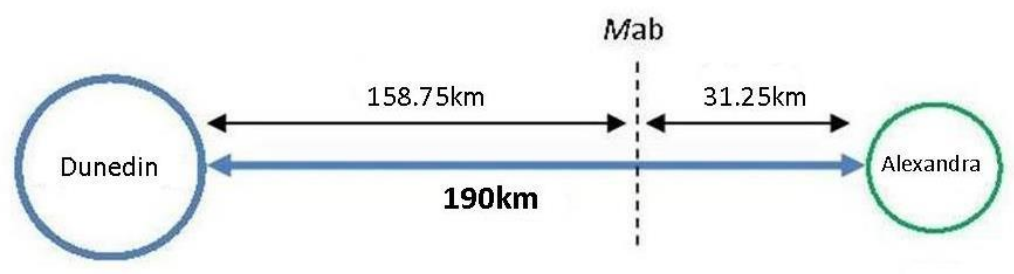

$$
M_{a b}=\frac{D_{a b}}{1+\sqrt{P_{b} / P_{a}}} \quad M_{a b}=\frac{190}{1+\sqrt{64 / 1652}}
$$

This very simple model only works between two points. However, it can be tested against the 2013 travel dataset in this thesis.

ArcGIS tools were used to select all women living along the main road (State Highway 8) between Alexandra and Dunedin with a 500m buffer to include homes set back a little from the highway. This highway is the equivalent of point to point line of the Reilly model. From this selection, of the women that chose to birth at Charlotte Jean Maternity, the furthest away was approximately $30 \mathrm{~km}$ south (towards 
Dunedin). After that point all women choose to travel to Dunedin or Invercargill. Using the same methodology and based on birth numbers at each unit, the break points or 'point of indifference' were calculated for other primary units and compared to the actual 2013 break points, as shown in Table 10 below.

Table 10: Break Points or 'Point of Indifference' between Maternity Facilities in kilometres ${ }^{5}$

\begin{tabular}{|l|l|r|r|r|r|r|r|}
\hline Primary(a) & Complex Care $(\mathrm{b})$ & Births(a) & Births(b) & Distance $(\mathrm{km})$ & Break Point b $(\mathrm{km})$ & Break point a $(\mathrm{km})$ & Actual Break \\
\hline Oamaru & Dunedin & 102 & 1652 & 112 & 89.71 & 22.29 & 19 \\
\hline Alexandra & Dunedin & 64 & 1652 & 190 & 158.75 & 31.25 & 30 \\
\hline Queenstown & Invercargill & 46 & 1219 & 187 & 156.58 & 30.42 & 5 \\
\hline Gore & Invercargill & 87 & 1219 & 65 & 51.30 & 13.70 & 12 \\
\hline Clutha & Duendin & 33 & 1652 & 80 & 70.09 & 9.91 & 21 \\
\hline Lumsden & Invercargill & 21 & 1219 & 80 & 70.72 & 9.28 & 12 \\
\hline Winton & Invercargill & 40 & 1219 & 30 & 25.40 & 4.60 & 14 \\
\hline Tuatapere & Invercargill & 18 & 1219 & 81 & 72.22 & 8.78 & 8 \\
\hline
\end{tabular}

\section{Huff Model}

For further complex analysis and a more pragmatic approach, the Huff model was implemented.

The Huff model was run for all the 2013 residential points of birthing women and related to all maternity facilities in the Southern District Health Board. The parameters for the Huff model were Euclidean distance (straight-line or "as the crow flies") as travel impedance and a weighting for each facility.

Running the model produced a probability that each individual might attend any given maternity facility. While this was run for all the residential points (excluding the fourteen 'out of District Health Board' women), to preserve individual anonymity, only examples from more urban areas (e.g. built-up residential areas rather than rural farms) have been included in Table 11 below and compared to actual 2013 birth place figures in Table 12.

\footnotetext{
${ }^{5}$ Ranfurly not included as it is no longer an active birth centre
} 
Table 11: Huff Model. Probability of attending any SDHB maternity unit based on town of residence

\begin{tabular}{|c|c|c|c|c|c|c|c|c|c|c|c|}
\hline Town & Alexandra & Clutha & Gore & Kew & Lakes & \begin{tabular}{|l|} 
Lumsden \\
\end{tabular} & Oamaru & Queen Mary & \begin{tabular}{|l|} 
Tuatapere \\
\end{tabular} & Winton & Best Fit \\
\hline Dunedin & \begin{tabular}{|l|}
$0.01 \%$ \\
\end{tabular} & $0.03 \%$ & $0.01 \%$ & $0.02 \%$ & $0.01 \%$ & \begin{tabular}{|l|}
$0.01 \%$ \\
\end{tabular} & \begin{tabular}{|l|}
$0.02 \%$ \\
\end{tabular} & $99.85 \%$ & \begin{tabular}{|l|}
$0.00 \%$ \\
\end{tabular} & $0.01 \%$ & Queen Mary \\
\hline Invercargill & $0.07 \%$ & $0.13 \%$ & $0.48 \%$ & $96.17 \%$ & $0.06 \%$ & $0.28 \%$ & $0.02 \%$ & $0.19 \%$ & $0.44 \%$ & $2.07 \%$ & Kew Hospital \\
\hline Winton & $1.22 \%$ & $1.45 \%$ & $9.79 \%$ & $18.19 \%$ & $1.21 \%$ & $17.21 \%$ & $0.31 \%$ & $2.32 \%$ & $3.99 \%$ & $42.48 \%$ & Winton \\
\hline Lumsden & $2.91 \%$ & $1.33 \%$ & $4.09 \%$ & $6.83 \%$ & $4.77 \%$ & $63.45 \%$ & $0.49 \%$ & $3.03 \%$ & $3.07 \%$ & $5.26 \%$ & Lumsden \\
\hline Alexandra & $99.13 \%$ & $0.02 \%$ & $0.02 \%$ & $0.03 \%$ & $0.06 \%$ & $0.02 \%$ & $0.01 \%$ & $0.07 \%$ & $0.01 \%$ & $0.01 \%$ & Charlotte Jean \\
\hline Queenstown & $0.88 \%$ & $0.12 \%$ & $0.20 \%$ & $0.35 \%$ & $94.96 \%$ & $0.42 \%$ & $0.10 \%$ & $0.44 \%$ & $0.14 \%$ & $0.18 \%$ & Lakes District \\
\hline Cromwell & $20.74 \%$ & $1.09 \%$ & $1.41 \%$ & $2.21 \%$ & $14.01 \%$ & $2.08 \%$ & $1.24 \%$ & $4.68 \%$ & $0.74 \%$ & $1.05 \%$ & Charlotte Jean \\
\hline Wanaka & $15.42 \%$ & $2.35 \%$ & $2.82 \%$ & $5.14 \%$ & $20.27 \%$ & $4.00 \%$ & $3.82 \%$ & $11.03 \%$ & $1.81 \%$ & $2.31 \%$ & Lakes District \\
\hline Balclutha & $0.05 \%$ & $98.85 \%$ & $0.16 \%$ & $0.16 \%$ & $0.03 \%$ & $0.05 \%$ & $0.03 \%$ & $0.51 \%$ & $0.03 \%$ & $0.05 \%$ & Clutha Health First \\
\hline Tuatapere & $0.09 \%$ & $0.10 \%$ & $0.25 \%$ & $1.71 \%$ & $0.12 \%$ & $0.45 \%$ & $0.03 \%$ & $0.20 \%$ & $96.02 \%$ & $0.88 \%$ & Tuatapere \\
\hline Oamaru & $3.83 \%$ & $1.68 \%$ & $1.28 \%$ & $2.26 \%$ & $1.94 \%$ & $1.18 \%$ & $51.33 \%$ & $15.86 \%$ & $0.64 \%$ & $0.88 \%$ & Oamaru \\
\hline Gore & $2.04 \%$ & $3.02 \%$ & $56.73 \%$ & $10.91 \%$ & $1.46 \%$ & $9.45 \%$ & $0.44 \%$ & $3.91 \%$ & $1.85 \%$ & $7.39 \%$ & Gore \\
\hline Te Anau & $5.24 \%$ & $2.64 \%$ & $5.78 \%$ & $15.79 \%$ & $11.84 \%$ & $19.93 \%$ & $1.32 \%$ & $6.97 \%$ & $11.88 \%$ & $9.35 \%$ & Lumsden \\
\hline
\end{tabular}

Table 12: Huff Model vs Actual travel 2013

\begin{tabular}{|c|c|c|c|c|c|c|c|c|c|c|c|c|}
\hline & Actual & Huff Model & Actual & Huff Model & Actual & Huff Model & Actual & Huff Model & Actual & Huff Model & Actual & Huff Model \\
\hline Facility & \multicolumn{2}{|c|}{ Alexandra } & \multicolumn{2}{|c|}{ Queenstown } & \multicolumn{2}{|c|}{ Lumsden } & \multicolumn{2}{|c|}{ Clutha } & \multicolumn{2}{|c|}{ Tuatapere } & \multicolumn{2}{|c|}{ Oamaru } \\
\hline Alexandra & $21.77 \%$ & $99.13 \%$ & $1.28 \%$ & $0.88 \%$ & & $2.91 \%$ & & $0.05 \%$ & & $0.09 \%$ & & $3.83 \%$ \\
\hline Clutha & & $0.02 \%$ & & $0.12 \%$ & & $1.33 \%$ & $22.05 \%$ & $98.85 \%$ & & $0.10 \%$ & & $1.68 \%$ \\
\hline Gore & & $0.02 \%$ & & $0.20 \%$ & $14.75 \%$ & $4.09 \%$ & & $0.16 \%$ & & $0.25 \%$ & & $1.28 \%$ \\
\hline Kew & $2.04 \%$ & $0.03 \%$ & $68.80 \%$ & $0.35 \%$ & $54.10 \%$ & $6.83 \%$ & $3.94 \%$ & $0.16 \%$ & $73.58 \%$ & $1.71 \%$ & & $2.26 \%$ \\
\hline Lakes & & $0.06 \%$ & $18.80 \%$ & $94.96 \%$ & & $4.77 \%$ & & $0.03 \%$ & & $0.12 \%$ & & $1.94 \%$ \\
\hline Lumsden & & $0.02 \%$ & $1.28 \%$ & $0.42 \%$ & $19.67 \%$ & $63.45 \%$ & & $0.05 \%$ & & $0.45 \%$ & & $1.18 \%$ \\
\hline Oamaru & & $0.01 \%$ & & $0.10 \%$ & & $0.49 \%$ & & $0.03 \%$ & & $0.03 \%$ & $43.26 \%$ & $51.33 \%$ \\
\hline Queen Mary & $76.19 \%$ & $0.07 \%$ & $9.83 \%$ & $0.44 \%$ & $1.64 \%$ & $3.03 \%$ & $74.02 \%$ & $0.51 \%$ & & $0.20 \%$ & $56.28 \%$ & $15.86 \%$ \\
\hline Tuatapere & & $0.01 \%$ & & $0.14 \%$ & & $3.07 \%$ & & $0.03 \%$ & $20.75 \%$ & $96.02 \%$ & & $0.64 \%$ \\
\hline Winton & & $0.01 \%$ & & $0.18 \%$ & $9.84 \%$ & $5.26 \%$ & & $0.05 \%$ & $5.66 \%$ & $0.88 \%$ & & $0.88 \%$ \\
\hline
\end{tabular}

The causes of the limitations of this model for maternity care can be found in the discussion section and herein the survey results become relevant to such modelling.

\section{Service Provision - Location/Allocation}

All residential points of birthing women within a sixty minute service area of either Lakes Hospital, Charlotte Jean (Alexandra) or central Cromwell were selected for this exercise $(n=535)$. The intent was to find the best position for any new facilities that maybe required due to population expansion in the Wanaka and Hawea areas, as well as the Queenstown Lakes district to the west which expanded $22.9 \%$, between 2006 and 2013 (Statistics New Zealand, 2014c). When positioning a new primary facility, the Ministry of Health guidelines state that in an area such as this it must service a catchment of 100 pregnancies (Ministry of Health \& DHBNZ, 2011). 
The Location-Allocation model was run with a primary facility hypothetically positioned adjacent to the Wanaka Medical Centre and with the Crown Range road blocked from the model due to winter weather restrictions.

Table 13: Potential and adjusted potential births within Central Otago general

\begin{tabular}{|l|r|r|}
\hline Facilities & Potential Births & 65\% Normal Birth adjustment \\
\hline Lakes & 240 & 156 \\
\hline Alexandra & 174 & 113 \\
\hline Wanaka & 113 & 73 \\
\hline Total & 527 & 342 \\
\hline
\end{tabular}

It can also been seen that particularly in this area women appear to be seeking out complex care facilities in which to birth (see Figure 13), and are travelling long distances to achieve this. With the rising populations, not only will maternity facilities be in greater demand but there is potentially a requirement for higher level health care facilities in general.

With this in mind the Location-Allocation model was run based on the premise of a new complex care (likely secondary) health facility being available. The choice of sites here were Queenstown, Alexandra (Dunstan Hospital in Clyde), and a potential new hospital located in Cromwell. The model was run to maximise coverage but all of these sites were evenly weighted as they would provide the same service coverage.

The model ascertained that all the 527 birthing women's residential points from 2013 were within sixty minutes' drive time of Cromwell. Based on the actual 2013 travel patterns, it is likely that a high proportion would select that facility if it had secondary services available. The model actually gave the figure that $100 \%$ of 
women would select it; however as discussed later this is unlikely to occur in practice.

These models were calculated using the actual residential address of women from 2013. To demonstrate the coverage differences between these models, the line data for actual driving distance in kilometres was extrapolated onto radar graphs of equal scale, with all geographic data removed to preserve anonymity of the women. These graphs (Figures 17, 18, $19 \& 20$ ) indicate distribution for each facility on the same scale at $20 \mathrm{~km}$ increments and actual birth journey lengths, but evenly distributed around a $360^{\circ}$ axis for obfuscation purposes. The centre of each radar chart is the maternity facility and the end of each line is the demand-point i.e. the women's residential address.

Figure 17: The women who would potentially access Queenstown Lakes Primary Maternity unit based on a 60 minute drive time and 2013 birth data

\section{Lakes Hospital - Queenstown (existing)}

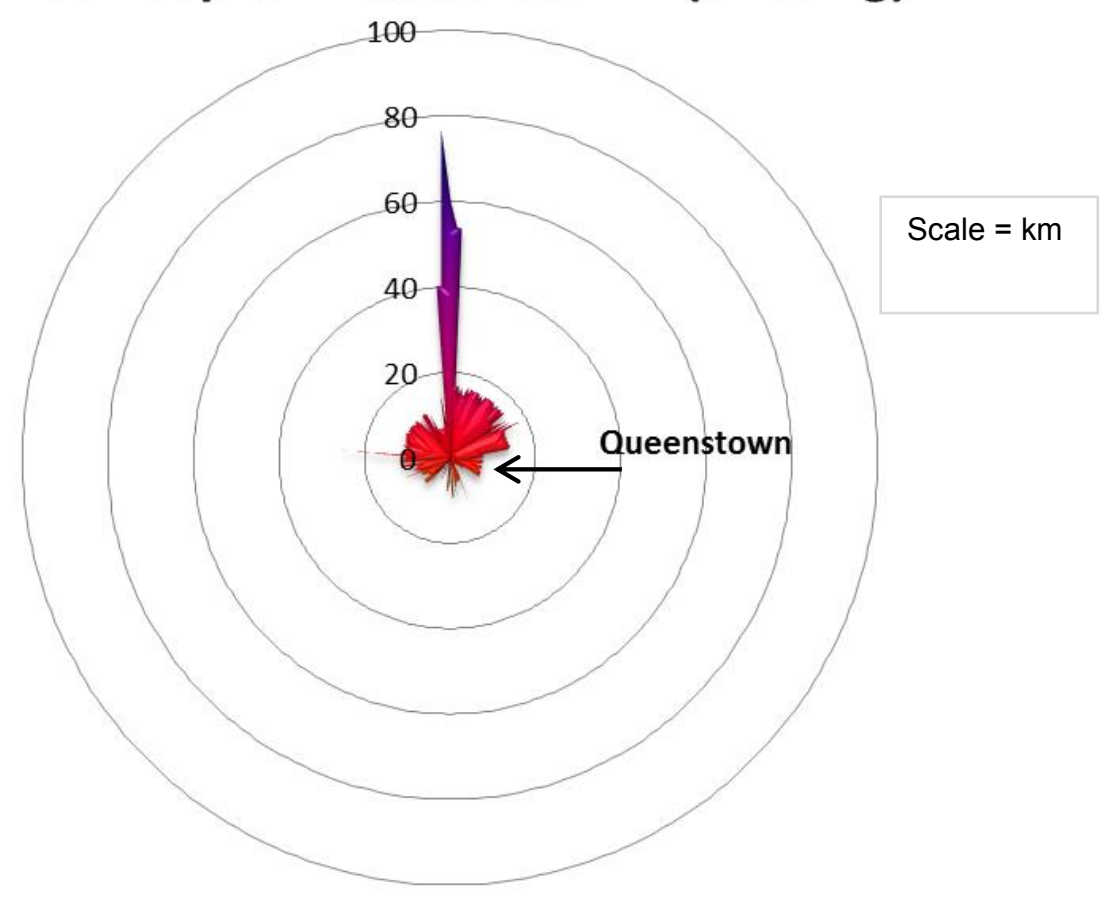


Figure 18: The women who would potentially access Charlotte Jean Primary Maternity unit based on a 60 minute drive time and 2013 birth data

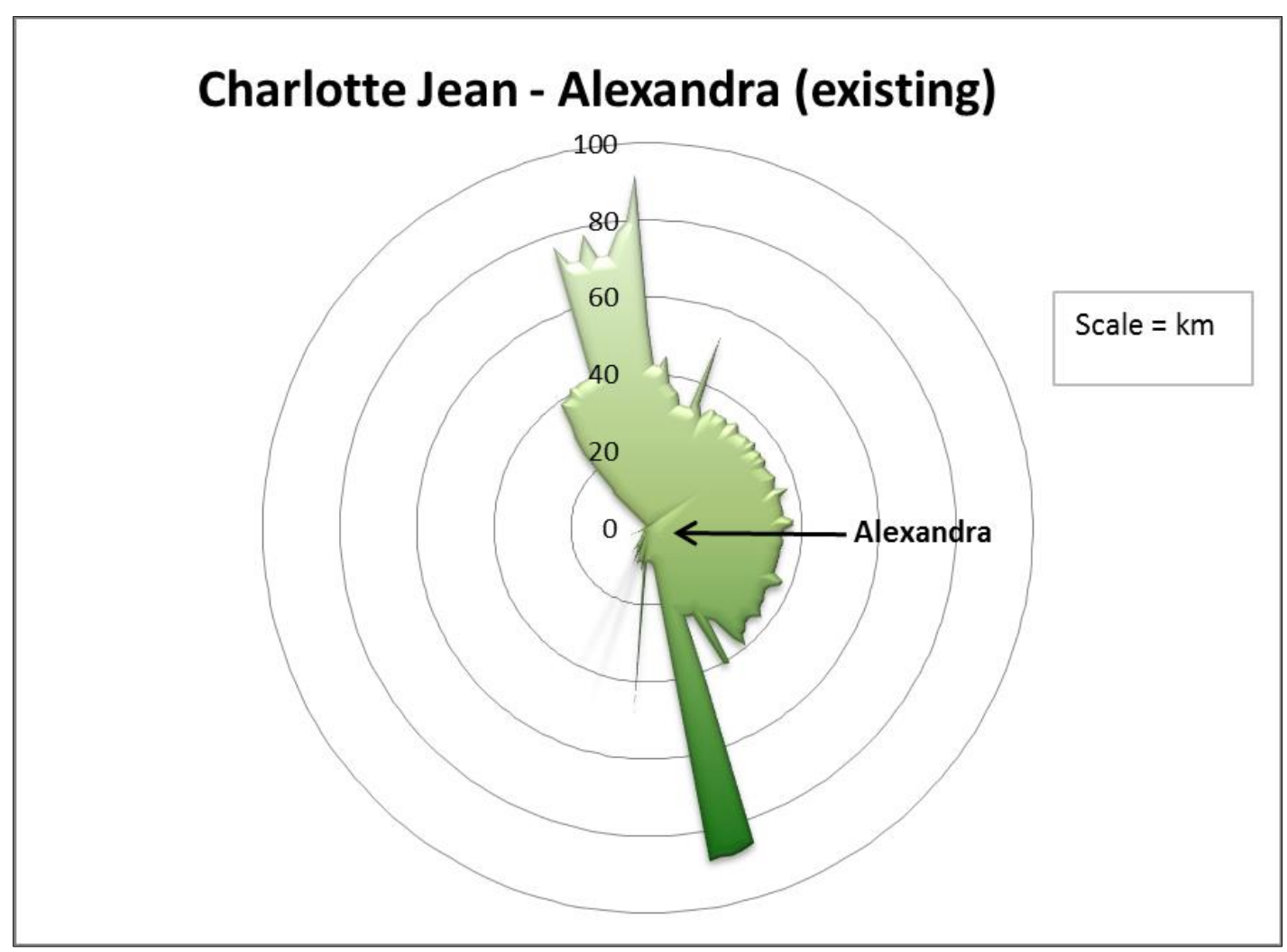

Figure 19: The women who would potentially access a new Primary Maternity unit in Wanaka based on a 60 minute drive time and 2013 birth data

\section{Potential Site - Wanaka (Primary)}

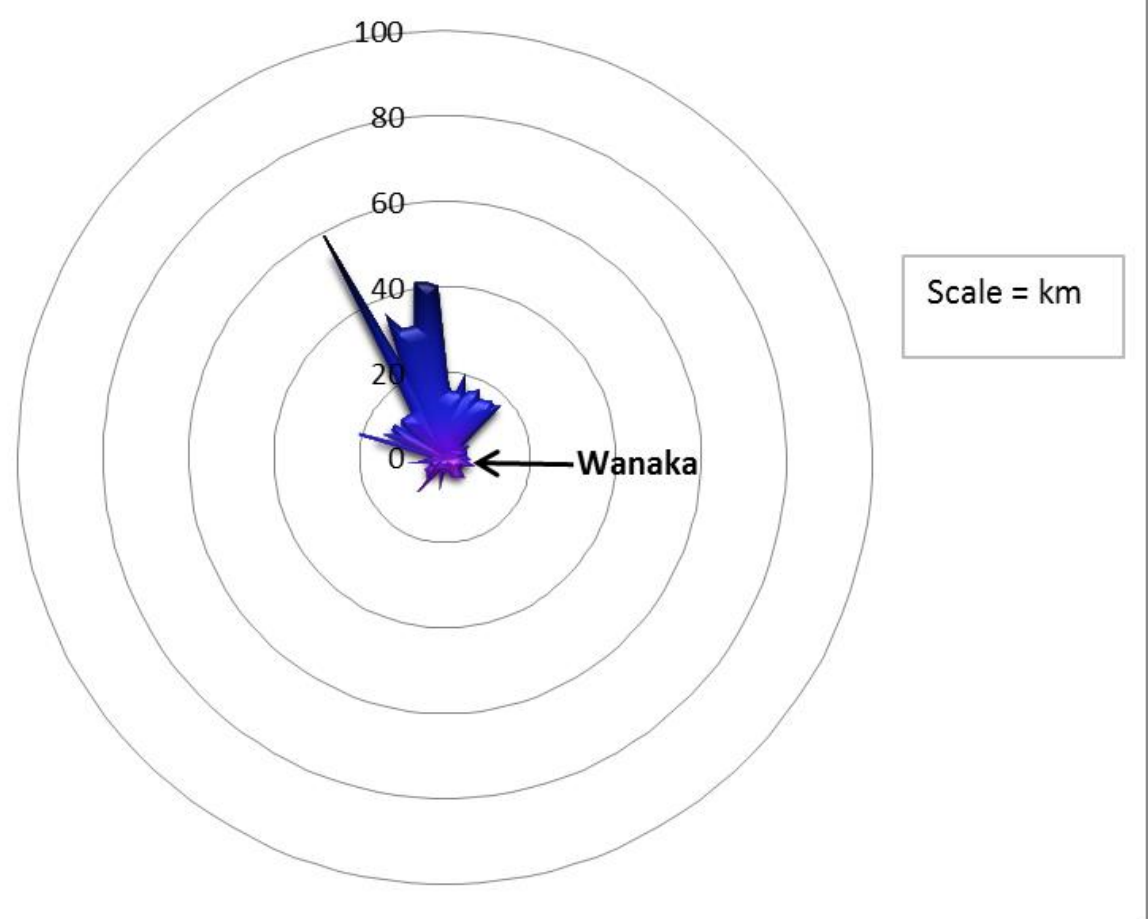


Figure 20: The women who would potentially access a new Secondary Maternity in Cromwell unit based on a 60 minute drive time and 2013 birth data

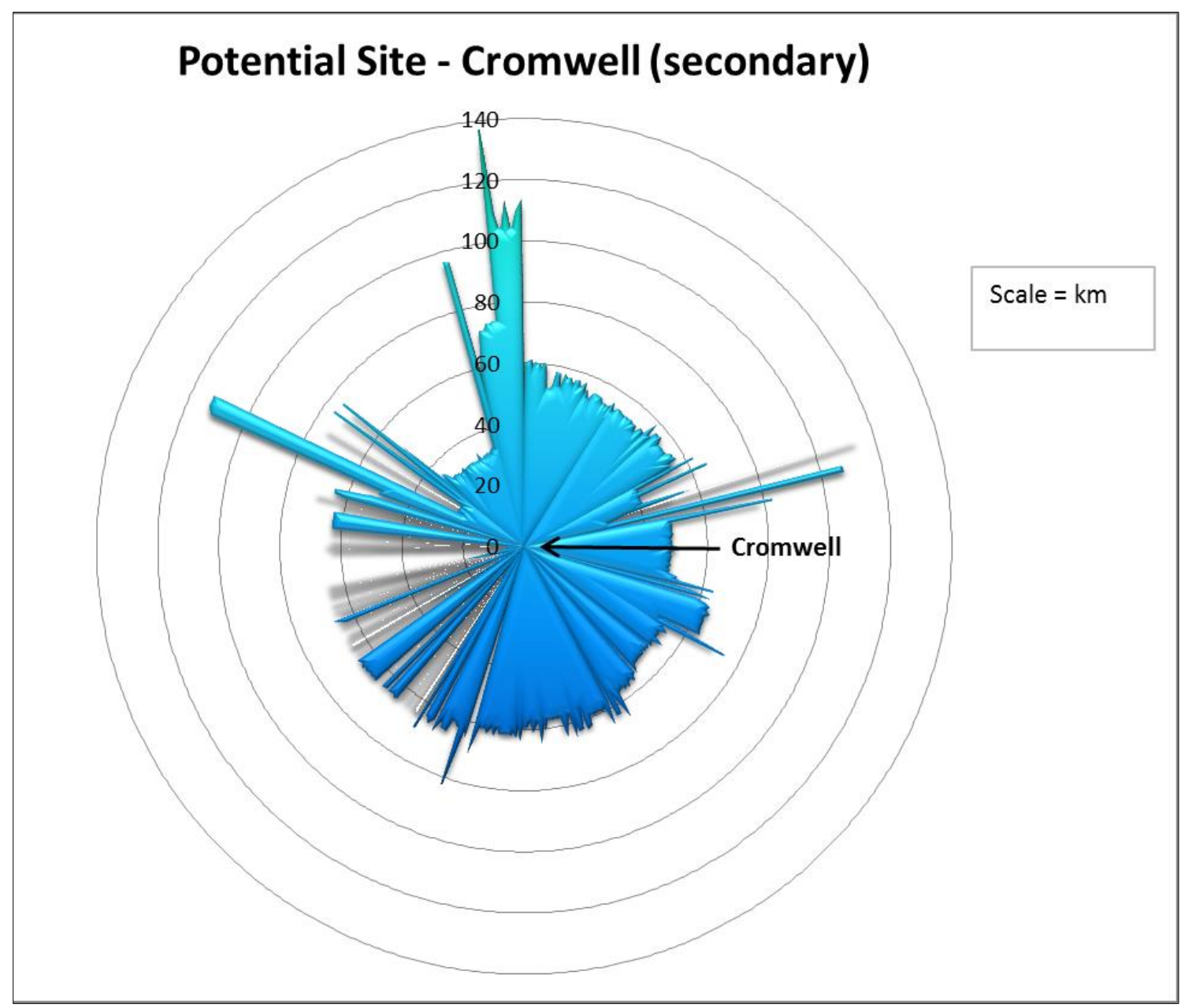




\section{Survey Findings}

The paper-based survey was administered in all maternity facilities within the Southern District Health Board during April, May and June 2014. Surveys were also offered to women birthing at home, through their midwives.

\section{Response Rate}

Response rates were variable and for pragmatic reasons around keeping research burden low at each site, no record of how many forms were actually offered to women was kept. Response rate has been calculated on the number of births at the unit, which likely does not equal how many forms were actually offered to women. Two sites also returned forms from women that had birthed at complex care facilities and transferred for postnatal care. These women had not been offered a survey at their place of birth.

Table 14: Survey Response Rates (April, May, June 2014)

\begin{tabular}{|l|r|r|r|}
\hline Unit/Birth Place & Births & llorms Returned & Response Rate \\
\hline Queenstown Lakes & 22 & 11 & $50 \%$ \\
\hline Charlotte Jean & 10 & 7 & $70 \%$ \\
\hline Oamaru & 16 & 5 & $31 \%$ \\
\hline Invercargill & 323 & 27 & $\mathbf{8 \%}$ \\
\hline Lumsden & 4 & $5^{*}$ & $100 \%$ \\
\hline Winton & 10 & 8 & $80 \%$ \\
\hline Tuatapere & 2 & $3^{*}$ & $100 \%$ \\
\hline Gore & 16 & 9 & $56 \%$ \\
\hline Clutha & 6 & 5 & $83 \%$ \\
\hline Dunedin & 409 & 81 & $20 \%$ \\
\hline Home & 14 & 4 & $29 \%$ \\
\hline TOTAL & $\mathbf{8 3 2}$ & $\mathbf{1 6 5}$ & $\mathbf{2 0 \%}$ \\
\hline
\end{tabular}

* Included forms from postnatal stay only women

\section{Demographics of the sample}

The demographic variables of the survey sample were compared with data extracted from the 2013 Maternity Tables for the Southern District Health Board 
(Ministry of Health, 2013) and 2013 Census Data District Health Board tables (Statistics New Zealand, n.d.). While not statistically significant, the ethnicity demographics had the most variance. This could have been due to the low response rate from the Southland maternity unit, as Invercargill has the highest concentration of resident Maori at 13.7\% (Statistics New Zealand, 2014b) within the Southern District Health Board. 
Table 15: Demographic comparison of survey data and SDHB 2013 maternity data

\begin{tabular}{|c|c|c|c|c|}
\hline & & $\begin{array}{c}2013 \\
(n=3478)\end{array}$ & $\begin{array}{l}\text { Survey } \\
(n=165)\end{array}$ & $\begin{array}{c}\text { Pearson's Chi } \\
\text { Squared* }\end{array}$ \\
\hline \multirow[t]{6}{*}{ Ethnicity } & European & $68 \%$ & $87 \%$ & \multirow{6}{*}{$p=0.224$} \\
\hline & Maori & $20 \%$ & $4 \%$ & \\
\hline & Pacific & $4 \%$ & $2 \%$ & \\
\hline & Asian & $6 \%$ & $6 \%$ & \\
\hline & Other & $2 \%$ & $1 \%$ & \\
\hline & Not Stated & $0 \%$ & $0 \%$ & \\
\hline \multirow[t]{3}{*}{ Age } & $<24$ & $21 \%$ & $13 \%$ & \multirow[t]{3}{*}{$p=0.223$} \\
\hline & $24-34$ & $58 \%$ & $60 \%$ & \\
\hline & $>34$ & $21 \%$ & $26 \%$ & \\
\hline \multirow[t]{11}{*}{ Facility } & Dunedin & $49 \%$ & $53 \%$ & \multirow[t]{11}{*}{$p=0.236$} \\
\hline & Invercargill & $36 \%$ & $24 \%$ & \\
\hline & Lakes & $1 \%$ & $5 \%$ & \\
\hline & Lumsden & $1 \%$ & $2 \%$ & \\
\hline & Winton & $1 \%$ & $4 \%$ & \\
\hline & Tuatapere & $1 \%$ & $1 \%$ & \\
\hline & Alexandra & $2 \%$ & $4 \%$ & \\
\hline & Oamaru & $3 \%$ & $1 \%$ & \\
\hline & Balclutha & $1 \%$ & $2 \%$ & \\
\hline & Gore & $3 \%$ & $2 \%$ & \\
\hline & Home & $3 \%$ & $2 \%$ & \\
\hline \multirow[t]{4}{*}{ Parity } & 1 & $41 \%$ & $48 \%$ & \multirow[t]{4}{*}{$p=0.213$} \\
\hline & 2 & $35 \%$ & $36 \%$ & \\
\hline & 3 & $16 \%$ & $11 \%$ & \\
\hline & $4+$ & $8 \%$ & $5 \%$ & \\
\hline \multirow[t]{8}{*}{ Income(\$) } & 0 & $5 \%$ & $1 \%$ & \multirow[t]{8}{*}{$p=0.243$} \\
\hline & $0-10,000$ & $11 \%$ & $2 \%$ & \\
\hline & $10,000-30,000$ & $28 \%$ & $6 \%$ & \\
\hline & $30,000-50,000$ & $19 \%$ & $13 \%$ & \\
\hline & $50,000-70,000$ & $11 \%$ & $13 \%$ & \\
\hline & $70,000-100,000$ & $16 \%$ & $31 \%$ & \\
\hline & $100,000+$ & $3 \%$ & $26 \%$ & \\
\hline & Do not want to state & $8 \%$ & $7 \%$ & \\
\hline \multirow[t]{6}{*}{ Education } & No secondary & $7 \%$ & 21 & \multirow[t]{6}{*}{$p=0.242$} \\
\hline & Secondary & $15 \%$ & 37 & \\
\hline & Nat cert/Diploma & $28 \%$ & 18 & \\
\hline & Undergrad & $30 \%$ & 10 & \\
\hline & PostGraduate & $20 \%$ & 14 & \\
\hline & Other & $0 \%$ & 10 & \\
\hline
\end{tabular}

*Calculated from actual numbers not $\%$ 


\section{Responses to core questions}

The core questions were not compulsory and were answered in the following ways. Q4a (close to home), Q4b (close to family) and Q4f (safety) were the most frequently answered. Q4a and Q4f had the largest mean except for the thirteen people who stated another reason for their choices. The data was not normally distributed, as is often a feature of visual analogue scales.

Table 16: Descriptive statistics of the core survey questions

\begin{tabular}{|l|r|r|r|r|r|}
\hline \multicolumn{6}{|c|}{ Descriptive Statistics - Core Questions (Q4a-g) } \\
\hline & \multicolumn{1}{|c|}{ N } & Minimum & Maximum & Mean (SD) & Median \\
\hline (a) Close to home & 130 & 2 & 100 & $81(23)$ & 88 \\
(b) Close to Family & 129 & 1 & 100 & $63(34)$ & 78 \\
(c) No other options & 115 & 1 & 100 & $46(35)$ & 35 \\
(d) Services Offered & 129 & 1 & 100 & $67(30)$ & 80 \\
(e) Recommended place & 123 & 1 & 100 & $66(28)$ & 70 \\
(f) Where I felt safe & 128 & 1 & 100 & $80(22)$ & 85 \\
(g) Other & 13 & 1 & 100 & $85(26)$ & 93 \\
\hline
\end{tabular}

\section{Demographics - Core Questions}

Initially each demographic group was individually tested using KruskalWallis (a non-parametric test due to the skewness of the question response data); there was no statistical significance shown in how the core questions were answered. Testing using a one-way ANOVA method and Kruskal-Wallis showed very little difference in results, indicating the skew was not a major issue; however, due to known skew it was felt better to continue with non-parametric testing.

Linear regression was not run, as no variable showed statistical significance. 
Table 17: Statistical significance of demographics variables for each survey question (Kruskal-Wallis test)

\begin{tabular}{|l|r|r|r|r|r|r|}
\cline { 2 - 7 } \multicolumn{1}{c|}{} & $\begin{array}{l}\text { Q4a - } \\
\text { Close to } \\
\text { Home }\end{array}$ & $\begin{array}{l}\text { Q4b - } \\
\text { Close to } \\
\text { Family }\end{array}$ & $\begin{array}{l}\text { Q4c - No } \\
\text { other } \\
\text { options }\end{array}$ & $\begin{array}{l}\text { Q4d - } \\
\text { Services } \\
\text { offered }\end{array}$ & $\begin{array}{l}\text { Q4e - } \\
\text { recommended } \\
\text { place }\end{array}$ & $\begin{array}{l}\text { Q4f - } \\
\text { Where I } \\
\text { feel safe }\end{array}$ \\
\hline Parity & 0.812 & 0.368 & 0.793 & 0.238 & 0.962 & 0.741 \\
\hline Distance & 0.294 & 0.186 & 0.859 & 0.277 & 0.182 & 0.467 \\
\hline Age & 0.905 & 0.490 & 0.715 & 0.200 & 0.436 & 0.322 \\
\hline Ethnicity & 0.859 & 0.102 & 0.228 & 0.591 & 0.274 & 0.317 \\
\hline Education & 0.654 & 0.254 & 0.477 & 0.294 & 0.858 & 0.148 \\
\hline Income & 0.512 & 0.141 & 0.228 & 0.591 & 0.865 & 0.976 \\
\hline
\end{tabular}

*Asympotitic significances shown (significance level is .05)

Although this table shows nothing statistically significant, the highlighted variables for $\mathrm{Q} 4 \mathrm{~b}$ (the importance of being close to family) showed stronger significance for ethnicity and income.

Other research found some demographic differences in response between those women selecting a primary unit and those selecting a complex care unit to birth in (C. Grigg et al., 2014). However, in this small sample, little difference was detected and the only finding of statistical significance was a variation in ethnicity $(p=.026)$.

Table 18: Demographic distribution between differing birthplace (complex, primary \& home)

\begin{tabular}{|l|r|}
\hline & Significance \\
\hline Parity & .148 \\
\hline Age Range & .742 \\
\hline Ethnicity & .026 \\
\hline Income & .570 \\
\hline Education & .378 \\
\hline
\end{tabular}

This ethnicity factor was suggested in New Zealand literature relating to birth choice, namely in Davis et al's study where they found that Māori women were more liked to birth in a primary setting $(2011$, p. 5). This was also found to be true in the 
survey group ( $p=0.13$ ); however, results should be treated with caution due to the very small sample $(n=7)$.

Table 19: \% of European and Māori women at each type of birthplace

\begin{tabular}{|l|r|r|}
\hline \multicolumn{1}{|c|}{ Chosen Birth Place } & New Zealand European (\%) & \multicolumn{1}{c|}{ Māori (\%) } \\
\hline Complex Care Setting & $78(64.4)$ & $4(57.2)$ \\
\hline Primary Setting & $4(32.3)$ & $1(28.5)$ \\
\hline Home & $39(3.3)$ & $2(14.3)$ \\
\hline
\end{tabular}

No other demographic factor was statistically significant in selected birth place.

\section{Other reasons - Question 4g - "Other"}

The answers to Q4g stating 'other' reasons were the only free-text part of the survey, and produced interesting comments. Some stated they chose their hospital because they needed specialist care. This was in fact Question 3 "Did you choose this location because you required specialist obstetric care due to complications or risk factors?" and women were asked to skip the rating question completely if these perceived clinical requirements negated some of their free choice of birth place. 34 women selected this but some went on to complete the questionnaire fully and gave reasons such as twins or induction as a reason for their birth place choice.

Some other reasons given have been grouped into actual birth place below:

\section{Complex Care Facility}

- "In case of emergency e.g. not have to travel 2 hours"

- "Fear of complications with first pregnancy in a primary care facility"

- "Only main hospital in area" 


\section{Primary Unit}

- "Partner able to stay at nights"

- "Avoid Travel"

- "A place where my baby, husband and I could sleep together"

\section{$\underline{\text { Homebirth }}$}

- "Environment of the home"

- "Economics - homebirth"

- "Could not guarantee birth pool in hospital"

\section{Lack of choice - Question 4c - "no other options"}

Question 4c concerned lack of birth place choice "no other options in my area". This was answered less frequently and had the lowest mean of $46.41 \%$. While the mean response was slightly higher in the Invercargill and Dunedin complex care groups, there was variance across all birth places that could not be attributed to a choice of primary/complex or home. The homebirth group were least likely to state this as a factor $($ mean $=17.83 \%)$.

\section{Tension of Distance}

Even though safety and proximity to home and family were the main factors influencing choice of birthplace, it appears that decision tension arose when the birth place women considered 'safe' was distant from their home. In these cases, the need for safety seemed to take priority (Figure 21). 
Figure 21: Means of Home and safety priority questions vs distance travelled to birth place

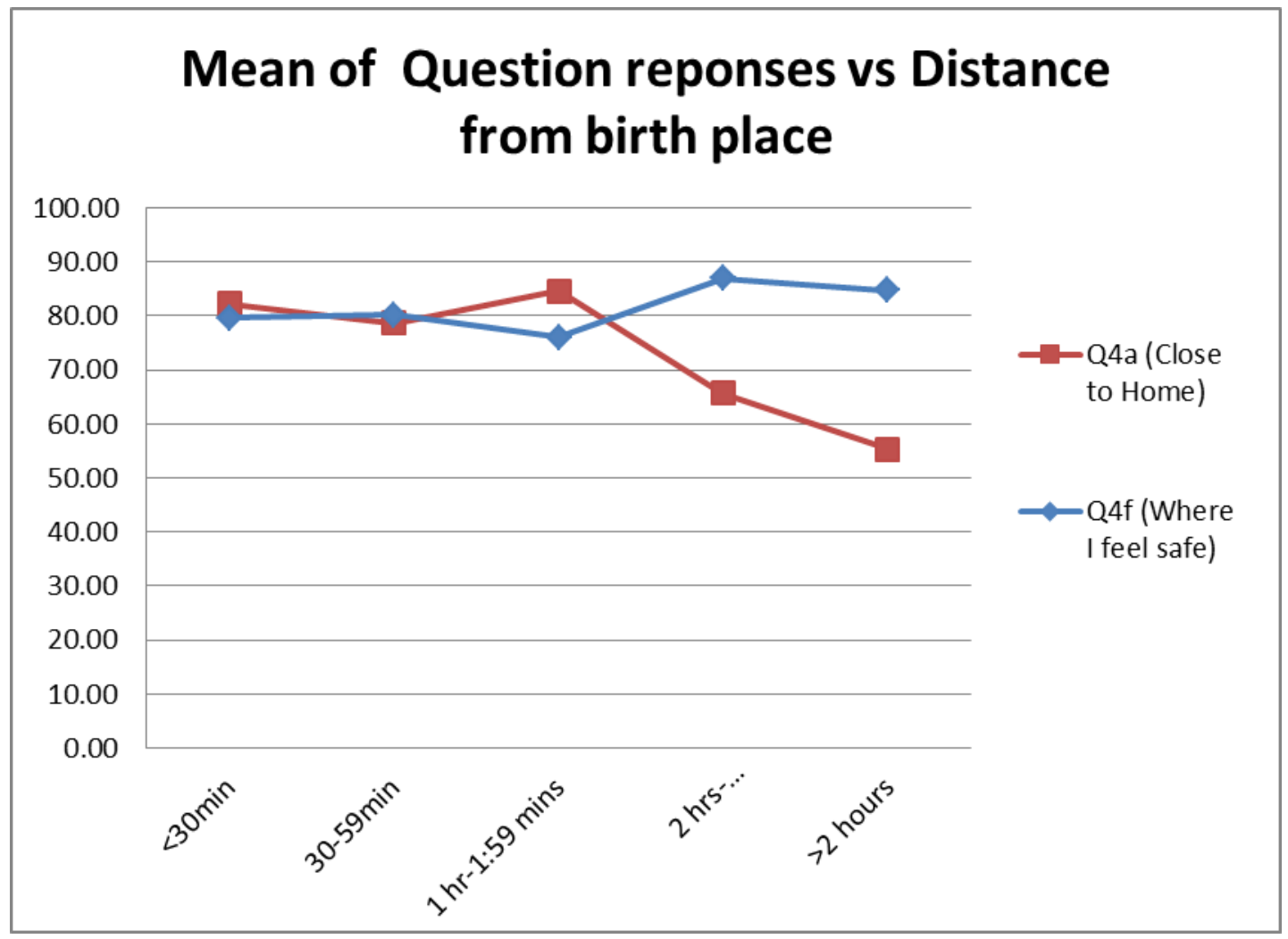

The significance did not change much over distance for Question Q4f (Where I feel safe) but did for Q4a (Close to home) as shown in Table 20 below. The importance of being close to home was less at greater distances.

Table 20: Significance of change in distribution of question response across distance categories

\begin{tabular}{|l|r|}
\hline Question & Significance \\
\hline Q4a - Close to Home & 0.163 \\
\hline Q4f - Where I feel Safe & 0.906 \\
\hline
\end{tabular}




\section{Chapter 5 - Discussion}

\section{Spatial Data}

This research showed that the birthing women of the Southern District Health Board in 2013 were mainly choosing not to birth at their closest maternity unit unless they lived in a large urban area with a single complex care facility. Primary facilities and homebirth appeared much less attractive even when units were located in close proximity, as in most rural areas. At best, it appears that women were three times more likely to select a complex unit, but in some areas they were ten times more likely to travel out of their home region. With a normal birth rate in 2011 of $65 \%$ (Ministry of Health, 2014c), this seems incongruent.

The analysis of travel data identified that the women in the southern part of the District Health Board were well served for maternity facilities. In the northern reaches, i.e. Wanaka, Hawea and into Omarama, services were sparse. The women in the north had much longer distances to travel if they needed or chose to attend complex care facilities, and this was also identified as an area of particular population growth.

While rural women had birth place options of local primary units or travelling to the larger complex services, urban women did not. There are eight rural primary maternity units in the District Health Board, but no stand-alone primary facilities in the two main urban centres. Secondary and tertiary hospitals are funded to provide primary services within their facilities; these are delivered in a different context, as discussed in the literature review section and elaborated on in van Teijlingen \& Pitchforth (2010). Miller \& Skinner also point out that carers even behave differently in these units (2012) in comparison to primary units or at home. 
The maternity units at both Dunedin and Southland Hospitals are single birthing suites and do not have any separate primary midwifery-led area; as a result, both complex and primary care happens in the same physical space. Normal birth does occur within these units and statistics from Queen Mary Maternity Centre, the tertiary facility in Dunedin, showed a normal birth rate of 53.8\% for 2013 (Southern District Health Board, 2014).

Birth place choice did correlate somewhat with Reilly's basic point-to-point gravity model - where the attractiveness (or gravity) of one maternity facility against another was calculated factoring in birth numbers and distance. This could explain why women are reluctant to travel away from a complex unit to attend a primary facility; this only occurred in a few cases in the 2013 cohort, all of which were where the primary facility was very close to a complex care one. It appears that to the women of the Southern District Health Board in 2013, complex units are much more attractive birthing locations than primary ones.

Huff predictive spatial modelling did not concur with women's actual travel patterns; this could indicate that geographical factors had only a small influence on birthplace choice as more personal parameters where not used in the model. The model could be refined for individual women, based on the survey outcomes providing some predictive parameters, such as an individual perception of safety. The Huff model has been used extensively in health service provision but the results here raise the question of whether the choices made around birthplace are congruent with the decisions around accessing general healthcare services. Caution should be taken when applying a universal health service model to maternity. This would require further research comparing utilisation of a variety of health services. 
With women choosing complex services over primary and the lack of services in the northern central region, the impact of new services in that area were hypothesised. A primary care unit in Wanaka probably would have a potential of more than 100 births a year. There is the possibility that women in the Omarama area (currently over 120 minutes from any facility) may utilize the hypothetical Wanaka unit so another 15-10 births could be achieved there. Even with an increased rate of population growth, the 2013 birth travel patterns do bring into question whether such a unit would be well utilized.

While the Cromwell area is already serviced by primary units at Lakes Hospital in Queenstown and Charlotte Jean Maternity in Alexandra, location/allocation modelling based on the 2013 demand points (birthing women's residential addresses) shows that Cromwell would be a good choice for a secondary service. The Cromwell location has also been speculated on to meet the increasing broader healthcare needs of the region.

\section{Data Limitations}

One limitation of the 2013 birth data used for spatial analysis is that there was no relationship with birth interventions and outcomes. This meant that it was impossible to tell which women needed to be at complex care units for clinical reasons; this could only be hypothesised based on the $201165 \%$ normal birth rate. It would be interesting for future research to look at interventions and clinical needs of the women making these travel decisions as another layer of analysis.

\section{Survey}

The survey sample was disappointingly small, even though great care was taken to encourage response rates. Although representative, due to the low power of 
the sample findings from the survey cannot safely be generalized to the larger population. They are congruent with other research in that a perception of safety was a prime consideration in choosing birthplace (Barber et al., 2006; Davis et al., 2011; C. Grigg et al., 2014; Houghton et al., 2008; Lavender \& Chapple, 2005).

The primacy of safety was the same for all demographic groups as well as across the selected birthplaces of complex care, primary care and home. The need to be close to home and family was also very important to women; however, for those living a long distance from their chosen birth place, the need to feel safe took precedence over remaining close to home (Figure 22). While there were few respondents who cited other reasons for their birthplace choice, the theme of distance from care in an emergency was reflected in those women selecting complex care; this was congruent with themes in Patterson's study of rural New Zealand maternity transfers (2009) and also in Howie's small study (2007). Again, these responses echoed the women's need to feel safe in question 4(f) of the survey.

It is of note that recommendation of birthplace by midwives or doctors was not a strong feature in the responses, indicating that women are making birthplace choices around other factors. The influence of carer was a frequent theme in the UK birthplace choice studies. It could be that this difference is due to the partnership model of the New Zealand maternity system; however this would require further research to determine.

\section{Survey Limitations}

There were issues with the survey section of this data around design of the questions and the implementation of the survey. Although checked before release, when it came to analysis, "Rank as many or as few as you want" was not the best 
wording of the introduction to the core questions (Q4a-g). The assumption cannot be made that simply because a women did not answer a question indicates it was not important to her. In the analysis, if a core question was not answered it was considered missing data rather than a $0 \%$ or not important.

Although all maternity units had enthusiastically supported the study when presented to them, and a locality approval gained from the Southern District Health Board, implementation, distribution and collection of the survey did not go smoothly. It was ambitious to survey so many sites and changing staff, rostered employees and lack of support in some locations meant survey distribution was uneven. This is reflected in the response rates. At the larger units, surveys were also only issued once a day; this missed any women who went home straight from delivery suite or left within 24 hours of birth. For example, in Dunedin, 104 women went home within 24 hours of giving birth over the three month study period.

It was also discovered by some lead maternity carer midwives that women had taken their survey form home with them on discharge rather than handing it in as they left. Some LMCs did return the questionnaires to the units, but it is difficult to know how many never came back. In hindsight a postal survey at 6 weeks postpartum or a survey in the ante natal period may have been more effective. An online survey could also have been used as a more cost effective tool; however this has had limited success in other maternity studies in the Dunedin maternity context. 


\section{Chapter 6-Conclusions}

This study showed that many women in the Southern District Health Board in 2013 were not utilizing their nearest maternity facility if it was a primary one. Rural women were travelling long distances to access complex care maternity services and these journeys were not in line with the $201165 \%$ normal birth rate.

Spatial modelling could not explain these travel patterns, indicating that while gravity or attractiveness of the complex facilities was a factor, distance and other geographic factors were not the primary influences in birth place choice. It could be that psychological distance is a cause, where perceived impediments or incentives to access influence decision making, based around complex social and economic elements (Longley et al., 2011). It also appeared that the area was well serviced in maternity facilities. Only in the north of the Southern District Health Board, in the Central Otago regions where there is rapid population growth, could services be better configured to given women more choice and reduce birth travel distances.

The survey of 165 women in a three month period of 2014 also revealed thematic patterns about women's choices and inclinations in a variety of birth settings and distances travelled to fulfil their birth place preferences. Safety was the primary concern in birthplace choice, with a desire to be close to home and family very close behind. For rural women, the need to be close to home was further behind the need for safety than women in the main centres, but the urban women had little choice in birth locations. These results were congruent with other recent New Zealand research on birth place choice and also reflected themes previously 
uncovered in research about rural women's choice of birth place (C. Grigg et al., 2014; Howie, 2007; Patterson, 2009).

A feeling of safety assists with the physiological birth process. Literature around undisturbed birth notes the rise in cortisol which inhibits labour when women are stressed and don't feel safe (Buckely, 2008; Kirkham \& Jowitt, 2012). This leads to the saying "Women birth best where they feel safe". The findings of this research imply that women choose their birth place with a primary focus on safety, whether it be a complex care unit, a rural primary unit, or home. Therefore, these women's perception of safety must have a differing underlying construct. The women who can only feel safe at home and those who feel they need to be in a complex unit must perceive 'safety' in different ways.

The findings of this study could be viewed in several ways. A majority of women are choosing to birth in a complex care unit and making long journeys to do this. Knowing that a feeling of safety is highly important to women could be used to empower low-risk women to feel safer birthing in primary settings. Recent research on birth outcomes has indicated that primary birth is just as safe as a complex setting for this group of women, if not safer (National Institute for Health and Clinical Excellence, 2014). On the other hand, it could be used to promote larger complex care facilities as the only safe place for birth, and so influence women's choice if centralisation of maternity care was a health service priority. In light of this, care should be taken by maternity care providers when discussing safety and birthplace with women.

While patterns could be analysed and modelled spatially, and some geographic influences examined by GIS tools, the deeper reasons behind birth place 
choice could not be quantified in the same way. While the project started with an attempt to "codify the miracle of existence", it seems that women's choices cannot put down on any map.

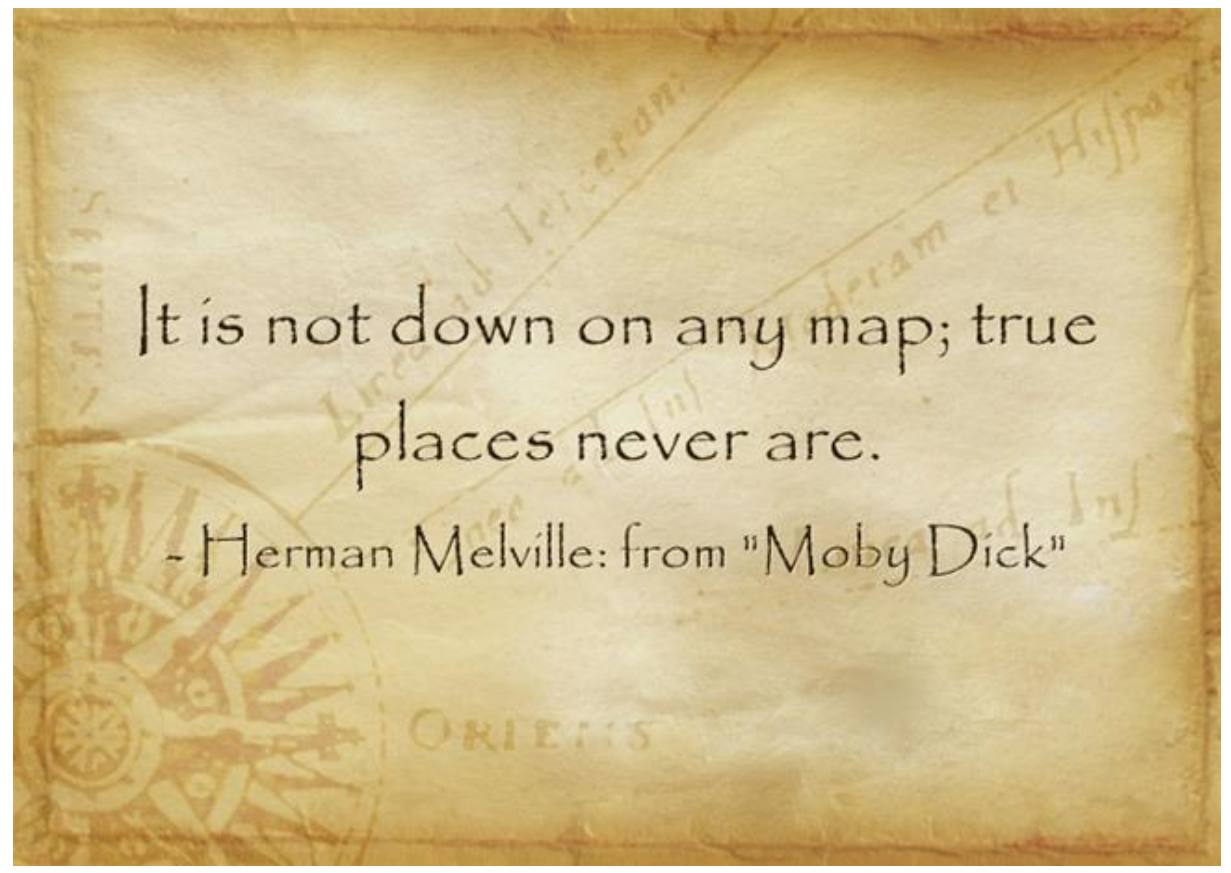




\section{References}

Abel, S., \& Kearns, R. A. (1991). Birth places: A geographical perspective on planned home birth in New Zealand. Social Science \& Medicine, 33(7), 825834. doi:10.1016/0277-9536(91)90387-R

Alwin, D. F., \& Krosnick, J. A. (1985). The Measurement of Values in Surveys: A Comparison of Ratings and Rankings. Public Opinion Quarterly, 49(4), 535. doi:10.1086/268949

Arcury, T. A., Gesler, W. M., Preisser, J. S., Sherman, J., Spencer, J., \& Perin, J. (2005). The effects of geography and spatial behavior on health care utilization among the residents of a rural region. Health Services Research, 40(1), 135-55. doi:10.1111/j.1475-6773.2005.00346.x

Atkinson, J., Salmond, C., \& Crampton, C. (2014). NZDep2013 Index of Deprivation. Retrieved from http://www.otago.ac.nz/wellington/otago069936.pdf

Augé, M. (2008). Non-Places (2nd ed.). Verso.

Bagheri, N., Benwell, G. L., \& Holt, A. (2005). Measuring spatial accessibility to primary health care. In 17th Annual Colloquium of the Spatial Information Research Centre (SIRC 2005: A Spatio-temporal Workshop). (pp. 103-108). Dunedin: University of Otago.

Banks, M. (2000). Home Birth Bound: Mending the Broken Weave. Hamilton: Birthspirit Books Ltd.

Barber, T., Rogers, J., \& Marsh, S. (2006). The Birth Place Choices Project: Phase One. British Journal of Midwifery, 14(10), 609-613. Retrieved from http://ovidsp.ovid.com/athens/ovidweb.cgi?T=JS\&NEWS=N\&PAGE=fulltext $\& \mathrm{AN}=2006110930 \& \mathrm{D}=$ mwic

Bashford, A., \& Tracy, S. W. (2012). Introduction: modern airs, waters, and places. Bulletin of the History of Medicine, 86(4), 495-514. doi:10.1353/bhm.2012.0084

Bashour, H., \& Abdulsalam, A. (2005). Syrian women's preferences for birth attendant and birth place. Birth (Berkeley, Calif.), 32, 20-26. doi:BIR333 [pii] $\backslash \mathrm{r} 10.1111 / \mathrm{j} .0730-7659.2005 .00333 . x$ [doi]

Bedwell, C., Houghton, G., Richens, Y., \& Lavender, T. (2011). "She can choose, as long as I'm happy with it': a qualitative study of expectant fathers' views of birth place. Sexual \& Reproductive Healthcare: Official Journal of the Swedish Association of Midwives, 2(2), 71-5. doi:10.1016/j.srhc.2010.12.001 
Beere, P., \& Brabyn, L. (2006). Providing the evidence: Geographic accessibility of maternity units in New Zealand. New Zealand Geographer, 62(2), 135-143. doi:10.1111/j.1745-7939.2006.00056.x

Boucher, D., Bennett, C., McFarlin, B., \& Freeze, R. (2009). Staying Home to Give Birth: Why Women in the United States Choose Home Birth. Journal of Midwifery and Women's Health, 54(2), 119-126.

Bowden, A. (2002). Methods for pre-testing and piloting survey questions: illustrations from the KENQOL survey of health-related quality of life. Health Policy and Planning, 17(3), 322-330. doi:10.1093/heapol/17.3.322

Brabyn, L., \& Skelly, C. (2002). Modeling population access to New Zealand public hospitals. International Journal of Health Geographics, 1(1), 3. doi:10.1186/1476-072X-1-3

Brocklehurst, P., Hardy, P. (Pollyanna), Hollowell, J. (Jennifer), Linsell, L. (Louise), Macfarlane, A. (Alison), McCourt, Christine, 1960-, ... Stewart, M. (Mary). (2011). Perinatal and maternal outcomes by planned place of birth for healthy women with low risk pregnancies: the Birthplace in England national prospective cohort study. BMJ (Clinical Research Ed.), 343(nov23_4), d7400. doi:10.1136/bmj.d7400

Brown, B. A., Long, H. L., Gould, H., Weitz, T., \& Milliken, N. (2004). A conceptual model for the recruitment of diverse women into research studies. Journal of Women's Health \& Gender-Based Medicine, 9(6), 625-32. doi:10.1089/15246090050118152

Brown, T., McLafferty, S. L., \& Moon, G. (2010). A Companion to Health and Medical Geography. (T. Brown, S. L. McLafferty, \& G. Moon, Eds.). Chichester: Blackwell Publishing Ltd. Retrieved from http://onlinelibrary.wiley.com/book/10.1002/9781444314762

Brownstein, J. S., Cassa, C. A., \& Mandl, K. D. (2006, October 19). No Place to Hide - Reverse Identification of Patients from Published Maps - NEJM. doi:10.1056/NEJMc061891

Buckely, S. J. (2008). Unlocking The Potential For Normality. In S. Wickham (Ed.), Midwifery :Best Practice Volume 5 (p. 163). Elsevier Health Sciences.

Cassa, C. A., Wieland, S. C., \& Mandl, K. D. (2008). Re-identification of home addresses from spatial locations anonymized by Gaussian skew. International Journal of Health Geographics, 7, 45. doi:10.1186/1476-072X-7-45

Cheyney, M. J. (2008). Homebirth as systems-challenging praxis: knowledge, power, and intimacy in the birthplace. Qualitative Health Research, 18(2), 254267. doi:10.1177/1049732307312393 
Clarke, A. (2012). Born to a Changing World: Childbirth in Nineteenth-Century New Zealand. Bridget Williams Books. Retrieved from http://books.google.com/books?id=ZP11vnfeGiIC\&pgis=1

Combier, E., Zeitlin, J., de Courcel, N., Vasseur, S., Lalouf, A., Amat-Roze, J. M., \& de Pouvourville, G. (2004). Choosing where to deliver: decision criteria among women with low-risk pregnancies in France. Social Science \& Medicine (1982), 58(11), 2279-89. doi:10.1016/j.socscimed.2003.08.015

Congdon, P. (2000). A Bayesian Approach to Prediction Using the Gravity Model, with an Application to Patient Flow Modeling. Geographical Analysis, 32(3), 205-224. doi:10.1111/j.1538-4632.2000.tb00425.x

Conrad, P. (2008). The Medicalization of Society: On the Transformation of Human Conditions into Treatable Disorders. JHU Press. Retrieved from http://books.google.co.nz/books/about/The_Medicalization_of_Society.html?id $=\mathrm{cAE} 5 \mathrm{hlP} 5 \mathrm{YkAC} \&$ pgis $=1$

Coxon, K. (2012). Birth Place Decisions: a prospective, qualitative study of how women and their partners make sense of risk and safety when choosing where to give birth. King's College London (University of London). Retrieved from http://ethos.bl.uk/OrderDetails.do?uin=uk.bl.ethos.587062

Coxon, K., Sandall, J., \& Fulop, N. J. (2014). To what extent are women free to choose where to give birth? How discourses of risk, blame and responsibility influence birth place decisions. Health, Risk \& Society, 16(1), 51-67. doi:10.1080/13698575.2013.859231

Cromley, E. K., \& McLafferty, S. L. (2002). GIS and Public Health. New York: The Guilford Press.

Davis, D., Baddock, S., Pairman, S., Hunter, M., Benn, C., Wilson, D., ... Anderson, J. (2011). Do low risk women actually birth in their planned place of birth and does ethnicity influence women's choices of birthplace? New Zealand College of Midwives, 44(2), 5-10. doi:10.1111/j.1523-536X.2010.00458.x

Dawson, P. (2013). Where do women travel to give birth within New Zealand? In A. Moore \& P. A. Whigham (Eds.), Proceedings of the SIRC NZ - GIS and Remote Sensing Research Conference. Dunedin: Otago University.

Delamater, P. L., Messina, J. P., Shortridge, A. M., \& Grady, S. C. (2012). Measuring geographic access to health care: raster and network-based methods. International Journal of Health Geographics, 11(1), 15. doi:10.1186/1476072X-11-15

Department of Health. (1993). Changing Childbirth, Part 2. H.M. Stationery Office.

Department of Health. (2007, August 2). Maternity matters : choice, access and continuity of care in a safe service. Department of Health. Retrieved from http://dera.ioe.ac.uk/9429/1/dh_074199.pdf 
Dixon, L., Prileszky, G., Guilliland, K., Miller, S., \& Anderson, J. (2014). Place of birth and outcomes for a cohort of low risk women in New Zealand: A comparison with Birthplace England. New Zealand College of Midwives Journal, 50(December), 11-18.

Drezner, T. (1994). Locating a single new facility among existing, unequally attractive facilities. Journal of Regional Science, 34(2), 237-252. doi:10.1111/j.1467-9787.1994.tb00865.x

Duckham, M., \& Kulik, L. (2005). A Formal Model of Obfuscation and Negotiation for Location Privacy. In H.-W. Gellersen, R. Want, \& A. Schmidt (Eds.), Pervasive Computing SE - 10 (Vol. 3468, pp. 152-170). Springer Berlin Heidelberg. doi:10.1007/11428572_10

Duckham, M., \& Kulik, L. (2006). Location privacy and location-aware computing. In R. Billen, E. Joao, \& D. Forrest (Eds.), Dynamic and Mobile GIS: Investigating Changes in Space and TIme (pp. 35-51). Boca Raton: CRC Press.

Durie, M. (2001). Mauri Ora: The Dynamics of Māori Health. Oxford University Press Australia \& New Zealand. Retrieved from http://books.google.co.nz/books/about/Mauri_Ora.html?id=wxR9QgAACAAJ \&pgis $=1$

Dyck, I., \& Kearns, R. (1995). Transforming the relations of research: towards culturally safe geographies of health and healing. Health \& Place, 1(3), 137147. doi:10.1016/1353-8292(95)00020-M

Ellis, R. (1998). He Rato Tapuhi: Maternity Services for Māori Women. Waikato Print. Retrieved from http://books.google.co.nz/books/about/He_Rato_Tapuhi.html?id=UlejtgAACA AJ\&pgis $=1$

ESRI. (2013). ArcGIS 10.2 for Desktop. Redlands: ESRI.

ESRI. (2014). ArcGIS - ArcGIS Online Network Dataset Coverage. Retrieved November 5, 2014, from http://www.arcgis.com/home/item.html?id=b7a893e8e1e04311bd925ea25cb8d $7 \mathrm{c} 7$

Fahy, K., Foureur, M., \& Hastie, C. (Eds.). (2008). Birth Territory and Midwifery Guardianship. Edinburgh: Elsevier. Retrieved from https://www.elsevier.com/books/birth-territory-and-midwiferyguardianship/fahy/978-0-7506-8870-3

Flater, D. (2010). Market Analysis with the Huff Model - Generic Script Tool. 2010. Retrieved from http://arcscripts.esri.com/details.asp?dbid=15999

Foucault, M. (1994). The Birth of the Clinic. New York: Vintage Books. 
Fox, R. T., \& Fox, D. H. (1974). The Use of Central Place Theory for the Location of Maternal and Infant Care Projects. American Journal of Public Health, 64(9), 898-903.

Retrieved

from http://ezproxy.massey.ac.nz/login?url=http://search.ebscohost.com/login.aspx?d irect $=$ true $\& \mathrm{db}=$ ehh $\& A N=7971334 \&$ site $=$ eds-live

Galvão, R. D., Nobre, F. F., \& Vasconcellos, M. M. (1999). Mathematical location models applied in the spatial organization of health units. Revista de Saúde Pública, 33(4), 422-34. Retrieved from http://www.ncbi.nlm.nih.gov/pubmed/10542477

Gärling, T., Selart, M., \& Böök, A. (2013). Investigating Spatial Choice and Navigation in Large-scale Environments. In N. Foreman \& R. Gillett (Eds.), Handbook Of Spatial Research Paradigms And Methodologies (2nd ed., pp. 153-164). Hoboken: Taylor and Francis. Retrieved from http://reader.eblib.com.au.wmezproxy.wnmeds.ac.nz/(S(zqxtxxjpywt2k3dqkewj jqzw)) $/$ Reader.aspx? $\mathrm{p}=1111761 \& \mathrm{o}=83 \& \mathrm{u}=$ Yug7prCWxnjtzfvft4\%2fI8g\%3d $\%$ 3d\&t=1416105178\&h=A518A690FB79DF2679B3F2B7B028339EE82D3D7B $\& s=16452311 \& u t=198 \& p g=1 \& r=i m g \& c=-1 \& p a t=n \& c m s=-1 \& s d=1 \#$

Giacaman, R., Abu-Rmeileh, N. M. E., \& Wick, L. (2007). The limitations on choice: Palestinian women's childbirth location, dissatisfaction with the place of birth and determinants. European Journal of Public Health, 17(1), 86-91. doi:10.1093/eurpub/ck1089

Gilhuus Trandum, M., \& Steen, J. (2012). Traditional and professional birth attendants influence on womens decisions of birth place and type of birth assistance - A qualitative study in Tanga District, Tanzania [Norwegian]. Nordic Nursing Research Nordisk Sygeplejeforskning, 2(1), 87-92. Retrieved from

http://rlib.pace.edu/login?url=http://search.ebscohost.com/login.aspx?direct=tru $\mathrm{e} \& \mathrm{db}=\operatorname{cin} 20 \& \mathrm{AN}=2011596549 \&$ site $=$ ehost-live $\&$ scope $=$ site

Gjesfjeld, C. D., \& Jung, J.-K. (2011). How far?: Using geographical information systems (GIS) to examine maternity care access for expectant mothers in a rural state. Social Work in Health Care, 50(9), 682-93. doi:10.1080/00981389.2011.575537

Golledge, R. D., \& Stimpson, R. J. (1996). Spatial Behavior: A Geographic Perspective. New York: Guilford Press. Retrieved from http://www.amazon.com/Spatial-Behavior-A-GeographicPerspective/dp/1572300507

Golledge, R., \& Timmermans, H. (1988). Behavioural Modelling in Geography and Planning. Beckenham: Croom Helm Ltd. Retrieved from http://www.amazon.com/Behavioural-Modelling-Geography-PlanningReginald/dp/0709938535 
Gregory, D., Johnston, R., Pratt, G., Watts, M. J., \& Whatmore, S. (2009). The Dictionary of Human Geography. (R. J. Johnston, D. Gregory, \& D. M. Smith, Eds.) (5th ed.). Chichester: Wiley-Blackwell.

Grigg, C. P., \& Tracy, S. K. (2013). New Zealand's unique maternity system. Women and Birth: Journal of the Australian College of Midwives, 26(1), e5964. doi:10.1016/j.wombi.2012.09.006

Grigg, C., Tracy, S. K., Daellenbach, R., Kensington, M., \& Schmied, V. (2014). An exploration of influences on women's birthplace decision-making in New Zealand: a mixed methods prospective cohort within the Evaluating Maternity Units study. BMC Pregnancy and Childbirth, 14(1), 210. doi:10.1186/14712393-14-210

Grzybowski, S., Kornelsen, J., \& Schuurman, N. (2009). Planning the optimal level of local maternity service for small rural communities: a systems study in British Columbia. Health Policy (Amsterdam, Netherlands), 92(2-3), 149-57. doi:10.1016/j.healthpol.2009.03.007

Grzybowski, S., Stoll, K., \& Kornelsen, J. (2011). Distance matters: a population based study examining access to maternity services for rural women. BMC Health Services Research, 11, 147. doi:10.1186/1472-6963-11-147

Guagliardo, M. F. (2004). Spatial accessibility of primary care: concepts, methods and challenges. International Journal of Health Geographics, 3(1), 3. doi:10.1186/1476-072X-3-3

Guilliland, K., \& Pairman, S. (2012). Women's business: the story of the New Zealand College of Midwives 1986-2010 - Dunedin Campus. Christchurch: New Zealand College of Midwives.

Hadjigeorgiou, E., Kouta, C., Papastavrou, E., Papadopoulos, I., \& Mårtenson, L. B. (2012). Women's Perceptions of Their Right to Choose the Place of Childbirth: A Qualitative Study. International Journal of Childbirth, 2(4), 230-240. doi:10.1891/2156-5287.2.4.230

Hadjigeorgiou, E., Kouta, C., Papastavrou, E., Papadopoulos, I., \& Mårtensson, L. B. (2012). Women's perceptions of their right to choose the place of childbirth: an integrative review. Midwifery, 28(3), 380-90. doi:10.1016/j.midw.2011.05.006

Haynes, K. E., \& Fotheringham, A. S. (1984). Gravity and Spatial Interaction Models. Beverley Hills: Sage.

Hazen, H., \& Anthamatten, P. (2011). An introduction to the geography of health. London: Routledge. Retrieved from http://www.routledge.com/cw/anthamatten/

Health Partners Consulting Group. (2014). Southern District Health Board Health Profile 2013. HPCG. Auckland. Retrieved from http://www.southerndhb.govt.nz/files/11700_2014032884154-1395949314.pdf 
Health Research Council of New Zealand. (2010). Guidelines for Researchers on Health Research Involving Māori (Version 2). Retrieved April 28, 2014, from http://www.hrc.govt.nz/news-and-publications/publications/guidelinesresearchers-health-research-involving- $\mathrm{m} \% \mathrm{C} 4 \% 81$ ori

Hendry, C. (2009). Report on mapping the rural midwifery workforce in New Zealand for 2008. New Zealand College of Midwives, 41(41), 12-19.

Hendry, C. (2009). The New Zealand Maternity System: A midwifery Renaissance. In R. Davis-Floyd, L. Barclay, B.-A. Daviss, \& J. Tritten (Eds.), Birth Models That Work (pp. 55-87). Berkley: University of California Press.

HERE. (2014). About HERE. Retrieved November 5, 2014, from http://here.com/abouthere/?lang=en-US

Hernández-Ávila, J. E., Santos-Luna, R., Palacio-Mejía, L. S., Salgado-Salgado, A. L., Ríos-Salgado, V. H., Rodríguez-López, M. H., \& Sepúlveda-Amor, J. (2010). Automated geospatial model for health services strategic planning. Salud Pública de México, 52(5), 432-46. Retrieved from http://www.ncbi.nlm.nih.gov/pubmed/21031250

Higgs, G. (2009). The role of GIS for health utilization studies: literature review. Health Services and Outcomes Research Methodology, 9(2), 84-99. doi:10.1007/s10742-009-0046-2

Hodgson, M. J. (1986). A hierarchical location-allocation model with allocations based on facility size. Annals of Operations Research, 6(8), 273-289. doi:10.1007/BF02023746

Hodgson, M. J. (1988). An hierarchical location-allocation model for primary health care delivery in a developing area. Social Science \& Medicine, 26(1), 153-161. doi:10.1016/0277-9536(88)90054-8

Hohmann, A. A., \& Parron, D. L. (1996). How the New NIH Guidelines on Inclusion of Women and Minorities Apply: Efficacy Trials, Effectiveness Trials, and Validity. Journal of Consulting and Clinical Psychology, 64(5), 851-855. doi:10.1037/0022-006X.64.5.851

Houghton, G., Bedwell, C., Forsey, M., Baker, L., \& Lavender, T. (2008). Factors influencing choice in birth place -- an exploration of the views of women, their partners and professionals. Evidence Based Midwifery, 6(2), 59-64.

Howie, J. (2007). Choosing the place of birth: how primigravida women experiencing a low-risk pregnancy choose the place in which they plan to give birth in New Zealand. Otago Polytechnic.

Huff, D. L. (2003). Parameter Estimation in the Huff Model. ArcUser, 34-36. Retrieved from http://uat.esri.bi/news/arcuser/1003/files/huff.pdf 
Huff, D., \& McCallum, B. M. (2008). Calibrating the Huff Model Using ArcGIS Business Analyst. Redlands.

Hunt, S. D., Sparkman Jr., R. D., \& Wilcox, J. B. (1982). The Pretest in Survey Research: Issues and Preliminary Findings. Journal of Marketing Research (JMR), 19(2), 269-273.

Ibbotson, L. (2014a, July 22). 1400 new houses for Wanaka. The Otago Daily Times,. Dunedin. Retrieved from http://www.nzherald.co.nz/business/news/article.cfm?c_id=3\&objectid=111907 52

Ibbotson, L. (2014b, July 25). Council votes for plan change. The Otago Daily Times. Dunedin.

Illich, I. (1976). Medical nemesis: the expropriation of health. New York: Pantheon Books.

Joseph, A. E., \& Phillips, D. R. (1984). Accessibility and Utilization: Geographical Perspectives on Health Care Delivery. SAGE. Retrieved from $\mathrm{http} / / /$ books.google.co.nz/books/about/Accessibility_and_Utilization.html?id=n Ttu_weDou0C\&pgis $=1$

Kara, F., \& Istvan Oliver, E. (2013). Accessibility Of Health Care Institutions: A Case Study by Using GIS. International Journal of Scientific Knowledge: Computing and Information Technology, 3(4), 16-27. Retrieved from http://ijsk.org/ijsk-volume-3-issue-1-2-3-4.html

Katz-Rothman, B. (1991). In Labor: Women and Power in the Birthplace. New York: W W Norton \& Company Incorporated.

Katz-Rothman, B. (2014). Pregnancy, birth and risk: an introduction. Health, Risk \& Society, 16(1), 1-6. doi:10.1080/13698575.2013.876191

Kearns, R. A. (1993). Place and Health: Towards a Reformed Medical Geography. The Professional Geographer, 45(2), 139-147. doi:10.1111/j.00330124.1993.00139.x

King, L. J. (1984). Central Place Theory. Beverley Hills: Sage Publications.

Kirby, R. S. (2011). Perinatal outcomes and nativity: does place of birth really influence infant health? Birth (Berkeley, Calif.), 38(4), 354-6. doi:10.1111/j.1523-536X.2011.00505.x

Kirkham, M., \& Jowitt, M. (2012). Optimising endorphins. The Practising Midwife, 15(10), 33-35. Retrieved from http://www.ingentaconnect.com/content/mesl/tpm/2012/00000015/00000010/ar t00010 
Knight, V. A., Williams, J. E., \& Reynolds, I. (2011, August 26). Modelling patient choice in healthcare systems: development and application of a discrete event simulation with agent-based decision making. doi:10.1057/jos.2011.21

Kozyniak, A. M. (1982). Health Care Access: A Geographic Overview. Massey University.

Kurland, K. S., \& Gorr, W. L. (2014). GIS Tutorial for Health (5th ed.). Redlands: Esri Press. Retrieved from http:/www.amazon.com/Tutorial-Health-fifthKristen-

Kurland/dp/1589483723/ref=sr_1_2?s=books\&ie=UTF8\&qid=1415180813\&sr $=1-2$

Lavender, T., \& Chapple, J. (2005). How women choose where to give birth. The Practising Midwife, 8(7), 10-5. Retrieved from http://www.ncbi.nlm.nih.gov/pubmed/16044988

Longest, B. B. (1971). A Test of Reilly's Law of Retail Gravitation for Northeast Georgia Hospitals. Inquiry, 8(4), 63-65 CR - Copyright \&\#169; 1971 Excellus Health P. doi:10.2307/29770683

Longhurst, R. (2008). Maternities: Gender, Bodies and Space. New York: Routledge.

Longley, P. A., Goodchild, M., Maguire, D. J., \& Rhind, D. W. (2011). Geographic Information Systems and Science. (P. A. Longley, M. Goodchild, D. J. Maguire, \& D. W. Rhind, Eds.) (3rd ed.). Hoboken: Wiley. Retrieved from http://au.wiley.com/WileyCDA/WileyTitle/productCd-EHEP001475.html

Lovett, A., Sünnenberg, G., \& Haynes, R. (2004). Using GIS to Assess Accessibility to Primary Healthcare Services. In GIS in Public Health Practice. CRC Press. doi:doi:10.1201/9780203720349.ch12

Lowe, J. M., \& Sen, A. (2006). Gravity Model Applications in Health Planning: Analysis of an Urban Hospital Market. Journal of Regional Science, 36(3), 437-461. doi:10.1111/j.1467-9787.1996.tb01111.x

Luo, J. (2014). Integrating the Huff Model and Floating Catchment Area Methods to Analyze Spatial Access to Healthcare Services. Transactions in GIS, 18(3), 436-448. doi:10.1111/tgis. 12096

Luo, W., \& Wang, F. (2003). Measures of spatial accessibility to health care in a GIS environment: synthesis and a case study in the Chicago region. Environment and Planning B: Planning and Design, 30(6), 865-884. doi:10.1068/b29120

Madi, B. C., \& Crow, R. (2003). A qualitative study of information about available options for childbirth venue and pregnant women's preference for a place of delivery. Midwifery, 19(4), 328-336. doi:10.1016/S0266-6138(03)00042-1 
Massey, D. S., \& Tourangeau, R. (2012). Where Do We Go from Here? Nonresponse and Social Measurement. The ANNALS of the American Academy of Political and Social Science, 645(1), 222-236. doi:10.1177/0002716212464191

McGuirk, M. A., \& Porell, F. W. (1984). Spatial Patterns of Hospital Utilization: The Impact of Distance and Time. Inquiry, 21(1), 84-95. doi: $10.2307 / 29771616$

McKinnon, M. (2012). Otago places - Wānaka district. In Te Ara - the Encyclopedia of New Zealand. Wellington: Ministry for Culture and Heritage Te Manatu Taonga. Retrieved from http://www.teara.govt.nz/en/photograph/22891/crownrange-road-summit

Miller, S., \& Skinner, J. (2012). Are First-Time Mothers Who Plan Home Birth More Likely to Receive Evidence-Based Care? A Comparative Study of Home and Hospital Care Provided by the Same Midwives. Birth, 39(2), 135-144. Retrieved from http://doi.wiley.com/10.1111/j.1523-536X.2012.00534.x

Ministry of Health. Maternity Services Notice Pursuant to Section 88 of the New Zealand Public Health \& Disability Act 2000. (M. of Health, Ed.) (2002). Wellington: Ministry of Health. Retrieved from http://www.nzhis.govt.nz/documentation/ethnicity/index.html

Ministry of Health. (2011). Rural Health. Retrieved June 10, 2014, from http://www.health.govt.nz/our-work/populations/rural-health

Ministry of Health. (2012). Report on Maternity, 2010. Wellington. Retrieved from http://www.health.govt.nz/publication/report-maternity-2010

Ministry of Health. (2013). Maternity Tables 2013. Wellington.

Ministry of Health. (2014a). 2014/15 Service Coverage Schedule. Wellington.

Ministry of Health. (2014b). Care Closer to Home. Wellington: Ministry of Health.

Ministry of Health. (2014c). Maternity Tables 2011. Wellington. Retrieved from http://www.health.govt.nz/publication/maternity-tables-2011

Ministry of Health, \& DHBNZ. (2011). DHB-funded Secondary and Tertiary Maternity Services and Facilities, tier two service specification. Wellington.

Mottram, L. (2008). First-time expectant fathers and their influence on decision making regarding choice for place of birth. MIDIRS Midwifery Digest, 18(4), 582-589.

National Institute for Health and Clinical Excellence. (2014). CG190: Intrapartum Care: Care of healthy women and their babies during childbirth. 
National Perinatal Epidemiology Unit (NPEU). (2014). Birthplace in England Research programme. Retrieved September 3, 2014, from https://www.npeu.ox.ac.uk/birthplace

New Zealand Ministry of Health. (2012). District Health Boards: Location boundaries (map). Retrieved April 25, 2014, from http://www.health.govt.nz/new-zealand-health-system/key-health-sectororganisations-and-people/district-health-boards/location-boundaries-map

Office of the Privacy Commissioner. Health Information Privacy Code 1994 (revised edition: 2008) (2008). Auckland.

Overgaard, C., Fenger-Grøn, M., \& Sandall, J. (2012). Freestanding midwifery units versus obstetric units: does the effect of place of birth differ with level of social disadvantage? BMC Public Health, 12(1), 478. doi:10.1186/1471-2458-12-478

Papps, E., \& Olssen, M. (1997). Doctoring Childbirth and Regulating Midwifery in New Zealand: A Foucauldian Perspective. Palmerston North: Dunmore Press.

Parker, E. B., \& Campbell, J. L. (1998). Measuring access to primary medical care: some examples of the use of geographical information systems. Health Place, 4(2), 183-193. Retrieved from http://www.ncbi.nlm.nih.gov/pubmed/10671022

Parkinson, A. (2013, October 9). Lumsden loses its maternity centre. The Southland Times. Invercargill. Retrieved from http://www.stuff.co.nz/southlandtimes/news/9259016/Lumsden-loses-its-maternity-centre

Patterson, J. A. (2009). A Time of Travelling Hopefully: a Mixed Methods Study of Decision Making by Women and Midwives about Maternity Transfers in Rural Aotearoa, New Zealand. Victoria University of Wellington. Retrieved from http://researcharchive.vuw.ac.nz/handle/10063/1028

Pearce, J., Witten, K., \& Bartie, P. (2006). Neighbourhoods and health: a GIS approach to measuring community resource accessibility. Journal of Epidemiology and Community Health, 60(5), 389-95. doi:10.1136/jech.2005.043281

Penchansky, R., \& Thomas, J. W. (1981). The concept of access: definition and relationship to consumer satisfaction. Medical Care, 19(2), 127-40. Retrieved from http://www.ncbi.nlm.nih.gov/pubmed/7206846

Pilkington, H., Blondel, B., Carayol, M., Breart, G., \& Zeitlin, J. (2008). Impact of maternity unit closures on access to obstetrical care: The French experience between 1998 and 2003. Social Science \&amp; Medicine, 67(10), 1521-1529. doi:10.1016/j.socscimed.2008.07.021

Pilkington, H., Blondel, B., Drewniak, N., \& Zeitlin, J. (2012). Choice in maternity care: associations with unit supply, geographic accessibility and user characteristics. International Journal of Health Geographics, 11, 35. doi:10.1186/1476-072X-11-35 
Pilkington, H., Blondel, B., Papiernik, E., Cuttini, M., Charreire, H., Maier, R. F., ... Zeitlin, J. (2010). Distribution of maternity units and spatial access to specialised care for women delivering before 32 weeks of gestation in Europe. Health \&amp; Place, 16(3), 531-538. doi:10.1016/j.healthplace.2009.12.011

Pitchforth, E., van Teijlingen, E., Watson, V., Tucker, J., Kiger, A., Ireland, J., ... Ryan, M. (2009). "Choice" and place of delivery: a qualitative study of women in remote and rural Scotland. Quality \& Safety In Health Care, 18(1), 42-48. doi:10.1136/qshc.2007.023572

Pitchforth, E., Watson, V., Tucker, J., Ryan, M., van Teijlingen, E., Farmer, J., ... Bryers, H. (2008). Models of intrapartum care and women's trade-offs in remote and rural Scotland: a mixed-methods study. BJOG: An International Journal of Obstetrics and Gynaecology, 115(5), 560-9. doi:10.1111/j.14710528.2007.01516.x

Pratt, M., Moore, H., \& Craig, T. (2014). Solving a Public Health Problem Using Location-Allocation. ArcUser, (Summer), 56-59.

Prescott, H. (2009). birth-place. Feminist Review, 93(93), 101-108 CR - Copyright \&\#169; 2009 Palgrave Macmi. doi:10.1057/fr.2009.31

Ramer, S. L. (2005). Site-ation pearl growing: methods and librarianship history and theory. Journal of the Medical Library Association: JMLA, 93(3), 397-400. Retrieved from http://www.pubmedcentral.nih.gov/articlerender.fcgi? $\operatorname{artid}=1175807 \&$ tool=pmc entrez\&rendertype $=$ abstract

Rodrigue, J.-P. (2014). The Geography of Transport Systems. Retrieved April 9, 2014, from https://people.hofstra.edu/geotrans/eng/methods/reillylaw.html

Rooväli, L., \& Kiivet, R. A. (2006). Geographical variations in hospital use in Estonia. Health \& Place, 12(2), 195-202. doi:10.1016/j.healthplace.2004.12.001

Schlosser, R. W., Wendt, O., Bhavnani, S., \& Nail-Chiwetalu, B. (2006). Use of information-seeking strategies for developing systematic reviews and engaging in evidence-based practice: the application of traditional and comprehensive Pearl Growing. A review. International Journal of Language \& Communication Disorders / Royal College of Speech \& Language Therapists, 41(5), 567-82. doi:10.1080/13682820600742190

Sethna, C., \& Doull, M. (2013). Spatial disparities and travel to freestanding abortion clinics in Canada. Women's Studies International Forum, 38, 52-62. Retrieved from http://www.sciencedirect.com/science/article/pii/S0277539513000186

Skinner, J. P. (2005). Risk and the Midwife: A descriptive and interpretive examination of the referral for obstetric consultation practices and attitudes of 
New Zealand midwives. Victoria University, Wellington. Retrieved from http://researcharchive.vuw.ac.nz/handle/10063/56

Smythe, E. (1998). Being safe in childbirth: a hermeneutic interpretation of the narratives of women and practitioners: a thesis presented in fulfilment of the requirements for the degree of Doctor of Philosophy. Massey University.

Southern District Health Board. (2014). Maternity Facility Statistics: Queen Mary Maternity SDHB. Dunedin.

StataCorp. (2014). Stata. College Station: StataCorp.

Statistics New Zealand. (n.d.). 2013 Census district health board tables. Retrieved May 28, 2014, from http://www.stats.govt.nz/Census/2013-census/datatables/dhb-tables.aspx

Statistics New Zealand. (2014a). Core Questions Module - Statistics New Zealand. Retrieved June 17, 2013, from http://www.stats.govt.nz/surveys_and_methods/methods/survey-design-datacollection/core-questions-module.aspx

Statistics New Zealand. (2014b). Quick Stats About Invercargill City. Retrieved December 1, 2014, from http://www.stats.govt.nz/Census/2006CensusHomePage/QuickStats/AboutAPla ce/SnapShot.aspx $?$ tab $=$ Culturaldiversity\&id $=2000075$

Statistics New Zealand. (2014c). QuickStats About Queenstown-Lakes District Statistics New Zealand. Retrieved November 5, 2014, from http://www.stats.govt.nz/Census/2006CensusHomePage/QuickStats/AboutAPla ce/SnapShot.aspx?id=2000070

Statistics New Zealand. (2014d). QuickStats About Wanaka. Retrieved June 29, 2014 ,

from http://www.stats.govt.nz/Census/2006CensusHomePage/QuickStats/AboutAPla ce/SnapShot.aspx?id=3608800

Van Teijlingen, E. R., \& Pitchforth, E. (2010). Rural maternity care: can we learn from Wal-Mart? Health \& Place, 16(2), 359-64. Retrieved from http://dx.doi.org/10.1016/j.healthplace.2009.11.007

Wang, F. (2012). Measurement, Optimization, and Impact of Health Care Accessibility: A Methodological Review. Annals of the Association of American Geographers. Association of American Geographers, 102(5), 11041112. doi:10.1080/00045608.2012.657146

Weisman, L. K. (1992). Discrimination by Design: A Feminist Critique of the ManMade Environment. Urbana: University of Illinois Press.

Whyte, S., \& Hyndman, G. (2011, December 5). Tuatapere to lose maternity home. The Southland Times. Invercargill. Retrieved from 
http://www.stuff.co.nz/southland-times/news/6084737/Tuatapere-to-losematernity-home

Williams, M. (2008). Google Maps Geocoding API Script. Blackpool: Blackpool Community Church Javascript Team. Retrieved from http://econym.org.uk/gmap/

Zola, I. K. (1972). Medicine As An Institution of Social Control. The Sociological Review, 20(4), 487-504. doi:10.1111/j.1467-954X.1972.tb00220.x 


\section{Appendices}

\section{Appendix 1- Information Sheet \& Instructions}

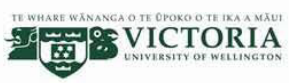

Participant Information Sheet for "Travel Patterns of Women Giving Birth in New Zealand"

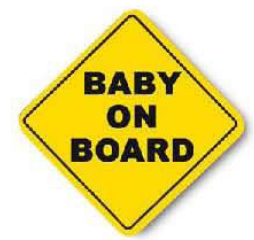

My name is Pauline Dawson. I am a registered midwife and a Masters student at the Graduate School of Nursing, Midwifery \& Health, Victoria University of Wellington

As part of my Masters of Midwifery degree, I am undertaking a research project leading to a thesis. I will be examining where women travel to give birth in New Zealand and the factors that influence this decision. This research project has received approval from the Victoria University Human Ethics Committee (Approval \#20256).

I am inviting women giving birth in the Southern District Health Board region during a 3 month period in 2014 to participate in this study. Participants will be asked to complete a short questionnaire about their choice of birth place. It is envisaged that the questionnaire will take less than 5 minutes to complete and can be returned to the maternity facility during your stay or to your LMC. You will find boxes at the facility marked with a "Baby on Board" symbol (see above) where you can drop your questionnaire off. Consent to participate in this study is implied by completion of this questionnaire.

Responses will form the basis of my research project and will be put into a written report on an anonymous basis. It will not be possible for you to be identified personally. Specifically, your address information will be geocoded to a general geographical region to prevent any possible identification.

All material collected will be kept confidential. No other person besides me and my supervisor $\mathrm{Dr}$ Joan Skinner will see the questionnaires. The thesis will be submitted for marking to the Graduate School of Nursing, Midwifery \& Health and deposited in the University Library. It is intended that one or more articles will be submitted for publication in scholarly journals and presentations may be given about this project. Questionnaires will be destroyed two years after the end of the project.

If you have any further questions or would like to receive further information, please contact me at: or email: or my supervisor Dr Joan Skinner at the Graduate School of Nursing, Midwifery \& Health at Victoria University phone: You may also contact us if you are interested in obtaining a copy of the study results when the project is complete.

Thank you for your participation.

Pauline Dawson, RM 
Instructions for completing the "Travel Patterns of Women Giving Birth in New

\section{Zealand" questionnaire:}

* Please use Black or Blue pen to complete the questionnaire

* Read all the questions thoroughly

* When completing Alpha Numeric data collection boxes for optimum accuracy, please print in captial letters and use the number formats and avoid contact with the edge of the box.

\begin{tabular}{|l|l|l|l|l|l|l|l|l|l|l|l|l|}
\hline $\mathrm{A}$ & $\mathrm{B}$ & $\mathrm{C}$ & $\mathrm{D}$ & $\mathrm{E}$ & $\mathrm{F}$ & $\mathrm{G}$ & $\mathrm{H}$ & $\mathrm{I}$ & $\mathrm{J}$ & $\mathrm{K}$ & $\mathrm{I}$ & $\mathrm{M}$ \\
\hline $\mathrm{N}$ & $\mathrm{O}$ & $\mathrm{P}$ & $\mathrm{Q}$ & $\mathrm{R}$ & $\mathrm{S}$ & $\mathrm{T}$ & $\mathrm{U}$ & $\mathrm{V}$ & $\mathrm{W}$ & $\mathrm{X}$ & $\mathrm{Y}$ & $\mathrm{Z}$ \\
\hline $\mathrm{y}$ & 1 & 2 & 3 & 4 & 5 & 6 & 7 & 8 & 9 &
\end{tabular}

* When completing a choice question please colour-in the whole box.
$\square 1$
$\square 2$
$\square 3$

* If an error is found after a question has been answered please colour-in the correct answer and place a tick next to the correct answer box.

$\square 1$

$\square 3$

* The free text line is a single line for text entry only and will only accomodate text to the size of the line. Any other comments or written information placed anywhere else will be ignored and not captured

* Some questions require you to draw a line on a $0-100 \%$ scale which helps to see how important a particular reason is to you.

For example

4. Please rate your reasons for choosing your place of birth from most important to least important. Rank as many or few as you want. a. Close to home.

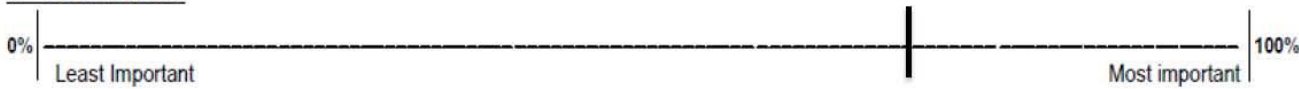

Version 3 March 2014 
$\Gamma$

TE WHARE WÃNANGA O TE OPOKO O TE IKA MĀUI

$59-7 \%$ VICTORIA

Survey No:

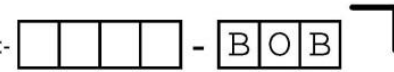

Travel patterns of women giving birth in New Zealand.

1. What is your usual home address?

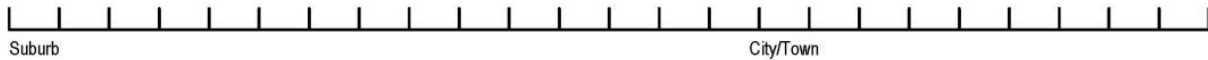

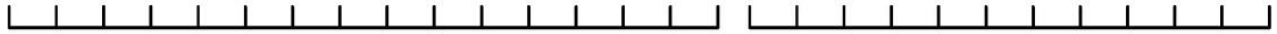

2. Where did you plan to give birth?

$\begin{array}{ll}\text { O Dunedin } & \text { O Alexandra } \\ \text { O Invercargill } & \text { O Oamaru } \\ \text { O Queenstown Lakes } & \text { O Balclutha } \\ \text { O Lumsden } & \text { O Ranfurly } \\ \text { O Winton } & \text { O Gore } \\ \text { O Tuatapere } & \text { O Home }\end{array}$

3. Did you choose this location because you required specialist obstetric care due to complications or risk factors?

$\mathrm{O}$ Yes (if yes go to Question 9.) $\mathrm{O}$ No

4. Please rate your reasons for choosing your place of birth from most important to least important. Rank as many or few as you want.

a. Close to home.

$0 \%$

Least Important $100 \%$

b. Close to family.

$0 \%$

Least Important $100 \%$

c. No other options in my area.

$0 \%$

Least Important $100 \%$

d. Services offered e.g (pain relief, surroundings).

$0 \%$ Least Important $100 \%$

e. The place my midwife /doctor

Most important

f. Where I felt safe.

$0 \%$

g. Other, Please explain below

$0 \%$ Least Important $100 \%$

As you have have identified "Other" please explain:-

5. What number baby is this for you?

L BoB9 $21768 \quad$ Page 1 of $2 \quad$ 27/03/2014 03:44:21 P.M. 
1

6. Where did you actually give birth?

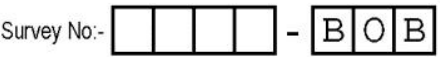
O Dunedin
Alexandra
O Invercargill
O Oamaru
O Queenstown Lakes
Balclutha
O Lumsden
Ranfurly
O Winton
O Gore
O Tuatapere
O Home

7. If you gave birth at a different place than planned, why was that?

Complications in Labour

O Complications with Baby

O Complications before Labour

Required Aditional Pain Relief

O Not applicable

Other Please explain :-

8. How long did it take you to travel from your home to the place of birth?

$\mathrm{O}$ Less than 30 mins

O 2 hours to $2: 59$ minutes

30-59 minutes

$O$ Greater than 3 hours

O 1 hours to $1: 59$ minutes

9. Which age range are you in?
$\mathrm{O}$ less than 24 years old
24-34 years old
35-44 years dd
more than 45 years old

10. Which ethnic group do you most identify with? (Select only one)

O New Zealand European

O Maori

O Samoan

O Cook Island Maori

O Tongan

ONiuean

OChinese

O Indian

Other. such as Dutch, Japanese, Tokelauan. Please state:

11. What is the highest qualification you have completed? (put a mark in one box only)

O No secondary school qualifications

O Secondary School

National certificate, diploma or similar

University or tertiary institute undergraduate degree

University or tertiary institute postgraduate qualification

12. Before Tax or anything else is taken out (eg. student loan, ACC), which of the following best describes your approximate household income range, from all sources, over the last 12 months?

Ozero

O $\$ 50,001-\$ 70,000$

$\mathrm{O} \$ 1-\$ 10,000$

O $\$ 70,001-\$ 100,000$

O $\$ 10,001-\$ 30,000$

O $\$ 100,001$ or more

$\mathrm{O} \$ 30,001-\$ 50,000$

Do not want to answer

That is the end! Thank you very much for helping us with this survey.

Goodbye!

— BoB9 $21768 \quad$ Page 2 of $2 \quad$ 27/03/2014 03:44:21 P.M




\begin{tabular}{l|l}
\hline TO & Pauline Dawson \\
\hline COPY TO & Joan Skinner \\
\hline FROM & Dr Allison Kirkman, Convener, Human Ethics Committee \\
\hline
\end{tabular}

\begin{tabular}{l|l}
\hline DATE & 14 November 2013 \\
\hline PAGES & 1 \\
\hline \multicolumn{2}{|l|}{$\begin{array}{l}\text { Ethics Approval: 20256 } \\
\text { Travel Patterns of Women Giving Birth in New Zealand }\end{array}$} \\
\hline
\end{tabular}

Thank you for your application for ethical approval, which has now been considered by the Standing Committee of the Human Ethics Committee.

Your application has been approved from the above date and this approval continues until 31 December 2014. If your data collection is not completed by this date you should apply to the Human Ethics Committee for an extension to this approval.

Best wishes with the research.

Allison Kirkman

Human Ethics Committee

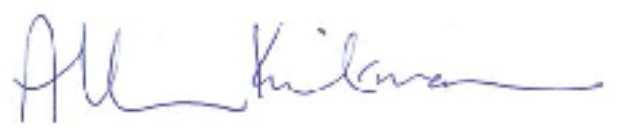




\section{Health Research South}

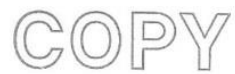

$22 / 01 / 2014$

Project ID 00976

Consultant Michael Stitely

$\mathrm{DPH}$

Dear Michael

REF: Travel patterns of Women giving birth in New Zealand

I am writing on behalf of Health Research South to confirm that the project mentioned above has been granted approval to proceed.

According to our records:

This project is due to commence on: 22/01/2014

It is due to be completed by: $1 / 12 / 2014$

If you have any questions with regards to this process, please contact me quoting the project ID shown above.

Yours sincerely

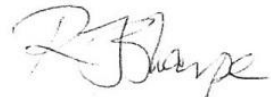

Ruth Sharpe

CLINICAL RESEARCH AdVISOR

cC.: Elaine Chisnall, Southern DHB

Pauline Dawson, Women's and Children's Health, DPH

Health Research South

Health Research South

PO Box 56, Dunedin 9054

Ruth Sharpe, Clinical Research Advisor, Ph: 034709032 (Hosp 9032); Ruth.Sharpe $@$ otago.ac.nz 


\title{
Appendix 5 - Scientific Peer Review (District Health Board)
}

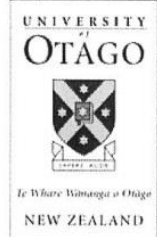

Department of Women's and Children's Health

Te Tari Hauora Wāhine me te Tamariki

Clinical Genetics Research Group

\section{SCIENTIFIC PEER REVIEW: Letter to researcher to inform of results}

\author{
Date 5 December 2013 \\ Dear Pauline
}

Re Scientific Peer Review

Please find attached your peer review for the following project.

Title: Baby on board: Travel patterns of women giving birth in New Zealand

Investigator: Pauline Dawson

Department: WCH

Your project is considered to have

- satisfactory peer review

Yours sincerely

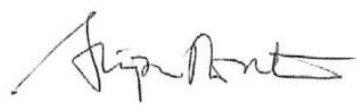

Stephen Robertson

Chairperson, Scientific Peer Review Committee

Department of Women's and Children's Health

\author{
Department of Women's \& Children's Iealth, Clinical Genetics Researeh Group. \\ Dunedin School of Medicine, University of Otago. \\ PO Box 913, Dunedin 9054, New Zealand \\ Tel/Fax: $+643+799746$ \\ DUNEDIN • CHRISTCHURCH • WELLINGTON•AUCKLAND
}




\section{Appendix 6 - Ngāi Tahu Māori Consultation}

\section{Ngāi Tahu Research Consultation Committee TE KOMITI RAKAHAU KI KAI TAHU}

Tuesday, 29 October 2013.

Associate Professor Michael Stitely,

Dunedin School of Medicine - Obsterics and Gynaecology,

DUNEDIN.

Tēnā Koe Associate Professor Michael Stitely,

"Where do women travel in New Zealand to give birth?"

The Ngāi Tahu Research Consultation Committee (The Committee) met on Tuesday, 29 October 2013 to discuss your research proposition.

By way of introduction, this response from The Committee is provided as part of the Memorandum of Understanding between Te Rūnanga o Ngāi Tahu and the University. In the statement of principles of the memorandum it states "Ngāi Tahu acknowledges that the

consultation process outline in this policy provides no power of veto by Ngāi Tahu to research undertaken at the University of Otago". As such, this response is not "approval" or "mandate" for the research, rather it is a mandated response from a Ngāi Tahu appointed committee. This process is part of a number of requirements for researchers to undertake and does not cover other issues relating to ethics, including methodology they are separate requirements with other committees, for example the Human Ethics Committee, etc.

Within the context of the Policy for Research Consultation with Mãori, the Committee base consultation on that defined by Justice McGechan:

"Consultation does not mean negotiation or agreement. It means: setting out a proposal not fully decided upon; adequately informing a party about relevant information upon which the proposal is based; listening to what the others have to say with an open mind (in that there is room to be persuaded against the proposal); undertaking that task in a genuine and not cosmetic manner. Reaching a decision that may or may not alter the original proposal."

The Committee notes this is Southern District Health Board research.

The Committee considers the research to be of importance to Māori health.

The Committee notes and commends that ethnicity data is to be collected as part of the research project and recommends the use of the questions on self-identified ethnicity and descent, these questions are contained in the latest census.

The Committee suggests including in the research team a researcher with expertise in analysing and interpreting data by ethnicity.

The Committee suggests dissemination of the research findings to Māori health organisations regarding this study.

We wish you every success in your research and The Committee also requests a copy of the research findings.

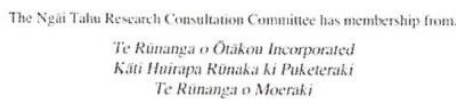




\section{Ngāi Tahu Research Consultation Committee TE KOMITI RAKAHAU KI KAI TAHU}

This letter of suggestion, recommendation and advice is current for an 18 month period from Tuesday, 29 October 2013 to 17 April 2015.

Nāhaku noa, nā

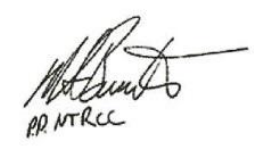

Mark Brunton

Kaiwhakahaere Rangahau Māori

Research Manager Māori

Research Division

Te Whare Wānanga o Otāgo

$\mathrm{Ph}:+6434798738$

Email: mark.brunton@otago.ac.nz

Web: www.otago.ac.nz 